ICTD Working Paper 126

\section{Co-Financing Community-Driven Development Through Informal Taxation: Experimental Evidence from South-Central Somalia}

Vanessa van den Boogaard and Fabrizio Santoro

September 2021 
Co-Financing Community-Driven Development Through Informal Taxation: Experimental Evidence from South-Central Somalia

Vanessa van den Boogaard and Fabrizio Santoro

ICTD WORKING PAPER 126

First published by the Institute of Development Studies in September 2021

(C) Institute of Development Studies 2021

ISBN: [978-1-78118-850-7]

DOI: $10.19088 /$ ICTD.2021.016

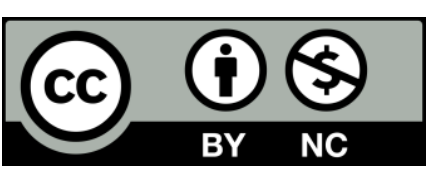

This is an Open Access paper distributed under the terms of the Creative Commons Attribution Non Commercial 4.0

International license, which permits downloading and sharing provided the original authors and source are credited - but the work is not used for commercial purposes. http://creativecommons.org/licenses/by-nc/4.0/legalcode

Available from:

The International Centre for Tax and Development at the Institute of Development Studies, Brighton BN1 9RE, UK

Tel: +44(0) 1273606261

Email: info@ictd.ac

Web: www.ictd.ac/publication

Twitter: @ICTDTax

Facebook: www.facebook.com/ICTDtax

IDS is a charitable company limited by guarantee and registered in England

Charity Registration Number 306371

Charitable Company Number 877338 


\title{
Co-Financing Community-Driven Development Through Informal Taxation: Experimental Evidence from South-Central Somalia
}

\author{
Vanessa van den Boogaard and Fabrizio Santoro
}

\section{Summary}

Community contributions are often required as part of community-driven development (CDD) programmes, with payment encouraged through matching grants. However, little remains known about the impact of matching grants, or the implications of requiring community contributions in order for communities to receive development funding.

This paper describes research where we partner with two non-governmental organisations (NGOs) - one international and one Somali - and undertake a randomised control trial of a CDD matching grant programme designed to incentivise informal contributions for local public goods in Gedo region in south-central Somalia. We rely on household survey data collected from 1,297 respondents in 31 treatment and 31 control communities, as well as surveys of village leaders and data on informal contributions from the mobile money platform used by community leaders to collect revenue.

Two key findings emerge. First, our research shows that working with communities and incentivising informal revenue generation can be an effective way to deliver public goods and to support citizens and communities. Second, building on research exploring the potential for development interventions to spur virtuous or adverse cycles of governance, we show that development partners may work directly with community leaders and informal taxing institutions without necessarily undermining - and indeed perhaps strengthening - state legitimacy and related ongoing processes of statebuilding in the country. Indeed, despite playing no direct role in the matching grant programme, taxpayer perceptions of the legitimacy of the local government improved as a result of the programme. These findings deepen our understanding of how community contributions may be incentivised through matching grant programmes, and how they may contribute to CDD and public goods provision in a context of weak institutional capacity.

Keywords: informal taxation; informal revenue generation; community contributions; matching grants; community-driven development; experimental methods; Somalia.

Vanessa van den Boogaard is a Research Fellow at the International Centre for Tax and Development, where she co-leads the research programme on informality and taxation.

Fabrizio Santoro is a Postdoctoral Fellow at the Institute of Development Studies and at the International Centre for Tax and Development. 


\section{Contents}

Summary 3

Acknowledgements

Acronyms $\quad 5$

$1 \quad$ Introduction 6

2 Background: informal revenue generation and CDD in south-central Somalia

$\begin{array}{lll}3 & \text { Research design } & 13\end{array}$

4 Data 16

$5 \quad$ Main results $\quad 17$

5.1 Effects on informal contributions to public goods 18

$\begin{array}{lll}5.2 & \text { Effects on public outcomes } & 20\end{array}$

5.3 Effects on perceptions of governance actors 23

6 Discussion: co-financing CDD through informal taxes 27

$\begin{array}{lll}6.1 & \text { Effectiveness of co-financing CDD } & 27\end{array}$

6.2 Spillover effects for state and non-state actors 30

$7 \quad$ Implications for development partners and the Somali state 32

8 Conclusions $\quad 38$

$\begin{array}{lll}\text { Appendix A DIALOGUE programme } & 40\end{array}$

Appendix B Community contributions and matching grants 42

Appendix C Balance and attrition tables $\quad 44$

$\begin{array}{lll}\text { Appendix D } & \text { Descriptive data, settlements } & 47\end{array}$

$\begin{array}{lll}\text { Appendix E } & \text { Context of study } & 48\end{array}$

$\begin{array}{lll}\text { Appendix } F & \text { DIALOGUE impact on project outcomes } & 49\end{array}$

Appendix G DIALOGUE impact on engagement 51

$\begin{array}{lll}\text { Appendix H } & \text { DIALOGUE impact on performance } & 52\end{array}$

Appendix I Informal tax payment and accountability actions 53

References

Tables

Table 1

Table 2

Table 3

Table 4

Table 5

Table 6

DIALOGUE impact on new community development projects in last year 19

DIALOGUE impact on IRG (sub-categories) 20

Dissatisfaction with new community development projects 21

DIALOGUE impact on respondents' answerability actions 21

DIALOGUE impact on inclusive decision-making 22

DIALOGUE impact on frequency of information-sharing about new project

Table 7 Impact on actors' legitimacy

Figure 2 Likelihood (left) and incidence (right) of informal contributions to the DIALOGUE programme by $\mathrm{HH}$ wealth quintiles 


\section{Acknowledgements}

We are grateful to the Somalia Stability Fund for funding this research, and to the Danish Refugee Council (DRC) for collaborating on this project. We are particularly grateful to Ivanoe Fugali and Mohamed Mohamud Hussein AP for their partnership and for showing great enthusiasm for the work. We are likewise grateful to all the staff at the DRC Dooloow office and the DRC Somalia national security team for facilitating data collection and welcoming us to Gedo. The research would not have been possible without an excellent team of research enumerators in Gedo region. For security purposes, the names of DRC staff and research enumerators are not shared, though this certainly does not diminish our gratitude to them. We are particularly thankful to the research participants who spoke with us and our research team during the course of this research.

The paper was much improved by useful suggestions from readers of early versions of the paper, including Mick Moore, Tanya Bandula Irwin, Mohamed Mohamud Hussein AP, Ivanoe Fugali, Ahmed Hashi, Ameet Morjaria, Gustavo Bobonis, Gael Raballand, Roel Dom, Justine Knebelmann, Najibullah Nor Isak, the panel participants of the 2021 American Economic Association conference, the Centre for the Study of African Economies conference, and the International Studies Association conference. We are grateful to our exceptional ICTD colleagues who provided useful feedback during a research seminar, and to Odd-Helge Fjeldstad and Ingrid Hoem Sjursen for giving us the opportunity to get additional excellent feedback as part of the CMI Tax and Development seminar series. Finally, we thank the anonymous ICTD reviewers who greatly improved our work and the ICTD publications team and copy-editors for their support.

\section{Acronyms}

$\begin{array}{ll}\text { CDD } & \text { Community-driven development } \\ \text { CDR } & \begin{array}{l}\text { Community-driven reconstruction } \\ \text { DIALOGUE }\end{array} \\ & \begin{array}{l}\text { Develop Informed and Accountable Local Governance through User } \\ \text { Empowerment }\end{array} \\ \text { DRC } & \text { Danish Refugee Council } \\ \text { FGS } & \text { Federal Government of Somalia } \\ \text { HH } & \text { Household } \\ \text { IDP } & \text { Internally-displaced person } \\ \text { IRG } & \text { Informal revenue generation } \\ \text { LPM } & \text { Linear probability model } \\ \text { NGO } & \text { Non-governmental organisation } \\ \text { TFG } & \text { Transitional Federal Government }\end{array}$




\section{Introduction}

Community-driven development (CDD) has long been embraced by international development partners as a means of delivering public goods and strengthening social capital and cohesion (White et al. 2018), particularly in fragile contexts (Fearon et al. 2009; Strand et al. 2003; World Bank 2015). By one estimate, the World Bank alone lends more than US\$2 billion a year in support of CDD programmes (Mansuri and Rao 2004). To receive external support, CDD projects often require co-financing from communities through informal taxes non-market payments that are not required or defined by state law, and are enforced outside the state legal system. Co-financing is often incentivised through CDD grants, with the requirement for informal taxes largely justified based on the belief that they will create a greater sense of ownership over projects and increase their sustainability (Aga et al. 2018; Carvalho and White 2004; Rawlings et al. 2004).

As a growing body of evidence shows that informal taxation is regressive (Olken and Singhal 2011; Paler et al. 2017; van den Boogaard et al. 2019; van den Boogaard and Santoro 2021; Walker 2018), the benefits of local co-financing should outweigh the negative distributional impacts. However, and despite being widely embraced by development partners and donors and incorporated into CDD programmes, there is limited evidence about the impact of cofinancing requirements (Tendler 2000). As evidence suggests that CDD programmes build on rather than build social capital (Isham and Kähkönen 2002; Vajja and White 2008), it is unclear whether CDD programmes can incentivise informal revenue generation and local collective action. At the same time, though it is often assumed that matching grant programmes requiring community contributions will lead to more positive public goods outcomes than external aid alone, there is little evidence of this outcome in practice. Reviews of CDD programmes and meta-analyses often point to negative outcomes and the risk of elite capture (Carrick-Hagenbarth 2016; Ensminger 2017; Hedlund et al. 2013; Humphreys et al. 2012; Kumar and Corbridge 2002; McCarthy et al. 2016; Mosse 2005; Vajja and White 2008; Van Domelen 2003; White 1999). Indeed, it is plausible that local revenue requirements lead to coercive revenue-raising tactics, with revenue used primarily to benefit local elites.

Beyond the effectiveness of co-financed CDD programmes, little is known about the impact of requiring co-financing through informal community contributions for state and non-state governance actors. It is not clear whether co-financing requirements serve to 'crowd out' other forms of formal and informal revenue-raising, and whether working with informal taxing institutions outside the state negatively affects state legitimacy. While there is a broader literature on the ways in which non-state service provision (e.g. Cammett and MacLean 2014) and aid (e.g. Baldwin and Winters 2018, 2020; Montinola et al. 2020) are likely to affect state and state-citizen relationships, there has been more limited exploration of the impact of development partners bypassing the state through CDD and requiring informal taxation as a condition of receiving aid (Parker and Serrano 2000; Tendler and Serrano 1999).

We explore these research gaps through a randomised control trial of a CDD programme in Gedo region in south-central Somalia, which made use of matching grants to incentivise informal contributions for local public goods. This CDD programme, known as the DIALOGUE (Develop Informed and Accountable Local Governance through User Empowerment) programme, was implemented by two NGOs - one international and one Somali. It involved two interventions: a grant, matching or surpassing revenue raised informally by communities, and a set of measures aimed at increasing oversight over communities' management of informal revenue, including using an online contribution and payment tracking platform. We capture the views of citizens, local leaders and objective assessments of the programme's impact across communities that received these 
interventions (treatment communities) and those that did not (control communities), before and after the programme implementation. Through this, we offer an important empirical perspective on the impacts of a CDD programme in a challenging context - contributing to limited knowledge about co-financing development, and offering a relatively rare assessment of aid in Somalia. ${ }^{1}$

Two key sets of findings emerge. First, we find that the CDD programme in Gedo region was effective in both incentivising informal revenue generation and in delivering better quality public goods outcomes. Treatment communities were more likely than control communities to undertake a new development project and to raise new informal revenue to finance public goods. They were also more likely to be satisfied with the public goods outcomes and to perceive greater fiscal reciprocity of informal contributions, supported by more positive objective assessments of the new community development projects. These findings are positive, somewhat surprisingly given the cited risks of elite capture. We believe they can be explained in part through the mechanisms of accountability that were embedded within the transparent and participatory programme design. For example, individuals in treatment communities were more likely to perceive their rights to make demands on local leaders and to play a role in monitoring local revenues and projects. There is also a long history of extensive and relatively effective non-state and informal revenue generation and service delivery in the context of south-central Somalia (see van den Boogaard and Santoro 2021).

Second, we show that the CDD programme with co-financing requirements did not crowd out other forms of revenue-raising, and, importantly, did not undermine perceptions of the legitimacy of the local state and some non-state governance actors. Instead, citizen perceptions of the legitimacy of the local government - their willingness to accept the authority of the local government to levy taxes - increased as a result of the programme. This is striking, particularly as the local government had no direct role in the CDD programme. In exploring the mechanisms through which these outcomes emerge, we find no evidence of false attribution, partial evidence that legitimacy was strengthened through more frequent interactions with leaders, and strong evidence that the positive relationship emerged through shifts in perception of the transparency, trust and performance of local leaders. This indicates that where informal revenue generation helps to finance valued public goods, taxpayers may view state actors as doing their job even if they do not have a direct role in the financing or delivery of public goods.

These findings deepen our understanding of how community contributions may be incentivised through matching grant programmes, and may contribute to CDD and public goods provision in a context of weak state institutional capacity. We thus contribute to literature on the ways in which CDD programmes can increase social capital and local collective action (Casey et al. 2013; Fearon et al. 2009), and on the capacity of externallyfunded programmes to catalyse contributions for public goods (Milner et al. 2016; Montinola et al. 2020). We provide evidence that matching grants may be effectively used to incentivise informal contributions that are enforced through social mechanisms. At the same time, our findings about spillover effects have important implications for our understanding of the relationships and potential complementarity between informal taxing institutions, external financing and the state in a context of weak state institutional capacity (Baldwin 2015, 2019; Baldwin and Holzinger 2019; Cammett and MacLean 2014; Sacks 2012; van den Boogaard 2020b).

Hagmann (2016: 19). notes that: 'The absence of systematic and independent assessments' of aid programmes in Somalia 'makes it difficult to judge their effectiveness and durability'. Ingiriis (2018: $\underline{5}$ ). notes the rarity of research that captures Somali voices: 'Most of those studying Somalia write from the comfort zones of the Ivory Tower in the West, or spend a few months in Kenya when they could not spend a few hours in the Mogadishu airport'. 
As we will explore further, these findings also have important implications for how development partners deliver aid and engage with informal taxing actors outside the state in contexts of weak formal statehood. In Somalia, international development partners and donors often rely on local leaders and informal institutions to deliver services and aid in the region, though are simultaneously invested in strengthening formal state capacity and reach throughout the country. Our evidence suggests that development partners may work with communities and community leaders to co-finance development without necessarily undermining state actors - and potentially actually strengthening the state's legitimacy. Despite these possibilities, we highlight continued and significant risks of requiring cofinancing within CDD programmes, including the important risks of a lack of accountability of local leaders, the exclusion of minorities and sub-populations, the reinforcement of inequitable public goods financing, and the entrenchment of non-universal conceptions of citizenship and rights.

We develop these arguments throughout this paper. In Section 2, we describe the context of CDD and informal taxation in south-central Somalia, identifying key gaps in the literature on CDD with respect to the role and impacts of co-financing requirements. Section 3 explains the experimental research design, while Section 4 details the data upon which the study relies. Section 5 presents the main results of our analysis, exploring the effects of the matching grant programme on informal contributions to public goods, public goods outcomes, formal and informal revenue spillovers, and citizen perceptions of state and nonstate governance actors. Section 6 summarises our key findings, situates them within the broader literature, and reflects on the limitations and external validity of our findings. Section 7 considers the implications for development partners and the state in the region, while flagging important risks of co-financing requirements - despite the positive results that we find in Gedo region. Section 8 concludes and suggests productive new avenues for research based on our findings.

\section{Background: informal revenue generation and CDD in south-central Somalia}

At less than 3 per cent in 2018 Somalia has the lowest tax-to-GDP ratio in the world, and has long faced challenges of weak centralised authority and capacity (Raballand and Knebelmann 2020). In practice, the Federal Government of Somalia (FGS) does not collect taxes outside the capital region, and, even there, collects little apart from customs taxes. Jubbaland state has particularly poor revenue collection capacity, with estimated per capita tax revenue amounting to just US\$6.2 in 2018 (Raballand and Knebelmann 2020). In Gedo region in Jubbaland state, we find that less than a fifth of households pay any formal taxes, with few households paying anything apart from livestock taxes (van den Boogaard and Santoro 2021).

In this context of weak centralised state authority, and building on a history of pre-colonial decentralised authority, south-central Somalia is characterised by a rich network of local governance institutions and community-based informal revenue generation. ${ }^{2}$ Self-reliance, self-help, and hybrid governance between state and non-state authorities, as well as between non-state actors and community leaders, have been 'more the norm than the exception' (Varming 2019: 6; see also Menkhaus 2006, 2014b; Jordan 2016; Hagmann and Hoehne 2009), particularly since the outbreak of civil war in 1988 and the collapse of the

This is in line with a growing body of literature that shows that areas of limited statehood do not necessarily lack institutionalised modes of governance and service provision (Arjona et al. 2015; De Herdt and Titeca 2019; Menkhaus 1998, 2006; Risse 2011; Risse and Stollenwerk 2018: 406). 
state in 1991. Private actors, NGOs and international organisations undertake most service delivery and infrastructure development (Menkhaus 2006: 90, 2014b; Saggiomo 2011; Schäferhoff 2014; UNSC 2018; Varming 2019: 6). ${ }^{3}$ Community leaders and traditional authorities, including clan elders and religious leaders, play an important role in local governance, conflict resolution and local public goods provision, including security and social welfare. ${ }^{4}$ As in many contexts, 'informal taxation is one of the primary ways through which local public goods are financed' (Olken and Singhal 2011: 12). ${ }^{5}$ Capturing a range of informal payments to support the provision of local public goods, security, social welfare and clan governance, in 2017 in Gedo region 71 per cent of households reported paying at least one informal tax or fee in the previous year, with informal contributions representing on average 9.5 per cent of annual household income (van den Boogaard and Santoro 2021). ${ }^{6}$ Among these payments, informal taxes and contributions to support systems of social welfare and social protection and local public goods provision are particularly important. ${ }^{7}$ In the absence of state service provision, households commonly contribute to the maintenance or construction of community development projects, including roads, mosques, public markets, water provision, schools and garbage collection.

Given limited state capacity, a rich and active network of informal institutions and non-state actors, and what is often described as a strong foundation of local collective action (Hammond et al. 2011; Menkhaus 2006, 2014b; Saggiomo 2011; van den Boogaard and Santoro 2021; Varming 2019), ${ }^{8}$ international development partners in Somalia have long relied on development delivery modalities outside the state. ${ }^{9}$ This has often involved working directly with communities and community leaders through CDD programmes, which, as described above, are more broadly embraced by development partners and donors. Motivated by Sen's concepts of capabilities and agency (Nussbaum and Sen 1993), and Ostrom's notions of social capital and collective action (Ostrom 1994), the logic of CDD is

3 As described by a senior official of a telecommunications company, who noted: 'We are doing all the government's work - droughts, rains, IDPs, illnesses. We are the only ones there, so we help. Why? Because of our Somalinimo [Somaliness or sense of nationalism]' (cited in Abshir et al. 2020)

$4 \quad$ In line with political science literature, we define local public goods as goods that are geographically targeted and confer benefits on multiple community members, rather than the stricter economic definition (see e.g. Tiebout 1956). Examples include public schools and water wells.

5 As noted above, informal taxation and revenue generation refers to non-market payments that are not required or defined by state law and are enforced outside the state legal system, with payments that can be made in cash, in kind or through labour contributions (van den Boogaard, 2020b). According to this definition, state or non-state actors may levy informal taxes - what matters is whether the taxes have a formal legal basis and revenue reaches the formal public budget. Informal revenue generation serves as an umbrella concept that captures a range of different informal payments: some look more like user fees to access specific services, some look more like taxes to collectively finance public goods, some finance informal governance institutions and systems of social welfare, some are defined by state law but their revenue doesn't reach state coffers, and some look more like protection payments or extortion for the provision of security, with little choice of whether to pay or not. For a deeper discussion of these conceptual complexities inherent to the concepts of informal taxation and revenue generation, see van den Boogaard (2020b: 51-65) and van den Boogaard et al. (2019).

$6 \quad$ For more explanation of the types of payments and informal taxing institutions captured by this study, see van den Boogaard and Santoro (2021: 18-25). At the same time, many communities are connected with rich transnational networks of diaspora, who likewise engage in and support informal local revenue-raising and contribute to community development projects, often in towns and villages associated with the clan of the diaspora contributors (Hammond et al 2011; Jordan 2016; Menkhaus 2014c)

In line with Cammett and MacLean (2014), we use the term 'social welfare' to refer to health, education and support for poor and disadvantaged groups, while 'social protection' refers to social assistance for the poor and social insurance for the vulnerable (see Getu and Devereux 2013: 3; World Bank 2001: 4).

As described by analyst Rashid Abdi, Somalis have a "higher-than-average "culture of sharing" ... [that] mitigates the worst manifestations of poverty' (R. Abdi, personal communication, 20 March 2020).

$9 \quad$ While CDD programmes are often undertaken with the logic of building social capital, evidence suggests that these programmes may be more effective where there is a pre-existing high level of existing social capital within communities (Vajja and White 2008), as in certain regions in south-central Somalia. For instance, Jordan (2016) shows the feasibility of CDD in Somalia, finding that in the absence of the government, the diaspora and communities have successfully delivered social services through a model similar to CDD. For a broader discussion of CDD and its potential in Somalia see Bakonyi et al. (2015); Bryld and Kamau (2013); DRC and Justice Studio (2015); Dias (2011); Hamming (2011); Hartkorn (2011); World Bank (2009, 2010). 
largely based on the assumed beneficial impact that participation - in planning, selecting and implementing public goods - can have on community trust in public institutions and their own role and responsibilities in these activities (Casey 2018; Mansuri and Rao 2004; Parker and Serrano 2000; White et al. 2018; Wong and Guggenheim 2018). ${ }^{10}$

With CDD programmes, it is common to require communities to contribute in cash or through labour in order to receive external support (Dongier et al. 2002; Rawlings et al. 2004; Tendler 2000; Vajja and White 2008; White et al. 2018; Wong 2012). Under this model, development aid is made contingent on informal contributions, with matching or block grants used to either incentivise or build on local collective action and capacity to mobilise revenue. ${ }^{11}$ As with CDD, co-financing requirements are often justified based on the belief that participation will create a greater sense of ownership over projects (Aga et al. 2018; Carvalho and White 2004; Rawlings et al. 2004), with the potential to spur accountability and empower marginalised populations (Mathie and Cunningham 2003; Peters 2014; Ranganathan 2014). ${ }^{12}$ The expectation of greater accountability parallels the expectation that taxation will lead to greater accountability. The logic is that when citizens are forced to pay taxes they are more likely to make demands on leaders in return for tax payment; leaders that are dependent on citizens for fiscal resources are more likely to be responsive to citizen demands (see e.g. Moore 2004; Prichard 2015). ${ }^{13}$ Aside from these hopes for greater accountability, requirements for community contributions are in line with neoliberal logic that prioritises the cost-effectiveness of projects and the notional fairness of cost-sharing (see e.g. Boesten et al. 2011; Meagher et al. 2014; Peters 2014). ${ }^{14}$ Though empirical evidence is limited, a World Bank guide to CDD notes that 'Mandatory [community] contributions have been shown to be important in building community ownership, helping to ensure that costand service-level choices are not distorted by external grants, and ascertaining through willingness to pay that services respond to real demand - all of which contribute to greater sustainability' (Dongier et al. 2002: 319).

In Somalia, many CDD programmes, including the DRC's DIALOGUE programme - the focus of this study - include requirements for community contributions. As with previous CDD programmes led by the DRC (Hamming 2011), and in line with the logic outlined above, the DIALOGUE matching grant programme was based on the idea that paying for services would make people more likely to monitor outcomes - leading to better public goods outcomes, greater accountability of local revenues and greater responsiveness of local leaders. ${ }^{15}$ While

$10 \mathrm{CDD}$ is often seen as valuable in and of itself as a means to empower recipient communities, and is thought to improve development outcomes by promoting local ownership and civic participation, leading to more sustainable projects (Casey 2018; Mansuri and Rao 2004; Wong and Guggenheim 2018). International actors often view CDD as a means of building social capital and cohesion (see e.g. Fearon et al. 2009; Kim et al. 2020; Vajja and White 2008; Van Domelen 2003).

11 A matching grant refers to a grant where the amount of grant provided is related to the amount raised by communities. Block grants, meanwhile, refer to grants of a predetermined amount, known in advance to communities.

12 A similar assumption is made when development aid is made contingent on evidence of local government revenue-

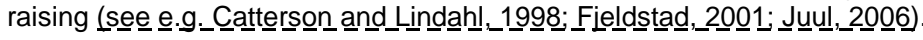

13 For an exploration of this logic in the context of Somaliland, see e.g. Eubank (2012)

14 The idea that community contributions can be efficient in revenue terms is based in part on some evidence that requiring community members to pay can improve targeting of public services, improve the sustainability of public goods, and supplement the budgets of governments or donors, thus increasing the number of projects that may be implemented (Jimenez and Paqueo 1996; Kleemeier 2000). For example, Dongier et al. (20으: 318) note that 'One of the key challenges for scaling up CDD is to stretch public financial resources over a greater number of communities and subprojects. This can be achieved by supplementing public financing with local and private finance sources, promoting market delivery of private goods, and retaining matching grants only for those goods and services that communities and the market will not sufficiently finance. Private and community financing can be mobilized in three ways: through community contributions, credit financing of community contributions, and private commercial investment'.

15 An evaluation of a previous DRC CDD programme found that the effort made by communities to raise contributions toward community projects was 'the greatest catalyst for change and the focal point around which much community collaboration must occur' (DRC 2014). Meanwhile, the theory of change of the DIALOGUE programme includes that, 'People that are willing to provide financial resources for a development project are more likely to demand accountability than people that are not willing to provide financial resources' (DRC and Shaqodoon 2017). 
community contributions have been widely incorporated into CDD programmes, however, little remains known about the impact of co-financing mechanisms, particularly where they involve informal contributions by community members (Tendler 2000).

First, little is known about whether collective action and community contributions can be incentivised. While there is an extensive literature on the impacts of CDD, ${ }^{16}$ there is uncertainty as to whether CDD programmes are effective at incentivising collective action. While CDD programmes are often designed with the goal of building social capital, some evidence suggests that such programmes build on, rather than incentivise, collective action (Isham and Kähkönen 2002; Vajja and White 2008). Specifically, there is mixed evidence of the effect of CDD grants on informal contributions, ${ }^{17}$ while there is limited evidence of the impacts of matching grants, rather than block grants, ${ }^{18}$ and, to the best of our knowledge, no evidence that tracks actual informal contributions, as opposed to contributions estimated through behavioural games (e.g. Fearon_et_al. 2009). At the same time, there is limited evidence about the effects of incentivising contributions that are not strictly voluntary, as in the case of informal revenue generation. ${ }^{19}$

Second, though it is often assumed that matching grant programmes requiring community contributions will lead to more positive public goods outcomes than external aid alone, there is little evidence of this outcome in practice. ${ }^{20}$ By contrast, abundant research points to the risk of elite capture of CDD programmes and community contributions, with local collective action shaped by pre-existing power and social relations (Carrick-Hagenbarth 2016;

Ensminger 2017; Hedlund et al. 2013; Humphreys et al. 2012; Kumar and Corbridge 2002; McCarthy et al. 2016; Mosse 2005; Vajja and White 2008; Van Domelen 2003; White 1999). There is good reason to think that such distortions may be exacerbated by requirements for community financing, with local elites using coercive tactics to raise revenue that may be subsequently used to largely benefit elites, without broader input (e.g. Fjeldstad 2001). As described by White et al. (2018: 17) in a synthesis of evidence of the impact of CDD programmes, 'The requirement for community contributions may engage a large proportion of the community, but their role is restricted to making cash, in-kind or labour contributions, and does not include decision-making' (see also Vajja and White 2008; White 2002). ${ }^{21}$ At the same time, evidence suggests that requirements for local financing within CDD programmes

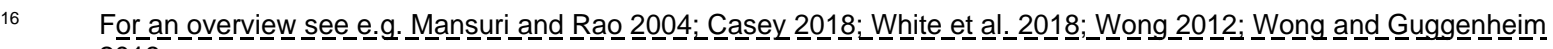
2010․

17 For example, in Sierra Leone, a CDD programme involving a block grant failed to 'catalyze greater collective action or voluntary contributions to public goods in a sustainable fashion' (Casey_et al._2011: 32), though Nguyen and Rieger (2017) show that a CDD programme in Morocco involving block grants can stimulate the willingness to contribute to public good. While not specific to CDD programmes, there is also a growing body of work exploring the effects of foreign aid on individuals' willingness to contribute to public goods, though the evidence is likewise mixed (see $\underline{e}$.g.. Milner_et al .

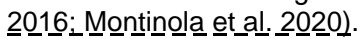

18 An exception to this is a partner study to our research in Gedo region, which finds that a tiered matching grant

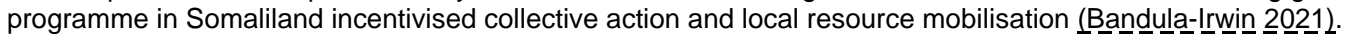

19 There is considerable research on the effects of matching charitable contributions in high-income countries (see e.g. Baker et al. 2009; Eckel and Grossman 2003; Karlan and List 2021; Meier 2007; Rondeau and List 2008), with some limited exploration of the relationship between individual grants matched to voluntary contributions in low-income countries (e.g. Walker 2011). In contrast, there is limited understanding of the impact of matching grants in incentivising informal contributions in contexts where they are enforced through social mechanisms, as is common in many lowincome contexts (e.g. Olken and_Singhal_2011; Paler_et al. 20117; van den B Boogaard et_al._2019), including in southcentral Somalia (see van den Boogaard and Santoro 2021).

20 An exception to this is Brett (2003) who, in a review of studies on CDD, finds that financial contributions by beneficiaries at the implementation stage of projects positively influenced overall project success and sustainability.

Reviewing the research of Vajja and White (2008) in Malawi and Zambia, White et al. (2018: 17) illustratively describe that 'People participated in making bricks, not decisions'. White (2002) further notes that even where community contributions are widespread, some groups, like women and children, may be excluded entirely from decisions about project spending or project management. Similarly, in the context of a matching grant programme to incentivise local government revenue-raising in Tanzania, Fjeldstad (201: $\underline{302})$ notes that donors' presence 'may induce increased tax effort', but that this comes 'at the expense of accountability and democratic consolidation'. Meanwhile, Juul (20으요 $8 \underline{3} 6$ ) notes that donors' assumption that co-financing 'should motivate the population to contribute to their own development obviously does not hold true' in contexts where accountability channels are limited. 
can shape project selection in a way that is not necessarily aligned with citizen preferences. ${ }^{22}$ Further, there is little understanding of the causal mechanisms linking community contributions and public goods outcomes. As noted, it is often assumed that contributing to local projects will make citizens more invested in positive outcomes, though there are growing reasons to be sceptical about the ways in which links between tax and accountability play out in low-income contexts (e.g. Bak 2019; Gadenne 2017; Martin 2016; van den Boogaard et al. 2020), while these links are underexplored in the context of informal taxation. Overall, there is little understanding of the ways in which external grants may transform or distort the accountability relationships between local leaders and taxpayers, if at all.

Third, where community contributions are required, it is unclear whether they serve to crowd out other forms of informal and formal revenue generation. With regard to informal taxes, it is intuitive to think that households may have a budget for informal community contributions. If this is the case, aid delivery modalities requiring informal contributions may simply shift revenue away from other forms of informal revenue generation. To the best of our knowledge, the potential crowding-out effects on other forms of informal revenue generation have not been explored - though these outcomes have significant implications, given the importance of informal tax institutions to the financing of local public goods and informal social welfare institutions in many contexts. Do requirements for community contributions shift revenue away from particular types of public goods in favour of those prioritised by CDD programmes? When considering the impact on formal taxes, meanwhile, there are two possibilities: on the one hand, formal and informal taxes and taxing institutions may be seen as substitutes, with taxpayers viewing informal tax as negating their duty to pay formal taxes. This may be because they believe they have already contributed their fair share to public goods provision, or because they have greater trust in the accountability of informal taxing institutions relative to an ineffectual or corrupt government. ${ }^{23}$ On the other hand, informal taxes may serve as an alternative to a largely absent formal state without representing a rejection of that state, or may serve to 'fund different types of public goods' that the government is not able or eager to fund (Olken and Singhal 2011:25), implying that informal tax payment may have no effect on formal taxes. ${ }^{24}$

Finally - and related to questions about whether informal taxes limit formal tax capacity where development partners work directly with communities to finance public goods outside the state, there remain important questions about the impact on state legitimacy. Indeed, there is limited understanding of the ways in which informal taxes affect perceptions of the state, its capacity and its governing authority. Again, two possibilities emerge, reflecting the ways that co-financing modalities may support either a virtuous or adverse cycle of governance (Blair and Winters 2020; Sacks 2012; Schmelzle and Stollenwerk 2018). On the one hand, the necessity of self-financing public goods may lead citizens to question the legitimacy of the state and reduce their willingness to engage with it - in turn, making it more difficult for the state to raise revenue and provide public goods in the future (see Levi 1988). ${ }^{25}$ This view is in line with some perspectives, particularly from policy actors, about the risks of supporting service provision outside the state, ${ }^{26}$ and may be particularly likely in

\footnotetext{
$22 \quad$ Rawlings et al. (2004) show that local financing requirements can force communities to select projects for which it will it be easier to generate in-kind or labour contributions rather than projects that would require cash, or to select projects that are less expensive to build.

23 As proposed by Olken and Singhal (2011: 25), 'If local governments are corrupt, residents may prefer to make payments toward public projects in a form that cannot be expropriated'.

24 In other words, informal taxes may be an outcome of weak state taxing capacity, rather than a factor limiting state tax capacity. These possibilities may coexist and may reinforce each other.

25 From this perspective informal institutions and political orders are seen as 'rivals to the state and serve as active impediments to the expansion of state authority' (Menkhaus 2014b: 148).

26 For example, the OECD (2011: 83) cautions that service provision through non-state actors 'can undermine strengthening of government systems', with reliance on non-state actors a potential risk to statebuilding activities. Other observers have pointed to the risk of non-state service provision for state autonomy and power (see e.g. Matthews 1997; Obiyan 2005), based on concerns that citizens would start to rely on non-state actors to provide basic services
} 
contexts where state and non-state service provision are clear substitutes. ${ }^{27}$ On the other hand, if co-financing through informal taxation and service delivery outside the state improves public goods outcomes, taxpayer perceptions of government performance may likewise improve, increasing their willingness to cooperate with the state and accept its authority. Thus, co-financing outside the state may counterintuitively support a virtuous cycle of governance, helping weak states to emerge out of 'low-tax, low-capacity' traps. Recent research shows that informal taxation can strengthen, rather than undermine state institutions (van den Boogaard 2020b), while our previous research in Gedo region shows that informal taxes are positively correlated with the legitimacy of the local state and willingness to accepts its authority (van den Boogaard and Santoro 2021). This is in line with a more nuanced view of the relationship between formal and informal institutions (see e.g. Helmke and Levitsky 2004), ${ }^{28}$ as well as with a growing body of evidence that local collective action and non-state service provision can complement or supplement the state (see e.g. Cammett and MacLean 2014; Sacks 2012), and improve citizen perceptions of the state (e.g. Dietrich et al. 2018; Dietrich and Winters 2015). More broadly, this view is in line with research showing the ways in which state and traditional leaders or local elites may be complementary (e.g. Balán et al. 2020; Baldwin 2015, 2019).

Building on these four knowledge gaps we ask:

1. Can matching grants be used to incentivise informal contributions to public goods provision?

2. Can co-financing through informal taxation improve public goods outcomes? If so, through what mechanisms?

3. Do requirements for informal tax contributions within CDD programmes crowd out other forms of formal and informal revenue generation?

4. Does co-financing of public goods provision through informal taxation undermine the legitimacy of the state?

We shed light on these questions in the context of south-central Somalia, where formal state institutions are weak, informal taxing institutions are relatively prevalent and well-established, and there is little evidence of the impact of CDD and matching grant programmes, despite their widespread use by international development partners.

\section{Research design}

We explore the effects of a community-level intervention incentivising informal revenue generation through matching grants in three districts of Gedo region in Jubbaland state in

rather than demanding services from their own governments (Edwards and Hulme 1996; Holzner 2010: 243; Moss et al. 2006; OECD 2008b: 7) and empirical evidence that governments redirect spending to other activities when they are financed through alternative means (Torpey-Saboe 2015). This belief in the substitution of non-state and state service provision is so commonplace among some policy actors that there have been cases of governments asking foreign actors to stop providing public goods because they felt that their legitimacy was undermined by the non-state actors visible role in providing those goods (Ciorciari and Krasner 2018).

27 For example, Bodea and Le Bas (2016: 215) show that '[w] here individuals have access to community-provided goods, which may substitute for effective state services provision, they are less likely to adopt pro-compliance norms' towards the state.Similarly, Ali et al. (2014) find that frequent protection payments to non-state actors reduces the likelihood of having a tax-compliant attitude. Meanwhile, Acemoglu et al. (2020) find that greater trust in public goods provided by the state has a negative impact on citizens' beliefs about non-state actors, and their willingness to engage in non-state public goods.

28 In line with this view, research shows the ways in which informal institutions can cooperate or coexist with formal ones (e.g. Hart 2005; Meagher 1990, 2005; Roitman 1990, 2005), with the potential to sustain, reinforce, or remake state authority (e.g. Cleaver et al. 2013; Lund 2006; Roitman 2005; Titeca 2012; Titeca and De Herdt 2011; Titeca and Flynn 2014). 
south-central Somalia.29 Matching grants were given through the DIALOGUE (Develop Informed and Accountable Local Governance through User Empowerment) programme of the Danish Refugee Council (DRC). DIALOGUE was undertaken in partnership with Shaqodoon, a Somali NGO, and built on the DRC's previous CDD programmes in the region (see e.g. Armstrong 2014; Bryld and Kamau 2013; DRC and Justice Studio 2015; Dias 2011).

To be eligible to participate in the DIALOGUE programme, communities in Gedo region had to first identify a public works project to be jointly funded by communities and the DRC, and then to have community leaders submit a community development project proposal to the DRC. ${ }^{30}$ Community contributions within this study are in line with the most commonly-cited definition of informal tax, capturing contributions to the collective construction of community works projects (Olken and Singhal 2011: 5; see also Walker 2017). Proposals had to pass two criteria set by the DRC: first, the community - made up of a single settlement or a group of settlements that chose to work together for the purposes of the CDD programme - had to be sufficiently accessible for DRC field staff to visit, with some communities excluded because of security concerns; and, second, the public works or community development project had to, as determined by DRC field staff, benefit and be accepted by the community at large. ${ }^{31}$ Of the 62 communities that the DRC determined to be eligible, 31 communities were randomly selected through a public lottery at district level to receive the treatment intervention. Among these communities, we randomly selected 121 sub-community settlements for data collection, with the distribution weighted according to district population. Additionally, the DRC purposively selected seven larger-scale district-level projects for participation upon meeting the baseline eligibility requirements. Of these, only three were included in the study (Dooloow, Luuq and Beled Xaawo) on account of security constraints preventing travel to the other districts.

The treatment involved two components. First, treatment communities received a grant that matched or surpassed revenue raised by communities through informal taxation for a specific community development project, proportional to the amount raised and to the level of interclan collaboration. ${ }^{32}$ The matching grants were financed by the DRC but 'co-managed' with the state government, with funds channelled to community leaders through the Jubbaland State Ministry of Interior. All public communications about the project included the logo of the Jubbaland State Ministry of Interior rather than the DRC (Appendix A). Projects funded at the community level ranged from a total of US $\$ 2,630$ to US $\$ 26,800$ (an average of US $\$ 11,104$ ), with communities contributing a total of US $\$ 112,966$, matched by the DRC with US $\$ 197,935$ - with more in matching grants given the graduated rate of matching grants (Appendix $B$ ). ${ }^{33}$ Meanwhile, the seven larger district-level projects ranged from US $\$ 50,001$ to US\$106,480 (an average of US\$64, 6579), with US $\$ 90,531$ raised informally, matched with US\$362,065.

29 The three districts are Luuq, Beled Xaawo and Dooloow.

30 Community leaders refers to clan elders, leaders of village councils and/or leaders of village development committees.

$31 \quad$ We define settlement in line with the UNFPA's (2014: 118), as 'A group of dwellings comprising different households in a delineated area with clear boundaries'.

32 Community fundraising took place over a 4-month period between June and November 2018, after which matching grants were distributed. The matching contributions were US $\$ 1$ for each dollar raised by a settlement for a small project at the settlement level; US $\$ 2$ for each dollar raised by several settlements for a multi-settlement project; US $\$ 3$ for each dollar raised by different local clans for an inter-clan project that benefitted many communities; and US\$4 for each dollar raised by district authorities for a district-level project. This incentive scheme was intended to foster inter-settlement and inter-clan collaboration. Of the communities that received a grant, $37 \%$ included multiple settlements and $23 \%$ included multiple clans.

33 While the focus of informal revenue-raising was local communities, a small number of individuals in the diaspora contributed to local projects. Members of the diaspora contributed in only 3 treatment communities, though these contributions were relatively substantial (US $\$ 10,000$ for a district-level project and US\$2,000 each for 2 community-level projects). In these cases, diaspora communities raised funds and sent money to a representative in the community, who subsequently contributed the funds to the community bank, with transfers tracked by the Sokaab platform described below. 
A secondary arm of the treatment involved a set of measures aimed to increase oversight over the communities' management of the funds raised through informal taxation and matching grants. In treatment communities, the DRC and Shaqodooon oversaw the establishment of Community Project Implementation Units, which were charged with collecting contributions, managing project implementation, and setting up bank accounts in which treatment communities received the matching grants and community contributions (through in-person or mobile banking services). Matching grants and community contributions were tracked through a publicly accessible online crowdfunding platform and app called Sokaab, which includes an online summary of the revenue contributed by communities (disaggregated by transaction, though anonymised), and expenditure information for the projects (e.g. payments made to construction companies). ${ }^{34}$ After the public lottery, Shaqodoon ran community training meetings in treatment communities on crowdfunding and how to send money to community bank accounts through mobile money. Control communities, meanwhile, did not receive this treatment package, and we are confident that treatment and control communities are comparable across other key indicators (see Appendix C).

Beyond the validity of the comparison, there at least three reasons why treatment and control communities differ from other communities in the region. First, as our study only includes communities that opted into the DIALOGUE programme and submitted proposals for community development projects, it is plausible that participating communities may have a stronger ability to mobilise informal revenue than communities that did not opt in. While our previous experience studying informal taxation and revenue generation in south-central Somalia gives us confidence that the mobilisation of informal taxes is common in the region, the degree and ease of informal revenue generation, as well as perceptions of and willingness to work with the state, may differ based on clan composition, security and extent of social cohesion - all of which vary considerably across south-central Somalia. Second, in order to be eligible for consideration in the DRC programme, settlements had to be safe enough to allow DRC field staff to visit, and thus may not be comparable to less safe ones. ${ }^{35}$ Third, though the population of internally displaced persons (IDPs) in Gedo region is relatively high (estimated in 2014 to be 15 per cent, relative to 9 per cent across the country) (UNFPA 2014), our sample excludes IDP camps. More generally, Gedo region may represent a relatively unique context, potentially limiting the external validity of our findings. As compared with other regions in south-central Somalia, the relative security and homogeneity of communities in Gedo region may limit the replicability of our findings in less secure or homogeneous areas. ${ }^{36}$ At the same time, Gedo region has a uniquely strained relationship with the Jubbaland state administration, with potential implications for individuals'

$34 \quad$ The crowdfunding platform can be viewed at www.sokaab.com. To view an example of one of the projects funded through the DIALOGUE programme, see https://www.sokaab.com/home/view_project?id=28.

35 Even after Jubbaland was incorporated into the Federal Government of Somalia in 2013, al-Shabaab has continued to exercise control in large parts of the rural areas of the state and in most of the rural areas and roads between districts in Gedo region, as well as territory in the south-east of the district (Hagmann 2016; Hiraal Institute 2020; UN Habitat 2018: 5-6). Due to budget and security constraints, we could not survey communities that did not participate in the selection process at all, were not aware of the programme, and did not propose a community development project as part of the programme. While our findings may thus be limited to safer regions, insecurity is a relatively fluid concept in the region, illustrated by the relative unpredictability of the location and frequency of conflict events across districts in the region (Appendix E).

36 The Marehan clan dominates in the region (Menkhaus 2006; UN Habitat,2018). Though this domination is at the expense of the Rahanweyn and other minority groups, the region represents a considerable degree of social homogeneity that may facilitate informal tax mobilisation. Indeed, multiple studies find that greater homogeneity within a community leads to greater social capital and cohesion, in turn either making individuals more likely to contribute to public goods (Akramov and Asante 2008; Fehr and Gächter 2000; Miguel and Gugerty 2005), or making management of public goods provision more efficient (Sun et al. 2010). Meanwhile, despite the continued presence of al-Shabaab, Gedo is perceived to be safer than other regions in Jubbaland state on account of political and economic power being centralised in the hands of an important clan, the Marehan (Menkhaus 2006: 84), having a more homogenous population, and having a significant Ethiopian military presence (UN Habitat 2018: 22). 
willingness to engage with the programme. ${ }^{37}$ We reflect further on the limits to external validity in Section 6.

\section{Data}

Our primary data comes from two original panel surveys with households and community leaders in treatment and control communities in March 2018 and February 2019 (Appendix A). ${ }^{38}$ First, household surveys were conducted with 1,073 randomly selected households at baseline, of which 880 were successfully reached at endline, ${ }^{39}$ capturing formal and informal tax incidence, usage of public goods, perceptions of state and non-state actors and taxation, and civic and political participation. Second, we collected community-level data through surveys with 117 community leaders at baseline across treatment and control communities, of which 107 leaders were reached at endline. These surveys capture community-level data on public services, self-help activities, political and civic decision-making, community groups and civic participation, the nature of formal and informal taxation, security, and information about community development projects.

There are at least three potential limitations to this survey data. First, while it was relatively easy to track village leaders one year later at endline, challenges arose when following up with individuals. Of the 880 surveyed at endline, only about half (391) could be unambiguously linked to baseline. The remaining half could not be traced back to baseline due to identification challenges in the field and a glitch in the survey form. We deal with this issue more specifically in the next section. Second, individuals may underreport the extent of informal tax payments where such payments are illegal. We do not believe this is a concern in Somalia, where many of the forms of informal revenue generation explored are normalised and highly institutionalised. ${ }^{40}$ Third, there is a risk that reported informal contributions are overestimated if survey respondents believe that demonstrating effective mobilisation of community resources would influence the likelihood of communities receiving future financial support from the DRC. ${ }^{41}$ We test for this type of bias and find evidence that community leaders in control communities may be inclined to frame their answers in a way that appeals to NGOs in order to receive matching grants (or other aid modalities) in the future, though we

37 The tension between Gedo region and the Jubbaland state administration is rooted in broader tensions within the federation, including a perceived lack of representation of clan groups (Musau 2013). The leaders of Jubbaland state and the FGS fundamentally disagree over how Somalia's political system should allocate power, with more recent disputes triggered by the federal government's refusal to recognise the Jubbaland elections of 2019 (ICG 2013, 2020: 1 CIT. In this broader conflict, Gedo region is seen to support the FGS, with this support rooted in President Mohamed Abdullahi Mohamed 'Farmajo's ties to Gedo's dominant Marehan clan, as well as the fact that the Jubbaland state has concentrated his security forces and political capital in Lower Juba, far from Gedo region (ICG, 2020: 4; Mwangi 2016). In recent years, after data collection for this study, the federal government has asserted control over some districts in Gedo region, including Luuq, Doolow and Beled Hawo (ICG, 2020, pp. 4M C.

Questionnaires were designed based on an exploratory qualitative study of informal taxation led by one of the authors in Jubbaland and Hirshabelle states, and can be found in the supplementary online appendix.

39 This reflects an attrition rate of $18 \%$. Attrition is not correlated with treatment assignment and was largely the result of security constraints, which meant that 3 communities in Luuq district could not be visited at endline (Appendix C).

$40 \quad$ This is in line with Gallien (2021: 2), who notes that 'the normalization of illegal activities directly influences the risks involved in information sharing' (Meagher et al. 2014; van den Boogaard 2020b: 54-59). Indeed, despite being extralegal, they are not associated with illegality or immorality. This is not surprising given the nature of political order in Somalia, where informal activities are not necessarily 'wrong' any more than formal activities are necessarily 'right' indeed, there is significant evidence that taxpayers are more likely to perceive formal taxes negatively than informal ones (van den Boogaard and Santoro 2021).

There may nevertheless be particular risks (both of underreporting and for the security of research participants) when asking about informal taxation by non-stated armed actors and terrorist groups. To protect respondents, we do not ask directly about informal taxation by non-state armed groups, focusing only on community-based taxation for public goods provision.

41 While the matching grant programme was not affected by survey responses, respondents may have believed that the $\mathrm{DRC}$ would expand the matching grant programme in the region if it was effective in mobilising informal contributions. 
find no such bias among other individuals. ${ }^{42}$ We thus interpret the amount of informal tax contributions reported by community leaders to potentially be overestimated, and rely more heavily on the amounts of contributions reported by individuals themselves.

We further mitigate the risk that informal tax contributions or individual satisfaction with project outcomes are overestimated by relying on two additional sources of directly observable data to complement the survey data. First, enumerators collected directly observable data within targeted communities, capturing the quantity and quality of public services; indicators of local accountability, transparency and decision-making processes; and, at endline, the quality of the community development project that was undertaken throughout the research period. Second, we track community contributions and expenditure on development projects through the Sokaab platform, which tracked community contributions, matching grants and project expenditure. Sokaab data includes details on project implementation and outcomes, expected and actual project expenditure, and total and disaggregated contributions to the project. ${ }^{43}$

\section{Main results}

Building on the knowledge gaps identified in Section 2, we explore the effects of the matching grant programme on three sets of outcomes: informal contributions, project outcomes, and perceptions of state and non-state governance actors. The identification strategy is straightforward, as it relies on the fact that the study is a randomised controlled trial. We regress our outcomes on treatment dummies and additional controls, and estimate results through a linear probability model, according to the following OLS specification: 44

$$
Y_{i}=\alpha i+\beta_{i} \text { Dialogue }_{i}+X_{i} \Gamma+\theta_{i} Y_{0}+\epsilon_{i}
$$

Where the outcome $Y_{i}$ is the ex-post outcome of respondent $i$, as measured at endline. The variable Dialogue $_{i}$ indicates whether respondent $i$ is in a village assigned to DIALOGUE. Therefore, $\beta_{i}$ stands for the causal estimate of impact of the DIALOGUE programme. The set

$42 \quad$ We check for this type of desirability bias by randomising receipt of a survey question that would indicate if respondents were giving answers based on their understanding of what the DRC would want to hear. Respondents were randomly allocated to two groups that were asked two versions of a statement. The unbiased question is: 'Do you agree or disagree that community representatives, such as individuals in a development project committee, should be assigned through community-based elections?'. The biased question included an introductory statement that was meant to test the presence of a social desirability bias in favour of NGOs. The question is: 'Many NGOs in the region believe that elections are always the best way to choose community representatives, such as individuals in a development project committee. Do you agree or disagree with this view?'. In control communities, $85 \%$ of leaders strongly or somewhat agree with the biased statement, relative to $72 \%$ in treatment communities, indicating that community leaders may shift their responses in a way that they believe would be more desirable from an NGO perspective. We find no evidence that household respondents intentionally responded with answers that they perceived to be more desirable for an NGO. Indeed, we find roughly the same balance of agreement with the biased question. If a bias existed, we would have seen an increase in the 'strongly/just agree' answers to the question. We would also have noticed more support from respondents in treatment villages to the question. Instead, respondents' answers were distributed in a similar way across treatment and control villages. The $p$-value of a chi-square test is $35 \%$, showing no significant differences between DIALOGUE and control villages.

43 In addition to this financial data, we relied on data made available by Shaqodoon and the DRC that provided more details about large contributions, including whether contributions were international remittances, contributed by an individual or by a group through one representative donor.

$44 \quad$ For binary outcomes, the linear probability model (LPM) provides easier interpretations for the marginal effects on the probability of outcomes, compared to probit and logit. While the assumption of homoscedascity does not hold in an LPM, calculating robust standard errors does control for that (Angrist and Pischke 2009). Moreover, LPM does not restrict predicted values within the $0-1$ interval - but the share of such values is not high, ranging from $0 \%$ to $3 \%$ of the sample. 
of control variables $X_{i}$ includes respondent level background information. ${ }^{45}$ We run regressions both with and without controls. We also include the baseline outcome variable $Y_{i 0}$ as a pre-treatment control measured at baseline, in an ANCOVA estimation. In this fashion, we reduce the variance of the error term and thus results gain in statistical power (McKenzie 2012). ${ }^{46}$ Baseline outcomes are available for 391 respondents, while baseline values are imputed for those respondents with missing values. ${ }^{47}$ In addition, we add villagelevel fixed effects, in order to capture any time-invariant feature of the village that may be correlated with the outcome, as well as an indicator variable for district capitals (Dooloow, Luuq, Beled Xaawo) since they participated in larger-scale district-level projects (see section $3)$. The error term $\epsilon_{i}$ is clustered at the taxpayer level and robust to heteroscedasticity. Finally, we consider differential attrition concerns. Attrition rate was not extremely high (18\%) but relatively dependent on location. Due to security constraints, three communities in Dooloow could not be visited. This implied that respondents in this district are underrepresented at endline, while those in Beled Xaawo are over-represented. We therefore run all regressions by using sampling weights so as to over- and under-represent Dooloow and Beled Xaawo respondents, respectively. As a last attempt to address attrition, the background variables $X_{i}$ specified above also include some unbalanced features, which are then controlled for in the analysis.

\subsection{Effects on informal contributions to public goods}

We first explore the effects of the matching grant programme on informal contributions to new community development projects undertaken over the period of study. As reported in household surveys, we find that treatment communities are more likely than control communities to have undertaken a new development project in the previous year, and were able to raise more money in informal taxes in support of that community development project. ${ }^{48}$ As described in Table 1 (col. 2), we find an increase of 14 percentage points (p.p.) in the likelihood of having implemented a new project since baseline that can be attributed to the DIALOGUE programme. Apart from being statistically significant, this result is also substantial when compared to the control group mean of 37 per cent, translating into a 38 per cent increase in the likelihood of having a new project in treated communities. Likewise, as described in Table 1 (col. 4), the value of extra contributions raised in treated communities represents more than 10 per cent of what was raised in control ones - 62 p.p. over a control average of 6.60 .

45 Controls include gender, education level, clan, household size, occupation, district in which the respondent lives, whether the respondent lives in an urban or rural area, and baseline usage of mobile money.

46 In the few cases in which the outcome variable is not available at baseline, we omit the lagged-outcome variable.

$47 \quad$ Missing values are imputed to the baseline mean of those respondents with non-missing values. Also, an indicator variable is created to indicate those respondents for which the imputation took place.

$48 \quad$ These positive effects are confirmed by the responses of community leaders. Survey data from community leaders show that treated communities were more likely to start a new project (96\%) than control communities (88\%). Though treatment communities are more likely to start a new project, it is still striking that the vast majority of control communities undertook a new development project without external financing. We attribute this to the fact that control communities had already developed a project proposal, so may have been more prepared to mobilise revenue for a new project - as noted above, informal revenue generation (IRG) for public goods provision is more generally common in the region. 
Table 1 DIALOGUE impact on new community development projects in last year ${ }^{49}$

\begin{tabular}{|l|c|c|c|c|}
\hline & Any new project & Any new project & $\begin{array}{c}\text { (3) } \\
\text { Log total } \\
\text { contributions to new } \\
\text { projects (US\$) }\end{array}$ & $\begin{array}{c}\text { (2) } \\
\text { Log total } \\
\text { contributions to new } \\
\text { projects (US\$) }\end{array}$ \\
\hline Dialogue & $0.13^{* *}$ & $0.68^{* *}$ & $0.62^{* *}$ \\
\hline & $(0.06)$ & $0.14^{* *}$ & $(0.28)$ & $(0.28)$ \\
\hline Controls & No & $(0.06)$ & No & Yes \\
\hline & & Yes & & Yes \\
\hline Village FE & Yes & & Yes & 6.60 \\
\hline Control Y endline & 0.37 & Yes & 6.60 & 0.501 \\
\hline R-sq. & 0.387 & 0.37 & 0.491 & 1019 \\
\hline Observations & 880 & 0.390 & 1019 & \\
\hline
\end{tabular}

Standard errors in parentheses ${ }^{*} p<0.10,{ }^{* *} p<0.05,{ }^{* * *} p<0.01$

These results are consistent with responses from community leaders. In line with the findings from the household survey, community leaders report that 37 per cent and 25 per cent of households contributed to the new projects in treatment and control communities, respectively. This indicates that the DIALOGUE programme increased contributions at the extensive margin. This is in line with the regression results reported in Appendix B Table B2, which show that the DIALOGUE programme significantly improved the extensive margin of contributions, both at the level of a new project being implemented (col. 1-2) and in terms of more households contributing (col 3-4). In terms of the contribution amounts by communities and households, or the intensive margins, as reported by community leaders, results indicate that total contributions are significantly increased by the matching grant programme (Appendix B Table B2, col. 4 and 5), while the average contributions increased, but not significantly. When we compare these results to the more objective data from the Sokaab contribution tracking platform, we find that leaders overestimate these numbers, though we have no reason to believe that overestimations are more skewed in either treatment or control communities. ${ }^{50}$ Overall, the impact evidence from community leaders is statistically significant, despite the small sample size, and confirms the positive impact in Table 1 using household survey data.

We further explore whether incentives to raise informal community taxes made it more difficult to collect formal taxes or informal taxes and contributions outside of the DIALOGUE programme - that is, whether the matching grants had a crowding-out effect on either the state's ability to levy formal taxes or on other informal forms of revenue generation upon which communities rely for local governance, conflict resolution, social protection and service provision (van den Boogaard and Santoro 2021). We observe no crowding-out effect of the DIALOGUE programme on other forms of revenue-raising; instead, we observe an increase in the number of informal taxes collected in treatment communities, with positive impacts on informal taxes paid to religious leaders, clan leaders and to support public goods (Table 2). Positive spillover effects are particularly meaningful for religious contributions, which almost double in treated communities - with a 17 p.p. increase over a control group mean of 0.21 (col. 4). Contributions to clan elders also significantly increase in number, by about half of the control group mean (col. 6). Other informal contributions for public goods provision outside of the DIALOGUE programme also increase, though this increase is weakly significant (col. 8). An anomaly in this pattern arises, however, with respect to informal contributions to village leaders, which do not change as a result of the matching grant programme (col. 2). The

$49 \quad$ For columns 1 and 2, the survey question is: 'Is there any new (since last year) development projects/community improvements in the village that you used at least once?'. For columns 3 and 4, the survey question is: 'Please indicate how much US\$S do you think were raised in total for the project'.

50 In treatment communities, we cross-reference self-reported data with the contributions data from the Sokaab platform, finding that community leaders overestimate the amount of household and total contributions. Community leaders in treatment communities estimate overall contributions at an average of US $\$ 6,945$, contrasted by an average of US $\$ 5,310$ reported on the Sokaab platform. Likewise, community leaders reported that average household contributions were US $\$ 167$, higher than the average of 80 contributions of US $\$ 47$ per project reported on the Sokaab platform. 
peculiarity of the impacts of the DIALOGUE programme on village leaders is a pattern in our findings that is explored in greater detail below. Meanwhile, impacts on formal taxes are null and insignificant, with a very low control group mean (13\%) (Table 2). ${ }^{51}$

\section{Table 2 DIALOGUE impact on IRG (sub-categories)}

\begin{tabular}{|c|c|c|c|c|c|c|c|c|}
\hline & (1) & (2) & (3) & (4) & (5) & (6) & (7) & (8) \\
\hline & $\begin{array}{l}\text { Village } \\
\text { leader }\end{array}$ & $\begin{array}{l}\text { Village } \\
\text { leader }\end{array}$ & Religious & Religious & Clan & Clan & $\begin{array}{l}\text { Pub. } \\
\text { goods }\end{array}$ & $\begin{array}{l}\text { Pub. } \\
\text { goods }\end{array}$ \\
\hline Dialogue & -0.01 & -0.00 & $0.17^{\star \star \star}$ & $0.17^{\star \star \star}$ & $0.44^{\star * \star}$ & $0.44^{* * *}$ & $0.18^{*}$ & $0.16^{*}$ \\
\hline & $(0.05)$ & $(0.05)$ & $(0.05)$ & $(0.05)$ & $(0.14)$ & $(0.14)$ & $(0.11)$ & $(0.11)$ \\
\hline $\begin{array}{l}\text { Baseline } \\
\text { outcome }\end{array}$ & No & Yes & No & Yes & No & Yes & No & Yes \\
\hline Controls & No & Yes & No & Yes & No & Yes & No & Yes \\
\hline Village FE & Yes & Yes & Yes & Yes & Yes & Yes & Yes & Yes \\
\hline Control $\mathrm{Y}$ endline & 0.17 & 0.17 & 0.21 & 0.21 & 0.97 & 0.97 & 0.55 & 0.55 \\
\hline R-sq. & 0.259 & 0.263 & 0.389 & 0.398 & 0.353 & 0.364 & 0.396 & 0.403 \\
\hline Observations & 880 & 880 & 880 & 880 & 880 & 880 & 880 & 880 \\
\hline
\end{tabular}

Note: Standard errors in parentheses. ${ }^{*} p<0.10,{ }^{* *} p<0.05,{ }^{* * *} p<0.01$. The outcome is the raw total of informal contributions for a particular category. Village leader contributions: labour contributions to village leader, conflict resolution fees. Religious fees: Zakat. Clan-based contributions: Diyya, clan debt relief, Qaaran. Public goods contributions: town cleaning, communal labour, support to teachers and schools, CDPs, social payments, group labour to fix a roof.

\subsection{Effects on project outcomes}

We then explore the effects of the DIALOGUE programme on the nature and quality of project outcomes. First, we explore the types of project undertaken through the matching grant programme, building on research that suggests that requirements for community contributions can shape project selection (Rawlings et al. 2004). We find that treatment communities were more likely to build primary schools and meeting halls when compared to control communities (Appendix F Figure F1) - the choice of which project only partly reflects individual preferences at baseline (Appendix F Figure F2). On the one hand, it is positive to see that primary schools were the primary preference of respondents at baseline, and are correspondingly the most common project implemented across treatment and control communities. On the other hand, there are some discrepancies between individual preferences and implemented projects, with, for example, communal water sources and health posts being undertaken at a lower frequency than would be predicted by reported preferences. Likewise, meeting and social halls are rarely desired by households at baseline, and yet they are implemented much more frequently than expected - and more frequently in treatment communities.

Second, we find positive effects on the quality of project outcomes. Individuals in treatment communities were less likely to be dissatisfied with new public goods relative to individuals in control communities (Table 3). Using a 1-5 dissatisfaction index, where 5 indicates maximum dissatisfaction, we find that the index falls by 45 p.p. in treated communities, or about 10 per cent of the control group mean (col. 2). This finding is in line with the more objective assessment of project quality recorded by enumerators at endline, according to which new projects in treatment communities appear to be of a higher quality than those in control communities (Appendix F, Figure F3). ${ }^{52}$ Perhaps correspondingly, we find that individuals in treatment communities are significantly more likely to expect to receive something in return for informal contributions (Table 3). As shown in column 4, the likelihood of individuals

$51 \quad$ Table omitted for brevity and available from the authors upon request.

52 As described in Appendix F Table F1, the DIALOGUE programme's impact on whether the project was actually completed at endline is not significant (albeit of a positive coefficient). This could relate to the short time span (1 year after baseline) after which the endline survey was conducted. 
perceiving that they get something in return for informal contributions increases by 19 p.p. in treatment communities, which is about a third of the control group mean at endline.

Table 3 Dissatisfaction with new community development projects

\begin{tabular}{|l|c|c|c|c|}
\hline & $\begin{array}{c}\text { (1) } \\
\text { Dissatisfaction with } \\
\text { new community } \\
\text { development } \\
\text { projects (max=5) }\end{array}$ & $\begin{array}{c}\text { Dissatisfaction with } \\
\text { new community } \\
\text { development } \\
\text { projects (max=5) }\end{array}$ & $\begin{array}{c}\text { (3) } \\
\text { Perceptions of } \\
\text { getting something in } \\
\text { return for informal } \\
\text { contributions }\end{array}$ & $\begin{array}{c}\text { Perceptions of } \\
\text { getting something in } \\
\text { return for informal } \\
\text { contributions }\end{array}$ \\
\hline Dialogue & $-0.43^{* *+*}$ & $-0.45^{* *+}$ & $0.20^{* *}$ & $0.19^{* *}$ \\
\hline & $(0.12)$ & $(0.12)$ & $(0.09)$ & $(0.10)$ \\
\hline Baseline outcome & - & & No & Yes \\
\hline Controls & No & - & No & Yes \\
\hline Village FE & & Yes & Yes & Yes \\
\hline Control Yend-line & Yes & Yes & 0.66 & 0.66 \\
\hline Control Y baseline & 4.16 & 4.16 & 0.22 & 0.22 \\
\hline R-sq & - & - & 0.451 & 0.471 \\
\hline Observations & 0.372 & 0.375 & 570 & 570 \\
\hline
\end{tabular}

Standard errors in parentheses ${ }^{*} p<0.10,{ }^{* *} p<0.05,{ }^{* * *} p<0.01$

We consider two non-mutually exclusive mechanisms through which these positive public goods outcomes may emerge, both relating to channels of accountability. First, the matching grant programme may increase citizens' capacity or perceptions of their right to demand answers of leaders - what we call, borrowing a term from Schedler (1999), a bottom-up 'answerability' mechanism. For instance, it may be the case that the presence of an external partner led individuals to believe that their demands would be more likely to be listened to, that individuals had a greater incentive to monitor projects because of the higher value of projects in treatment communities as a result of the matching grants, or that the role of an external actor implies higher risks for communities in the case of aid mismanagement, with the potential to threaten future donor relationships. To test this answerability hypothesis, we explore the impact of the DIALOGUE programme on four indicators of community participation and demand-making by citizens. As described in Table 4, we find that the DIALOGUE programme had consistent and significant positive effects on the likelihood of individuals attending meetings (col. 2), playing a role in monitoring community projects (col. 4), asking leaders about public revenue (col. 6), and raising issues with other community members (col. 8). Coefficients are all precisely estimated and represent an increase ranging from a fifth (for monitoring) to a quarter (asking about revenue) of the control group mean.

Table 4 DIALOGUE impact on respondents' 'answerability' actions

\begin{tabular}{|c|c|c|c|c|c|c|c|c|}
\hline & (1) & (2) & (3) & (4) & (5) & (6) & (7) & (8) \\
\hline & $\begin{array}{l}\text { Attend } \\
\text { meeting }\end{array}$ & $\begin{array}{c}\text { Attend } \\
\text { meeting }\end{array}$ & $\begin{array}{l}\text { Monitor } \\
\text { community } \\
\text { project }\end{array}$ & $\begin{array}{l}\text { Monitor } \\
\text { community } \\
\text { project }\end{array}$ & $\begin{array}{l}\text { Ask abt } \\
\text { revenue }\end{array}$ & $\begin{array}{l}\text { Ask abt } \\
\text { revenue }\end{array}$ & $\begin{array}{l}\text { Raise issue } \\
\text { wt other } \\
\text { villagers }\end{array}$ & $\begin{array}{l}\text { Raise issue } \\
\text { wt other } \\
\text { villagers }\end{array}$ \\
\hline Dialogue & $0.13^{\star \star \star}$ & $0.14^{\star \star \star}$ & $0.11^{\text {t* }}$ & $0.11^{* *}$ & $0.18^{\star \star \star}$ & $0.18^{\star \star \star}$ & $0.16^{* *}$ & $0.16^{* *}$ \\
\hline & $(0.05)$ & $(0.05)$ & $(0.05)$ & $(0.05)$ & $(0.05)$ & $(0.05)$ & $(0.05)$ & $(0.05)$ \\
\hline & & & & & & & & \\
\hline outcome & No & Yes & No & Yes & No & Yes & No & Yes \\
\hline Controls & No & Yes & No & Yes & No & Yes & No & Yes \\
\hline & & & & & & & & \\
\hline Village FE & Yes & Yes & Yes & Yes & Yes & Yes & Yes & Yes \\
\hline $\begin{array}{l}\text { Control Y } \\
\text { endline }\end{array}$ & 0.84 & 0.84 & 0.83 & 0.83 & 0.80 & 0.80 & 0.83 & 0.83 \\
\hline $\begin{array}{l}\text { Control Y } \\
\text { baseline }\end{array}$ & 0.26 & 0.26 & 0.09 & 0.09 & 0.16 & 0.16 & 0.16 & 0.16 \\
\hline R-sq. & 0.406 & 0.415 & 0.432 & 0.441 & 0.417 & 0.426 & 0.426 & 0.443 \\
\hline Obs. & 880 & 880 & 880 & 880 & 880 & 880 & 880 & 880 \\
\hline
\end{tabular}

Standard errors in parentheses. ${ }^{*} p<0.10,{ }^{* *} p<0.05,{ }^{* * *} p<0.01$ 
Second, we consider a top-down transparency mechanism, based on longstanding ideas that transparency generates accountability, based on the conventional wisdom that 'sunshine is said to be the best disinfectant, electric light the best policeman' (Louis Brandeis cited in Fox 2007: 664). ${ }^{53}$ From this view, external constraints that make information more transparent force leaders to better manage project outcomes, increasing their responsiveness to taxpayers. This is plausible in the context of the DIALOGUE programme given the role of NGOs in introducing transparency requirements, which may have created external pressure on leaders to be more transparent and to better manage resources. The programme required contributions to be tracked through an online transparency platform (Sokaab) that could, at least in theory, be monitored by community members, NGO staff and government officials. Overall, however, we find mixed evidence of more transparent and inclusive decision-making in treatment communities as a result of the DIALOGUE programme. As described in Table 5, respondents in treatment communities were more likely to report that a distinct committee had been set up to manage the project, the likelihood of which increases by a substantial 60 per cent of the control group mean (col. 2); that they had been consulted in person about the project, a 50 per cent increase in the likelihood of that happening in treated communities compared to control communities (col. 4); and, with weak significance, that the project had been decided through a community meeting, representing an increase of a third of the control group average (col. 6). ${ }^{54}$ At the same time, however, individuals in treatment communities reported less frequent information sharing and meetings about the project (Table 6). Both outcomes show a statistically significant reduction when compared to the control group.

Table 5 DIALOGUE impact on inclusive decision making ${ }^{55}$

\begin{tabular}{|c|c|c|c|c|c|c|}
\hline & (1) & (2) & (3) & (4) & (5) & (6) \\
\hline & $\begin{array}{c}\text { Project } \\
\text { committee } \\
\text { formed }\end{array}$ & $\begin{array}{c}\text { Project } \\
\text { committee } \\
\text { formed }\end{array}$ & $\begin{array}{c}\text { Resp. } \\
\text { Consulted }\end{array}$ & $\begin{array}{c}\text { Resp. } \\
\text { Consulted }\end{array}$ & $\begin{array}{l}\text { Community } \\
\text { decision }\end{array}$ & $\begin{array}{c}\text { Community } \\
\text { decision }\end{array}$ \\
\hline Dialogue & $0.22^{* * \star}$ & $0.20^{\star \star \star}$ & $0.18^{\star \star \star}$ & $0.17^{\star \star \star}$ & 0.09 & $0.10^{*}$ \\
\hline & $(0.06)$ & $(0.06)$ & $(0.05)$ & $(0.05)$ & $(0.05)$ & $(0.05)$ \\
\hline Controls & No & Yes & No & Yes & No & Yes \\
\hline Village FE & Yes & Yes & Yes & Yes & Yes & Yes \\
\hline $\begin{array}{l}\text { Control Y } \\
\text { endline }\end{array}$ & 0.33 & 0.33 & 0.38 & 0.38 & 0.35 & 0.35 \\
\hline R-sq. & 0.413 & 0.423 & 0.344 & 0.350 & 0.421 & 0.428 \\
\hline Observations & 957 & 957 & 1030 & 1030 & 1030 & 1030 \\
\hline
\end{tabular}

Standard errors in parentheses ${ }^{*} p<0.10,{ }^{* *} p<0.05,{ }^{* * *} p<0.01$

\footnotetext{
53 A more nuanced theory of transparency and accountability based on empirical evidence recognises that transparency is 'necessary but far from sufficient to produce accountability' (Fox 2007: 665).

54 This last finding is in line with the fact that project choices in treatment communities were aligned, at least partially, with household baseline preferences (see Appendix F Figures F1, F2).

55 In col. 1-2, the survey question is: 'Was a distinct development planning committee set up specifically to help manage the project?'. In col. 3-4: 'Were you consulted in person about the choice of the project?'. In col. 5-6: 'How was the project chosen?', and the outcome is a $0-1$ variable for whether the project has been chosen with a community meeting where a consensus has been reached.
} 
Table 6 DIALOGUE impact on frequency of information sharing about new project ${ }^{56}$

\begin{tabular}{|l|c|c|c|c|}
\hline & $\mathbf{( 1 )}$ & $\mathbf{( 2 )}$ & $\mathbf{( 3 )}$ & $\mathbf{( 4 )}$ \\
\hline Dialogue & $\begin{array}{c}\text { Sharing info } \\
\text { frequency (max=7) }\end{array}$ & $\begin{array}{c}\text { Sharing info } \\
\text { frequency (max=7) }\end{array}$ & $\begin{array}{c}\text { Meeting frequency } \\
(\mathbf{m a x}=7)\end{array}$ & $\begin{array}{c}\text { Meeting frequency } \\
\text { (max=7) }\end{array}$ \\
\hline & $-0.45^{* *}$ & $-0.45^{* *}$ & $-0.73^{*+*}$ & $(0.23)$ \\
\hline & $(0.22)$ & $(0.22)$ & $(0.23)$ & Yes \\
\hline Controls & & & & \\
\hline & No & Yes & No & Yes \\
\hline Village FE & & & Yes & 4.25 \\
\hline Control Y endline & 4.30 & Yes & 4.25 & 0.382 \\
\hline R-sq. & 0.392 & 4.30 & 0.373 & 1030 \\
\hline Observations & 1030 & 0.397 & 1030 & \\
\hline
\end{tabular}

Standard errors in parentheses. ${ }^{*} p<0.10,{ }^{* *} p<0.05,{ }^{* * *} p<0.01$

\subsection{Effects on perceptions of governance actors}

Finally, we consider the effects of the matching grant programme on perceptions of state and non-state governance actors, exploring whether incentivising informal tax contributions through matching grants and delivering public goods outside state institutions supports or undermines citizen perceptions of the state and its legitimacy. Legitimacy reflects the willingness to accept the state's authority (Baynes 2001; Levi et al. 2009; Levi and Sacks 2009; Risse and Stollenwerk 2018), allowing governments to rely on citizens' voluntary - or quasi-voluntary - compliance with state policies, with the effect of decreasing the costs of policy implementation and improving the efficiency of the provision of public goods. In this way, state legitimacy is deeply related to a state's capacity 'to get things done' (Centeno et al. 2017: 13; see also Englebert 2002; Fukuyama 1995, 2013). The measurement of legitimacy, however, is challenging for at least three key reasons. Individuals may have different conceptual understandings of legitimacy (Beetham 1991: 13); behavioural indicators of compliance with the state may not necessarily correlate to beliefs of legitimacy, as individuals may comply with taxation out of fear or other rational reasons (Schaar 1984), while enforcement may be unrelated to citizen perceptions of the state; and observers may be unable to differentiate individuals' support for the regime in power and acceptance of state institutions more broadly (Guerrero 2011).

Tax morale - attitudes among taxpayers towards paying taxes - avoids some of the issues in measuring state legitimacy, as it better reflects taxpayer perceptions of the right of the state to govern rather than behavioural measures, and is removed from ideas of the regime in power. As our goal is to capture broad acceptance of government authority rather than perceptions of government performance or taxpayer behaviour, we use a measure of tax morale that captures an individual's expressed attitude towards the right of an actor to levy taxes or fees, ${ }^{57}$ regardless of that actor's behaviour (Prichard forthcoming). ${ }^{58}$ Thus using an

56 In col. 1-2, the survey question is: 'How often was information about the project shared with the community?'. In col. 3-4: 'How often was a community meeting held in the village to discuss the project and give updates to the villagers?', and the outcome is a 1-7 index variable increasing with the frequency of information sharing and village meetings.

$57 \quad$ While tax may be conceptualised differently in different contexts and languages, the piloting and translation exercises undertaken during fieldwork give us confidence that the measures of tax morale to different governance actors fundamentally relates to citizens' willingness to assent to that actor's authority. This is particularly the case as the survey question captured both an actor's authority to levy taxes (canshuur) and informal contributions (yabooh dhaqaale la siiyo). Accordingly, tax morale is not limited to formal tax payments, and captures a wider range of possible payments This is particularly important in the context of south-central Somalia, where formal tax collection is minimal in practice. Indeed, even though a small proportion of citizens paid any taxes to the local state at baseline (van den Boogaard and Santoro 2021), we are confident that our measure of tax morale captures citizens' willingness to accept the authority of the local state, even in a context where they have little experience of paying taxes to the state. We are thus confident that we capture a reasonable measure of legitimacy that is comparable across governance actors that levy different types of payments. For more on the nature of these different types of payments, see van den Boogaard and Santoro (2021).

58 Within the survey, respondents were asked: 'Do you agree or disagree that [x actor] always has the right to make people pay taxes or make contributions?' Our outcome takes value 1 if the respondent agrees or strongly agrees with the statement, and zero otherwise. 
unconditional measure of tax morale, capturing the acceptance of an actor's governing authority, we disentangle legitimacy from performance or trust. ${ }^{59}$ As we capture it, tax morale reflects a 'citizen's assent to tax both reflects and defines state-society relations', with willingness to accept tax authority as 'an ongoing and constant gauge of the legitimacy of the state in the eyes of citizens' (D'Arcy 2011: 1). Where willingness to pay taxes to a given actor is high, we can infer that individuals accept the right of that actor to collect taxes and govern. ${ }^{60}$

Using tax morale as a proxy for a given actor's legitimacy, we find that the DIALOGUE programme had significant positive effects on the legitimacy of local state and non-state governance actors (Table 7). Perhaps most surprisingly, given that the local government played no direct role in the matching grant programme, perceptions of the legitimacy of the district government improved in treatment relative to control communities (col. 2), with belief in the district government's right to make people pay taxes (tax morale) increased by about 20 p.p. - or a third of the control group average. While we find similar positive increases in perceptions of the authority of clan elders (an increase of $28 \%$ of the control group mean, col. 6) and, an even stronger effect for religious leaders (an increase of $38 \%$ of the control group mean, col. 8), we see no such improvement for the (non-state) village council (col. 4). The latter finding is directly related to the poor spillover effects on contributions to village leaders as described in Table 2 above.

Table 7 Impact on actor's legitimacy

\begin{tabular}{|c|c|c|c|c|c|c|c|c|}
\hline & (1) & (2) & (3) & (4) & (5) & (6) & (7) & (8) \\
\hline & District & District & Village & Village & Clan & Clan & Religious & Religious \\
\hline Dialogue & $0.22^{* * *}$ & $0.22^{* *+*}$ & 0.03 & 0.03 & $0.19^{\text {t*t* }}$ & $0.19^{* *+*}$ & $0.25^{* * t}$ & $0.25^{* * *}$ \\
\hline & $(0.07)$ & $(0.07)$ & $(0.05)$ & $(0.06)$ & $(0.06)$ & $(0.06)$ & $(0.06)$ & $(0.06)$ \\
\hline $\begin{array}{l}\text { Baseline } \\
\text { outcome }\end{array}$ & No & Yes & No & Yes & No & Yes & No & Yes \\
\hline Controls & No & Yes & No & Yes & No & Yes & No & Yes \\
\hline Village FE & Yes & Yes & Yes & Yes. & Yes & Yes & Yes & Yes \\
\hline $\begin{array}{l}\text { Control Y } \\
\text { end-line }\end{array}$ & 0.67 & 0.67 & 0.77 & 0.77 & 0.68 & 0.68 & 0.66 & 0.66 \\
\hline $\begin{array}{l}\text { Control Y } \\
\text { baseline }\end{array}$ & 0.45 & 0.45 & 0.65 & 0.65 & 0.66 & 0.66 & 0.61 & 0.61 \\
\hline R-sq. & 0.324 & 0.330 & 0.259 & 0.267 & 0.314 & 0.318 & 0.360 & 0.366 \\
\hline Obs. & 866 & 866 & 869 & 869 & 867 & 867 & 847 & 847 \\
\hline
\end{tabular}

Standard errors in parentheses. ${ }^{*} p<0.10,{ }^{* *} p<0.05,{ }^{* * *} p<0.01$

We explore four mechanisms through which these outcomes may be explained. First, for an engagement-based mechanism, we consider whether positive outcomes for state legitimacy and perceptions of the state are related to greater engagement with state officials. This is based on the idea that relationships formed at the point of service delivery affect citizens' perceptions of the state (Bodea and LeBas 2016; Fisk and Cherney 2017; Karim 2020; see also Robinson 2008; Tsai 2011). ${ }^{61}$ While the DIALOGUE intervention appears to have led to an increase in the level of interaction with district officials and perceptions of the inclusivity of the district government in decision-making processes, the estimates are not significant at any

$59 \quad$ This in line with Dreier and Lake (2019), who show that 'Individuals from diverse demographic backgrounds imbue state institutions with the right to perform their governance and law-enforcement duties, even after experiencing institutional incompetence or injustice'. They show that individuals' trust in state institutions breaks down following negative firsthand experience, but that their faith in the institutions themselves does not change. (Fukuyauma 2013: 3533; Lieberman_2002; Wang and A Angang 2001).

61 For example, Karim (2020: 536) argues that 'relationships between state agents and citizens drive positive attitude formation, because these relationships provide information and facilitate social bonds', with relationship building between state agents and citizens being 'an important part of statebuilding'. 
level and therefore are inconclusive (Appendix G Table G1). In contrast, when we consider non-state governance actors, we observe significant increases in perceptions of the inclusivity of religious leaders and clan elders in treatment communities, in line with increases in the belief that these actors always have the right to collect tax (Appendix $G$ Table G2). In line with the lack of impact that we find on village leaders' legitimacy, citizen interactions with and perceptions of the inclusivity of these actors is not positively impacted by the DIALOGUE programme. ${ }^{62}$

Second, we consider a performance-based mechanism, based on a body of literature that emphasises the link between effective delivery of goods and services and perceptions of the state (Braithwaite and Levi 1998; McLoughlin 2015; Sacks and Larizza 2012; Schmelzle and Stollenwerk 2018 and corresponding special issue; Weber 1962; Zartman 1995; Ziblatt 2008). In line with this, and as shown in Appendix $H$, we find a positive relationship between the matching grant programme and perceptions of the transparency, trust and performance of the district government and religious leaders (Appendix $\mathrm{H}$ Tables $\mathrm{H} 1$ and $\mathrm{H} 3$ ). The impact on clan elders is inconclusive (Appendix $\mathrm{H}$ Table H4). Finally, in line with the pattern of perceptions of tax morale, trust in village leaders and perceptions of their transparency are not shaped by the DIALOGUE programme, while perceptions of their performance, relative to the previous year's performance assessment, are actually negatively impacted by the programme (Appendix H Table H2).

Third, we consider a false attribution mechanism, based on the idea that where positive public goods outcomes are delivered, it may be necessary for citizens to attribute outcomes to the state in order for the state to benefit (McLoughlin 2015; Sacks 2012; Schmelzle and Stollenwerk 2018; Stollenwerk 2018). As described by van den Boogaard (2020b: 282) it is possible that informal taxes 'may positively contribute to state legitimacy by visibly improving the quality of public goods if citizens attribute those improvements to the state'. Accordingly, we further explore to whom individuals attributed the matching grant programme, which involved project development, implementation, and informal revenue generation by community leaders (including the village council or village development committee), external funding and monitoring by an NGO, and a role for the state government in distributing the matching grant funds. There is some indication that community leaders viewed the role of the local government as important. As described by a community leader in Beled Xaawo, the matching grant programme was 'the first project of its kind in this area, where the district authority worked closely with the community leadership and representatives in delivering a project as truly collaborating partners' (cited in SSF 2019). As described in

62 Related to this engagement-based mechanism, we further tested for a clientelism mechanism, exploring whether being known personally by a particular governance actor impacted perceptions of that actor's legitimacy. We find no evidence for this clientelism mechanism. 
Figure 1, however, few individuals in treatment communities attributed any role of the programme to the government, instead highlighting the role of the NGO, the village council and the community development council. ${ }^{63}$ This indicates that increased positive perceptions of the state were not a result of the project being mistakenly directly attributed to it.

63 While attribution is often assumed to be ambiguous and unclear (Cruz and Schneider 2017), Fjeldstad (2001) similarly finds that this isn't always the case, with citizens in some contexts clearly distinguishing between government services and donor-provided services. 


\section{Figure 1 Perceptions of project leaders}

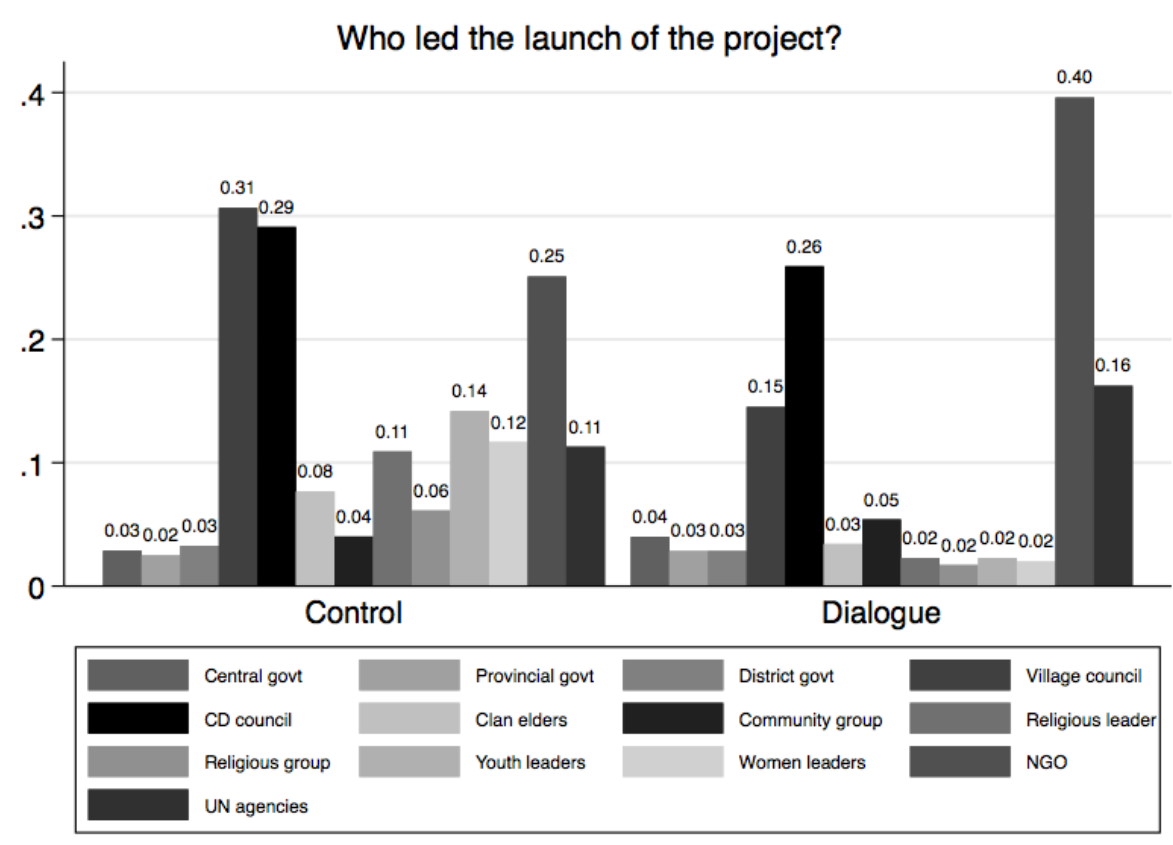

Finally, we test an informal contributions mechanism, considering how informal revenue generation interacts with the DIALOGUE programme to explain the impact on perceptions of legitimacy. Indeed, improvements in an actor's legitimacy may be explained by increased informal contributions, spurred by the DIALOGUE programme (see Table 2 above). Table 8 reports the estimate of a specification including the interaction term between an indicator variable for being in a treated village and an indicator for the respondent contributing more than the median in the sample at endline. If the increase in informal revenue generation, as attributed to the programme, is a mediator for the positive changes in actors' legitimacy, we would expect the interaction term Dialogue* $I R G$ to show a statistically significant coefficient in Table 8. However, that is not the case here, and results are inconclusive. The interaction term is never significant for any actor. The DIALOGUE programme alone (Dialogue variable in Table 8) retains the same positive impact on the legitimacy of district government, clan elders and religious leaders as shown in Table 7, while increased informal revenue generation is shown to not be the mechanism at play. Further, higher informal revenue generation alone (IRG variable in Table 8 ) is positively correlated with religious leaders' legitimacy - a correlation which has already been identified in van den Boogaard and Santoro (2021). We can therefore conclude that increased contributions are not the channel through which the matching grant programme improves actors' legitimacy. Some other mechanisms, which we are unable to explore further with the available data, must be at play. We leave the study of such mechanisms to future research. 
Table 8 DIALOGUE impact on actors' legitimacy - interactions with IRG

\begin{tabular}{|c|c|c|c|c|c|c|c|c|}
\hline & (1) & (2) & (3) & (4) & (5) & (6) & (7) & (8) \\
\hline & District & District & Village & Village & Clan & Clan & Religious & Religious \\
\hline Dialogue & $0.23^{* * *}$ & $0.23^{* * *}$ & -0.00 & -0.00 & $0.16^{* *}$ & $0.16^{* *}$ & $0.23^{* * t}$ & $0.23^{*+*}$ \\
\hline & $(0.07)$ & $(0.07)$ & $(0.06)$ & $(0.06)$ & $(0.07)$ & $(0.07)$ & $(0.07)$ & $(0.07)$ \\
\hline Dialogue* $I R G$ & -0.05 & -0.03 & 0.09 & 0.09 & 0.06 & 0.06 & -0.03 & -0.02 \\
\hline & $(0.08)$ & $(0.08)$ & $(0.08)$ & $(0.08)$ & $(0.08)$ & $(0.08)$ & $(0.07)$ & $(0.07)$ \\
\hline IRG & 0.01 & 0.01 & -0.04 & -0.05 & 0.03 & 0.03 & $0.12^{* *}$ & $0.12^{\text {** }}$ \\
\hline & $(0.05)$ & $(0.05)$ & $(0.06)$ & $(0.06)$ & $(0.06)$ & $(0.06)$ & $(0.06)$ & $(0.06)$ \\
\hline Baseline outcome & No & Yes & No & Yes & No & Yes & No & Yes \\
\hline Controls & No & Yes & No & Yes & No & Yes & No & Yes \\
\hline Village FE & Yes & Yes & Yes & Yes & Yes & Yes & Yes & Yes \\
\hline Control $Y$ endline & 0.67 & 0.67 & 0.77 & 0.77 & 0.68 & 0.68 & 0.66 & 0.66 \\
\hline Control $\mathrm{Y}$ baseline & 0.45 & 0.45 & 0.65 & 0.65 & 0.66 & 0.66 & 0.61 & 0.61 \\
\hline R-sq. & 0.324 & 0.330 & 0.261 & 0.268 & 0.318 & 0.321 & 0.370 & 0.376 \\
\hline Observations & 866 & 866 & 869 & 869 & 867 & 867 & 847 & 847 \\
\hline
\end{tabular}

Standard errors in parentheses ${ }^{*} p<0.10,{ }^{* *} p<0.05,{ }^{* * *} p<0.01$

\section{Discussion: co-financing CDD through informal taxes}

Overall, we find that the DIALOGUE matching grant programme in Gedo region had a positive effect on key outcomes of interest, including with regard to the effectiveness of cofinancing CDD and the externalities that such an aid delivery modality can have on state and non-state governance actors. Our research contributes to the relatively limited evidence base in this area, and contrasts with concerns that co-financed CDD programmes can lead to elite capture or that operating outside formal institutional channels can undermine the state. We reflect in turn on these findings and how they emerged - highlighting in particular the strong foundation of informal taxation and governance in the region and the role of accountability channels spurred by the programme - and contemplate the limits to external validity of our findings.

\subsection{Effectiveness of co-financing CDD}

The effectiveness of a co-financing model of CDD depends on two key questions: did the programme incentivise local contributions, and did it lead to better public goods outcomes? First, we find that the matching grant programme had a positive effect on the capacity of communities to undertake development projects and to raise informal taxes to finance local public goods. Given the relatively high baseline of informal taxation and the institutionalisation of informal taxing institutions in Gedo region, this finding is in itself somewhat surprising. Indeed, while it is often assumed that grants that match contributions or voluntary donations will incentivise individuals to contribute, there is no evidence that these incentives would be as strong in a context where baseline informal revenue generation is already relatively high, and, importantly, where informal contributions are not strictly voluntary, but enforced through social and informal political mechanisms. As described above, control communities still raised considerable informal revenue to undertake development projects. Even in such a context, however, the matching grant programme served to significantly increase the likelihood of communities undertaking a new community development project, and increased the amount of informal taxes to support the project. Our evidence thus supports the notion that CDD programmes can effectively build on existing 
social capital, while also providing evidence that they can incentivise further collective action even in cases with relatively high baseline contributions. ${ }^{64}$

There is an open question, however, of the extent to which these would be replicable in less secure or homogeneous areas, with, as noted in Section 2, the degree and ease of informal revenue generation expected to differ based on clan family, degree of security and extent of social cohesion. More broadly, the context of south-central Somalia may be unique in terms of local revenue-raising capacity, given its long history of reliance on informal institutions and revenue, with informal taxing institutions prevalent, institutionalised and relatively well-trusted by citizens (van den Boogaard and Santoro 2021). Where a threshold of social capital does not exist, the ability of matching grants to incentivise contributions or build local collective action is uncertain, in part because the social conditions required for informal revenue generation and community mobilisation are likely to be shaped by long-run and deeply embedded structural factors, such as conflict, colonialism and state capacity (e.g. Bowles and Gintis 2004; Nunn 2008). Nevertheless, despite the reality that Somalia may be a relatively extreme case in terms of having strong enabling conditions for informal revenue generation, widespread evidence suggests that it is not an outlier, as 'informal taxation is geographically isolated to a particular region of the world' (Olken and Singhal 2011: 6). ${ }^{65}$ Meanwhile, there is no established theory of conflict, social cohesion and informal revenue generation, further suggesting that informal revenue-raising capacity is not limited geographically. ${ }^{66}$

Second, while the existing literature on CDD highlights the risk of elite capture of programmes - and while there is good reason to think that these risks may be particularly acute where local financing is required (see Fjeldstad 2001) - the matching grant programme had an overall positive impact on the quality of project outcomes. ${ }^{67}$ Overall, we find significant evidence that the matching grant programme improved individual satisfaction with project outcomes and perceptions of fiscal reciprocity. This is supported by enumerators' observations that the quality of new projects in treatment communities was higher than those undertaken in control communities. Our findings indicate that the positive project outcomes associated with the matching grant programme may be the result of a combination of greater community participation and transparency requirements embedded within the programme. As a result of the programme, individuals appear to be more likely to perceive and exercise their right to demand accountability, contributing to greater answerability of local leaders. ${ }^{68}$ At the same time, transparency requirements seem to have led leaders to engage in more inclusive decision-making, though less frequent information-sharing about the project throughout the year. While we are uncertain of the reasons for this discrepancy in leaders'

64 Supporting this, an evaluation of the programme commissioned by the implementing NGO found that 'one of the greatest impacts noted from interviews with community members is the sense of self-reliance' (Smart Vision 2019: 30). As one youth leader in Luuq described, 'This project has shown us that when community come together [sic], then we can do a lot to take care of our welfare. We trust that the school we have built ... is just the first step of the ladder to what we can do through such projects' (cited in Smart Vision 2019: 30).

65 Indeed, informal taxation and revenue generation is documented in diverse contexts (Olken and Singhal 2011; van den Boogaard 2020b; Paler et al. 2017).

On one hand, state weakness resulting from conflict may force communities to mobilise and self-finance essential goods and services. On the other, conflict-affected regions may be more divided and less cohesive, with local leaders less able to levy informal taxes.

67 At the same time, while we observe imperfect matching of project selection to citizen preferences across treatment and control communities, preference alignment is higher in treatment communities. Some of this misalignment in treatment communities can likely be explained by the role that the NGO played in shaping some decisions about project outcomes. For example, despite citizens' preference for health care facilities, communities were dissuaded from constructing health posts, given external concerns about the sustainability of their management. To some degree, this may indicate that the CDD programme limited certain types of public goods being produced, in line with Rawlings et al. (2004).

$68 \quad$ This is in contrast to the idea that external aid can distort the accountability relationships between taxpayers and local leaders (Fjeldstad 2001; Moore 1998, 2004), but is in line with a more nuanced understanding of the relationship between aid, tax and accountability, which highlights the importance of how aid is structured and delivered for determining its impact on local revenue-raising and accountability (Prichard et al. 2012). 
actions, we speculate that though information is being shared less frequently in treatment communities, decision-making seems to be more inclusive when it does happen.

Nevertheless, our findings give us reason to be sceptical of the impact of top-down transparency measures, particularly when relying on digital media. For one, while the majority of individuals reported believing that clan elders and religious leaders involve them in decision-making, the majority of clan leaders also reported that they have total authority to make decisions on behalf of the community without having to get community input (Appendix F Figure F4). At the same time there is also a possibility that, because leaders knew project information was going to be publicly tracked via the Sokaab platform, they had less incentive to provide information to citizens - regardless of how easily citizens were able to access that information in practice. Indeed, our evidence suggests that the tracking platform was not accessible to all community members. ${ }^{69}$ Future research may further explore the impact of transparency requirements, including the relative value of more frequent versus more inclusive meetings, and the incentive for leaders to share more or less information as a result of the project design.

Though our outcomes suggest that the matching grant programme encouraged individuals in treatment communities to take ownership over local public goods, we are nevertheless unable to test one of the central assumptions underpinning the requirements for community contributions within CDD programmes - that individuals are more likely to hold their leaders to account and to take ownership over the project when they contribute directly to projects. As explained in Appendix I, in treatment communities individuals who contributed to the DIALOGUE programme were more likely than those who did not to engage in actions that indicate they are demanding accountability of local leaders. While the finding is only correlational, it does suggestion some support for a link between informal tax payment and accountability. However, given that both treatment and control communities undertook new development projects through informal contributions, we are unable to assess the impact of the contributions themselves, as opposed to the co-financing package given in treatment communities. Future research could usefully explore the extent to which these outcomes could be achieved with a transparent grant without community contributions. ${ }^{70}$ Moreover, despite the positive outcomes, given the timeframe of data collection we are unable to explore the longer-term impact of the programme on the sustainability of public goods outcomes. This is important given that a key assumption embedded within the requirement for local financing is the greater sustainability of the public goods over time - with the idea that where they have contributed to their construction, citizens will be more likely to continue to invest in the maintenance of the public goods in the future - as well as evidence

The platform may have been inaccessible for two key reasons. First, internet usage in the case districts is low. As many as $79 \%$ of the 1,300 interviewees reported never using the internet as a source of information at baseline. Likewise, in $57 \%$ of the villages the cell service is, if not unreliable, of average quality. Second, as noted above, taxpayer knowledge about the projects is likewise low, indicating that knowledge available on the Sokaab platform was not available to all community members, including those that contributed to the public works projects. In treatment villages, only $60 \%$ of respondents were aware that the new community projects were related to the DIALOGUE programme.

An open question remains about the extent to which the role of an external actor alone may have led to these positive outcomes, rather than the co-financing combination. Evidence from a subsequent study of matching grants, informal revenue generation and trust in Somalia found that NGO oversight was a key driver of trust in the overall project and resultant positive perceptions of citizens (Bandula-Irwin 2021), rather than the requirement for local financing. Despite the theory of tax and accountability predicting that leaders will be more accountable where they are reliant on local financing, it is possible that external grants alone may have led to greater demands for answerability if citizens believed that future funding may be dependent on the NGO perceiving positive outcomes. While, as noted in Section 4, we find no evidence of individual responses being shaped by a desire to be seen positively by an NGO, we do find evidence that community leaders may be more conscious of ensuring that outcomes are portrayed as being in line with NGO preferences. It is thus possible that they were influenced by a desire to be seen as accountable to external rather than local actors. Future research may usefully explore how different modalities of aid delivery influence the accountability relations between citizens and local leaders. This is particularly the case given the long history and importance of NGOs in the region, which implies that it may be necessary to consider further the extent to which results were influenced by the NGOs' prior interactions with communities, and perceptions of their ability to ensure external monitoring of funds that enabled more positive developments (Usmani et al. 2018; see also Peters et al. 2018; Vivalt 2020). Accordingly, the replicability of our findings to regions with less prior history or trust in NGOs is uncertain. 
elsewhere that external interventions and grants, particularly in relation to CDD programmes, do not necessarily have long-term transformative effects (e.g. Casey et al. 2011).

\subsection{Spillover effects for state and non-state actors}

In addition to the direct project outcomes, our findings point to important spillover effects of the matching grant programme on local state and non-state governance actors. First, we find no crowding-out effects on other forms of informal revenue-raising; by contrast, we actually find positive spillover effects of the matching grant programme on other types of informal revenue generation. This implies that requirements for local financing did not simply shift revenue away from the financing of other public goods and systems of social welfare provision. This is in line with research on informal taxation in other contexts that shows that formal and informal taxes are not necessarily substitutes, and may thus not result in crowding-out effects (van den Boogaard 2020b: 259-292). Meanwhile our previous research in the context gives us good reason to speculate that individuals do not perceive different types of informal taxes as substitutes (van den Boogaard and Santoro 2021), but rather as often distinct types of payments serving different purposes that are not necessarily in competition. Meanwhile, we find no effects of the programme on formal tax collection, though this is unsurprising in the context given limited baseline formal tax collection, and the underlying lack of capacity of the local government to collect and enforce taxation.

Second, we find that the matching grant programme led citizens to hold more positive perceptions of the legitimacy of clan leaders, religious leaders and the district government. This finding is particularly surprising in the case of the district government, given that it did not have a role in funding the public goods undertaken, and, all things being equal, may not be expected to get credit for the results. Our evidence thus points to important complementarities between formal and informal institutions, in contrast to common assumptions that formal institutions are at odds with informal institutions or de facto modes of governance. ${ }^{71}$ Rather than showing that public goods provided by state and non-state actors being substitutes, and thus in competition with each other (see e.g. Acemoglu et al. 2020), our research contributes to a growing body of evidence pointing to the complementarities between state and non-state actors in governance and service provision (Baldwin 2015, 2019; Baldwin and Holzinger 2019; Cammett and MacLean 2014; Sacks 2012), between formal and informal institutions, and between formal and informal taxation (van den Boogaard 2020b; van den Boogaard and Santoro 2021). More broadly, our findings align with a growing body of research that shows the ways in which customary and state authority can be complementary, with perceptions of traditional authority positively linked to elected government officials (Baldwin 2013, 2015; Chlouba 2020; Henn 2018; Holzinger et al. 2016; Logan 2009; Van der Windt et al. 2018).

This finding is particularly significant as it indicates the potential for the programme to spur a virtuous cycle of governance (Blair and Winters 2020; Schmelzle and Stollenwerk 2018), with increased legitimacy linked to quasi-voluntary tax compliance, linked to greater tax revenue, linked to greater capacity to provide public goods, linked to greater legitimacy. While we do not assess the impact of the programme on quasi-voluntary tax compliance or the longerterm impact on local state tax capacity, our findings nevertheless suggest that co-financed CDD programmes may be able to contribute in some contexts to overcoming the "low-tax, low-capacity' trap faced by many low-income states. Our findings are particularly important in the context of Gedo region, where all levels of the Somali government have limited reach and capacity, because of the overall lack of legitimacy and capacity of local governments (World Bank 2020: 93-97), and the importance of the legitimacy of state actors to the viability of ongoing statebuilding processes. The state sees the importance of this outcome for its capacity to rule. According to an official from the Jubbaland Ministry of Finance, 'The type of

For an illustration of this view in the context of Somalia, see e.g. World Bank $(2 \underline{20} \underline{2} \underline{0}: \underline{8} \underline{6},-1 \underline{0} \underline{3})$. 
participation that the DIALOGUE project pursues has enhanced a sense of ownership in all project activities and has increased trust between government and citizens. In turn, citizens feel that the governance system has changed and that the government is ready to deliver services to the village level' (cited in SSF (2019).

In exploring the causal links between the matching grant programme and legitimacy of the governance actors, we find only partial evidence that legitimacy was strengthened through more frequent interactions with non-state leaders, and no evidence that greater engagement with state officials had any impact on citizen perceptions of legitimacy. This may reflect a key point noted by Dreier and Lake (2019): the impact of engagement may have more profound effects on citizen trust in the state rather than citizen perceptions of the state's legitimacy. ${ }^{72}$ Alternatively, and in line with literature linking effective public goods provision and positive perceptions of the state, we find significant evidence of a positive relationship between the DIALOGUE programme and perceptions of the transparency, trust and performance of the district government, clan elders and religious leaders, indicating that a performance-based mechanism helps to explain observed outcomes. This indicates that where informal revenue generation helps to finance valued public goods, taxpayers may view the state as doing its job and more trustworthy - even if it does not control the revenue. The fact that the performance of village leaders was not similarly affected by the matching grant programme helps to explain why perceptions of their legitimacy did not increase as a result of the programme - future research could usefully further parse the heterogeneous role of local governance actors in order to explain this anomaly.

Meanwhile, though respondents did not directly attribute the programme to the local state, evidence from elsewhere suggests that citizens may give credit to state actors for playing a role in facilitating aid or service delivery, even where the state has no direct role in the outcomes. ${ }^{73}$ In Gedo region, it may be the case that individuals credited the local government for enabling the programme in indirect ways - which van den Boogaard (2020b) suggests may include lobbying for development programmes, allowing NGOs to access physical space, or giving necessary authorisation. As described in other contexts of contested political orders, the delivery of public goods and services by non-state providers can in and of itself be viewed by citizens as something worthy of recognition, with the idea that the state is acting as a broker or intermediary of development rather than a direct service provider (see e.g. McCarthy and Farrelly 2020; van den Boogaard 2020b). This indirect role is plausible given that the Somali Stability Fund (2019), ${ }^{74}$ the funder of the DIALOGUE programme, notes that the programme improved collaboration with the state and district government, which, given the underlying tension between Gedo/ Jubbaland (see Section 2), it sees as a 'welcome by-product of the DIALOGUE project'.

As above, there is some question of the extent to which the complementarities that we observe between different forms of informal taxation, and between co-financing and the legitimacy of local governance actors, will travel to contexts with less well-established or less well-trusted informal tax and governance institutions. Given the history and importance of informal tax and twilight institutions, future research should further explore the relationship between informal taxing institutions, and between informal taxing institutions and the state, in

72 Relying on data from 29 countries in sub-Saharan Africa, they note that 'it is individuals' trust in the institutions of the state (specifically, the agent that represent it) that breaks down in the face of negative first-hand experiences, rather than their faith in the institutions themselves'.

73 Considering the role of NGOs in service provision, e.g. Sacks (2012: 3) finds that non-state provision of services strengthens, rather than undermines, citizens' legitimating beliefs about the state when 'citizens view their government as essential to leveraging and managing these external resources', with citizens crediting the state for development outcomes. Similarly, Winters et al. (2018) suggest that the very presence of external aid can signal government competence to citizens, and Cruz and Schneider (2017) note that attribution of credit for NGO work can be ambiguous to evaluate, as citizens may reasonably infer that government helped to coordinate NGOs' efforts.

74 The Somali Stability Fund is a multi-donor initiative financed by Denmark, the EU, the Netherlands, Sweden, the UK and the United Arab Emirates. It is administered by a private consultancy firm, Adam Smith International. 
diverse contexts. At the same time, we are unable to assess the longer-term transformational impact of the matching grant programme. Future research would be valuable in assessing the time sensitivity of improved citizens' perceptions of governance actors. More generally, we are unable to assess whether citizen perceptions of the legitimacy of the local government extends to higher levels of government, ${ }^{75}$ particularly in Gedo region, given its uniquely strained relationship with the Jubbaland state administration. Beyond Gedo region, it is unclear whether the complementarities may exist beyond the local governance level, where external interventions have been most effective (Menkhaus 2014c: 162-166), given uneven support for the ongoing federalising and statebuilding process more broadly across south-central Somalia (see e.g. Allen and Gundel 2017; Crouch and Chevreau 2016; Mosley 2015). ${ }^{76}$

\section{Implications for development partners and the Somali state}

Despite the limitations to external validity discussed above, our findings have important implications for how international and state actors engage with informal institutions and nonstate actors in revenue-raising and the provision of public goods in Somalia. The dominant view of statebuilding programmes in Somalia has been that informal governance has no significance to statebuilding, thus leading international actors to focus exclusively on formal state institutions and processes. ${ }^{77}$ The donor community has invested heavily in formal institutions, underpinned by 'the assumption that the government can boost its legitimacy by delivering services to the population in areas under its authority, and that, moreover, this should take place within a framework of downward accountability, reinforced as the government funds its services from domestic taxation and revenue generation' (de Waal 2017: 21; see also Federal Republic of Somalia 2013; Hearn and Zimmerman 2014; IMF 2017; UNOSOM 2014; World Bank 2017). Meanwhile, humanitarian and development partners have often treated informal institutions and non-state actors as a stop-gap measure: necessary to delivery essential public goods and services in the face of state failure and weakness, but something that will fade away. As Menkhaus (2006: 102) notes: 'Somalia's informal systems of governance have generally been accorded little to no role in external efforts to revive a conventional state ... The accepted, unspoken wisdom has been that local, informal systems of governance are of little significance, mere variations on a broader theme of anarchy. They are viewed as short-term coping mechanisms to be replaced by formal state authority once the elusive state-building projects succeeds'.

In contrast to these common views, our evidence suggests that, in Gedo region, co-financing development through community-based informal revenue generation may both be a means of supporting public goods provision in a context of weak formal taxation, and reinforcing the authority of the local state. While the focus of the international community has been on formal institutions, formal tax capacity and top-down accountability, we show that state legitimacy, at least at the local level, can also emerge through informal taxation and

\footnotetext{
75 Research elsewhere indicates that informal revenue generation can impact broader measures of state legitimacy, focused at the national level (van den Boogaard 2020 b), though given the tenuous nature of the federation in Somalia, the extent to which similar positive relationships extend to higher levels of government is uncertain.

We expect that outcomes for governance actors will differ depending on the government actor involved and the degree to which community leaders support that actor or the broader statebuilding project at the sub-national or federal level.

77 Statebuilding in Somalia has largely been a top-down and externally-driven process, centrally focused on the Federal Government of Somalia and the Federal Member States (de Waal 2017; Hagmann 2016; Menkhaus 2006, 2014b, 2014a; Stremlau 2016). See Chandler (2007) for a discussion of how the role of international institutions in shaping the goals of statebuilding has limited the viability of alternative models of statebuilding in fragile contexts.
} 
engagement with local non-state leaders. ${ }^{78}$ In practice this implies the need to take into account the role and importance of informal institutions, recognise their potentially complementary relationship to state institutions, and incorporate them within a model of 'mediated' statehood (Menkhaus 2007, 2014). Such a mediated model of statehood understands public authority to be multifaceted, involving interaction between formal and informal actors that 'are (partly) dependent on each other and therefore (partly) shape each other's governance projects' (Stel 2017: 368). ${ }^{79}$ In this context, our evidence suggests that development partners may effectively work with communities and community leaders essentially, to work with the grain of existing social and governance structures - without undermining state actors, and potentially even strengthening the state's legitimacy. ${ }^{80}$ Rather than simply trying to recreate institutions 'in the self-image of the Western liberal state' (Cramer 2006: 257), working with non-state actors to raise revenue and deliver services may represent an effective mode of governance in the context of south-central Somalia. Building on our evidence, this view of modern statehood in Somalia implies that informal institutions are not simply a product of failed governance, and thus something that will lose strength or importance as state institutions strengthen. Rather, informal institutions and non-state actors are deeply intertwined with the mediated state. ${ }^{81}$

Despite these possibilities, international development partners need to consider at least three interrelated risks before partnering with local leaders in hybrid revenue-raising and service provision, or requiring informal contributions as a condition for receiving development aid. First, relying on or requiring community contributions risks reinforcing unaccountable informal institutions and non-democratically elected leaders, effectively 'distorting the normal democratic process that is supposed to legitimize public action' (De Herdt and Olivier de Sardan 2015: 11). As described in Section 2, the risks of elite capture of CDD programmes is considerable, particularly in the context of Somalia where local leaders have considerable power and influence. ${ }^{82}$ In the context of Gedo region this need for caution is considerable,

78 In this context, our findings may imply that greater accountability is possible through local engagement and hybrid cofinancing models, in particular because of the long history of 'the role of external aid in dysfunctional statebuilding' and 'elite extraversion' (Hagmann 2016: 6, 10), which has often undermined the accountability of external aid.

79 This in line with Migdal's (1994: 20-21) notion that the state is but one actor of many social forces that seek to 'mobilize followers and exercise power'. As Menkhaus (2006: 103) notes, a mediated state relies on diverse actors, including local intermediaries and rival sources of authority, 'to execute core functions of government and mediate relations between local communities and the state'.

80 This accords with ideas that in conflict-affected contexts and areas of limited statehood, it may be particularly important to work with informal institutions and local leaders with a 'good-enough governance' or 'functional governance' approach (see e.g. Hickey 2012; Meagher et al. 2014; Menkhaus 2006; Ramalingam et al. 2014). Working with local leaders in the context of Somalia is particularly sensible given that 'real political power' is 'radically decentralized' (Menkhaus 1998: 224), while 'formal state structures have rarely been effective' (Menkhaus 2011: 11). Citizens view non-state actors more positively than the state across a range of measures (van den Boogaard and Santoro 2021), while there is a growing body of evidence of the ways in which local elites may be more effective at mobilising revenue and delivering services than the state in areas of weak formal statehood (see e.g. Acemoglu et al. 2020; Alatas et al. 2019; Balán et al. 2020; Basurto et al. 2020; van den Boogaard 2020b).

81 This is in line with van den Boogaard (2020b: 347), who argues that 'Informality does not simply disappear with modernisation; instead, it is a deeply modern phenomenon, underpinning the state and its authority. States may use informal taxing actors to bolster state authority and expansion, while IRG [informal revenue generation] can support statebuilding processes'. It is also in line with broader critiques of the view that informality is antithetical to modernity and statebuilding, recognising that informality 'has not been eradicated by economic development, statebuilding, globalisation, or the spread of democracy' (Radnitz 2011: 367; see also Farrell 2009; Ganev 2007; Hertog 2010; Tsai 2007). Development partners are increasingly recognising that a transitional means of thinking about informal institutions may not be appropriate. For example, the World Bank (2020: 90) asks "whether such "hybrid" governance should be treated as a transitional measure whereby the relative importance of non-state actors decreases as state capacity is fully developed, or whether it should be adopted as a long-term governance strategy' - though it is not yet clear how this type of long-term perspective of informality and hybridity fits within their programming. Indeed, international actors have 'struggled to understand these arrangements and their place in wider state-building efforts' (Menkhaus 2014c: 154). See Chandler (2007) for a discussion of how the role of international institutions in shaping the goals of statebuilding has limited the viability of alternative models of statebuilding in fragile contexts.

82 For example, Bryld et al. (2013) highlight some of the negative impact of having to rely on gatekeepers in order to access communities or programme beneficiaries, while Hoehne $(2010,2011)$ shows how clan elites and authorities in Sool region in Somaliland are viewed by some in the community as political opportunists. Meanwhile, in Somaliland Renders and Tenderlin (2010) show that informal hybrid arrangements may not be socially legitimate. For broader 
given the uneven nature of clan decision-making, the lack of inclusiveness of local governance, and the considerable influence and capacity of leaders to extract revenue from citizens. ${ }^{83}$ For instance, as noted above, the majority of clan leaders reported that they have total authority to make decisions on behalf of the community, without having to get community input. Meanwhile, while perceptions of clan elders and religious leaders are more positive than perceptions of the district governments, perceptions of these leaders' transparency and performance are still relatively low (van den Boogaard and Santoro 2021). At the same time, while external actors may label community contributions within CDD as voluntary, our research in the region suggests that the majority of individuals do not view informal taxes as voluntary. ${ }^{84}$ In this context, relying on clan leadership has particularly important implications for vulnerable and marginalised populations that are excluded from local institutions of governance, including women and members of minority clan groups (Hill 2010; Hudson et al. 2015; Majid and McDowell 2012). ${ }^{85}$ Accordingly, and recognising the distortive potential of aid in fragile contexts and in Somalia in particular (see Hagmann 2016; Menkhaus 2014a), projects supported should be conscious of local incentives, minorities, and should be relatively small and well-calibrated to avoid potential distortions of local institutions and accountability relations (Menkhaus 2014c). ${ }^{86}$

Second, while relying on informal revenue generation may help to fill gaps left by weak state capacity, it nevertheless has important equity and distributional implications. Existing evidence across diverse contexts shows that informal taxation is often regressive (see e.g. Evans et al. 2020; McCarthy 2016; Olken and Singhal 2011; van den Boogaard et al. 2019; Walker 2017). Our research in south-central Somalia shows that while vulnerable populations are less likely to pay informal taxes and fees, informal payments are regressive at the intensive margin among those that make any payments (van den Boogaard and Santoro 2021). In considering the distributional effects of informal taxation within the DIALOGUE programme, we find that richer households in treatment communities are only slightly more likely than poorer ones to contribute to the DIALOGUE-related project, indicating weak evidence of progressivity at the extensive margin (see Figure 2). At the intensive margin, however, we find stronger evidence of a progressive effect on the first four wealth quintiles, though this fades away with the top quintile. These results should be taken with a note of caution: while we are sufficiently powered to explore the extensive margin with the full sample, the intensive margin analysis becomes noisier, given that a smaller portion of respondents self-report having contributed to DIALOGUE with a non-zero payment. We leave a more in-depth investigation of these equity outcomes to future research.

discussion of concerns about equity and inclusivity within CDD programmes, see Huq (2020); Mansuri and Rao (2004); McCarthy et al. (2016); Saguin (2018).

83 In Somalia, there is considerable variation in how clan leaders are selected. Some are hereditary (common among Darod and Dir clans), others are elected by a council comprised of heads of tribal sections (Hinds 2013; Lewis 1988). Regardless of selection process, many observers describe the ways in which traditional clan authorities have been integrated into formal political structures has distorted traditional legitimacy and accountability processes between elders and communities (see e.g. Hussein 2018; Ssereo 2003; Zoppi 2017)‘.

84 Across all informal tax types, an average of $70 \%$ of taxpayers reported that punishment is likely for non-payment of informal payments - a notably higher percentage than for the formal livestock tax (the only formal tax that more than $10 \%$ of respondents paid), for which only $42 \%$ of taxpayers believed that non-payment was likely to result in punishment (van den Boogaard and Santoro 2021). Meanwhile, in a parallel study of matching grants in Somaliland, evidence suggests that despite frequent communication from the NGO (the DRC) about the voluntary nature of contributions, many citizens believed contributions were mandatory, with indications that people felt some pressure or obligation to contribute to religious leaders and clan elders (Bandula-Irwin 2021). This is in line with theoretical understandings of informal taxation as often being viewed as mandatory by individuals (van den Boogaard 2020b), and with broader evidence pointing to considerable variation in how individuals in communities perceive contributions in practice (see Rawlings et al. 2004).

85 As described by Hill (2010: 3), 'the clan structure affords protection and privilege to majority groups', while 'minorities suffer marginalisation and exclusion from mainstream economic, social and political life'.

86 As Hagmann (2016: 60) argues, 'More effort is required to identify formal and informal institutions ... which have existed before and independently of external funding opportunities and which might become partners for joint statebuilding interventions at local and national levels'. 


\section{Figure 2 Likelihood (left) and incidence (right) of informal contributions to the DIALOGUE programme by $\mathrm{HH}$ wealth quintiles}
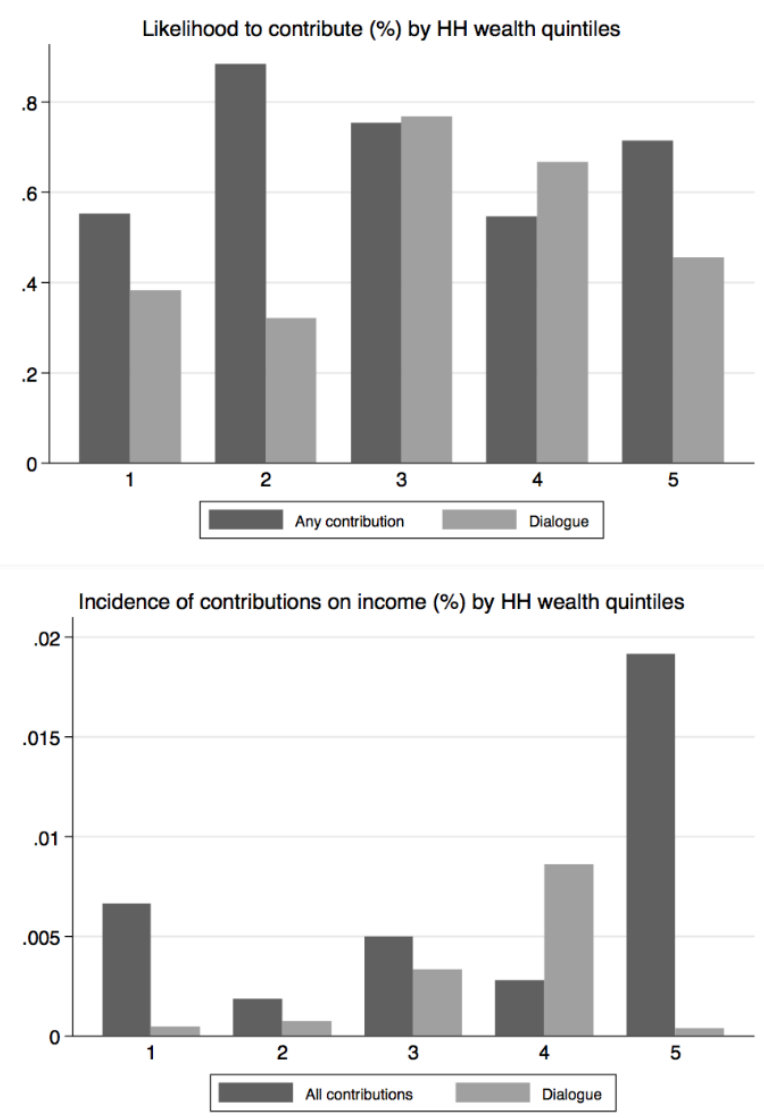

While our evidence thus does not suggest that the matching grants programme in Gedo exacerbated inequity, it is nevertheless true that, in the absence of a centralised redistributive system, the programme reinforces disparate decentralised systems of redistribution that create community-level inequities. ${ }^{87}$ Indeed, the localisation of public goods finance and funding public goods through voluntary contributions means that the quality of public goods - and whether they exist at all - depends on the relative wealth of a particular community, implying uneven sub-national distributional effects (van den Boogaard 2020b, 2020a). In Somalia, where essential services or social welfare are dependent on informal networks, the risk of excluding the most vulnerable is high (see Maxwell and Majid 2016: 114-115). In Gedo region, we find that on average individuals in wealthier communities make more informal payments and contributions than in poorer ones, reinforcing our understanding that 'where there is no centralised redistributive system, communities will have unequal capacity to fill the revenue and service provision gap left by the state' (van den Boogaard and Santoro 2021). Donor requirements for community contributions in CDD programmes often take into consideration levels of poverty overall, ${ }^{88}$ though not necessarily inequity within communities. Where community contributions are required by CDD programmes, 'The inability to pay can limit the participation of poorer communities and poorer groups within communities' (White et al. 2018; see also Chase 2002; Nkonya et al. 2008). This raises some questions, therefore, about the value of matching grants versus

87 Similarly, evaluations of CDD have found that, while it can be effective in building infrastructure, it does not actually transform social relations or have an impact on equity, inclusion or empowerment (3ie 2018; Casey 2018; McCarthy et al. 2016; Mvukiyehe and van der Windt 2020; Saguin 2018; Vajja and White 2008; Wong 2012; Wong and Guggenheim 2018).

88 For example, in the Philippines and Indonesia Wong (2012) finds that mandated community contributions within World Bank CDD programmes were often waived because of extreme poverty, while in other cases contribution requirements were lowered because they were found to be 'too onerous'. 
equalisation payments, which may not have the same effects of consolidating or increasing inequity across regions (see e.g. Shah 2010, 2014).

More fundamentally, though requirements for community contributions are often justified on the basis of a lack of tax payment and contribution to public goods funding, ${ }^{89}$ a growing body of research shows that households and communities have high informal tax burdens and contribute a great deal to public goods provision (Olken and Singhal 2011; Paler et al. 2017; van den Boogaard et al. 2019). In Gedo region, we find that over 70 per cent of respondents report having paid at least one informal tax or fee in the previous year, with informal payments representing on average 9.5 per cent of annual household income (van den Boogaard and Santoro 2021). This raises questions about the fairness of placing the responsibility of poverty reduction upon the poor themselves, while, as Fine (2015) argues, failing to address structural issues of poverty and vulnerability.

Finally, and relatedly, where communities are required to raise informal revenue locally in order to receive support from development partners or the government, there is a risk of institutionalising a non-universal conception of citizenship and rights. In conflict-affected contexts in particular, there are important questions remaining about the distributional impact of both aid and community contributions, and the implications for social cohesion and stability. ${ }^{90}$ With any non-universal distribution of benefits, there is a risk that non-beneficiary groups will be dissatisfied with the outcomes or perceive unfairness in the process or outcome of distribution. In other contexts, intragroup conflict has been documented as a result of the distribution of non-universal benefits (see e.g. Pavanello et al. 2016; Samuels et al. 2013). We find some evidence that these concerns are valid in the context of the DIALOGUE programme. As described in Table 9, we find no significant differences across treatment and control communities in perceptions of how communities were selected to receive matching grants (col. 2). Unsurprisingly, given the high demand for matching grants across all communities, respondents in treatment communities are significantly happier in the selection outcome than those in control communities (col. 4). Critically for concerns about the link between non-universal benefits and social cohesion, we find a marginally significant increase in treatment communities of perceptions that the matching grant programme created resentment and competition between villages that were selected to receive the treatment package and those that were not (col. 6). Meanwhile, although the DIALOGUE programme aimed to increase social cohesion in part by incentivising inter-settlement and inter-clan cooperation (see Section 3), we see no significant effects of the programme on individuals' reported trust in other clans (col. 8).

\footnotetext{
89 As Walker (2011: 17) argues, 'The practice of raising additional funds for local development from community members has a number of advantages ... [t]hese individuals are rarely subject to income tax and therefore shoulder a very small tax burden. Some form of voluntary co-payment seems justified for public projects that offer direct benefits to the local community'.

90 While CDD is often thought to increase social cohesion (e.g. Kim et al. 2020), a growing body of evidence suggests that in both the short and long run CDD delivers on infrastructure, but does not lead to positive or significant changes in social cohesion or other welfare outcomes (e.g. 3ie 2018; Casey 2018; Humphreys et al. 2012; Mansuri and Rao 2004; McCarthy et al. 2016; Mvukiyehe and van der Windt 2020; Vajja and White 2008; White et al. 2018; Wong 2012; Wong and Guggenheim 2018).
} 
Table 9 DIALOGUE impact on cross-community resentment ${ }^{91}$

\begin{tabular}{|c|c|c|c|c|c|c|c|c|}
\hline & (1) & (2) & (3) & (4) & (5) & (6) & (7) & (8) \\
\hline & $\begin{array}{l}\text { Public } \\
\text { lottery }\end{array}$ & $\begin{array}{l}\text { Public } \\
\text { lottery }\end{array}$ & $\begin{array}{l}\text { Happy for } \\
\text { having } \\
\text { been } \\
\text { selected or } \\
\text { not }\end{array}$ & $\begin{array}{l}\text { Happy for } \\
\text { having } \\
\text { been } \\
\text { selected or } \\
\text { not }\end{array}$ & Resentment & Resentment & $\begin{array}{l}\text { Trust in } \\
\text { other } \\
\text { clans }\end{array}$ & $\begin{array}{l}\text { Trust in } \\
\text { other } \\
\text { clans }\end{array}$ \\
\hline Dialogue & -0.04 & -0.04 & $0.19^{* * t+}$ & $0.19^{\star \star \star}$ & $0.10^{*}$ & $0.11^{*}$ & -0.04 & -0.03 \\
\hline & $(0.05)$ & $(0.05)$ & $(0.06)$ & $(0.06)$ & $(0.06)$ & $(0.06)$ & $(0.06)$ & $(0.06)$ \\
\hline Controls & No & Yes & No & Yes & No & Yes & No & Yes \\
\hline Village FE & Yes & Yes & Yes & Yes & Yes & Yes & Yes & Yes \\
\hline $\begin{array}{l}\text { Control Y } \\
\text { endline }\end{array}$ & 0.83 & 0.83 & 0.70 & 0.70 & 0.43 & 0.43 & 0.79 & 0.79 \\
\hline $\begin{array}{l}\text { Control Y } \\
\text { baseline }\end{array}$ & - & - & - & - & - & - & 0.83 & 0.83 \\
\hline R-sq. & 0.358 & 0.361 & 0.382 & 0.389 & 0.394 & 0.397 & 0.258 & 0.271 \\
\hline Observations & 880 & 880 & 880 & 880 & 880 & 880 & 872 & 872 \\
\hline
\end{tabular}

Standard errors in parentheses ${ }^{*} p<0.10,{ }^{* *} p<0.05,{ }^{* * *} p<0.01$. Baseline outcomes are missing since the questions above have been asked at endline only.

Nevertheless, where the state and development partners require communities to make informal contributions in order to receive support or basic services, it is effectively defining who is a worthy or deserving beneficiary (see e.g. Handley 2020: 153-158; McCarthy 2018, 2019; Meagher 2012; Moskowitz 2017; van den Boogaard 2020b). Relying on informal systems of tax collection and public goods delivery thus has significant implications - not only for distributional outcomes, but also for related ideas of the rights and benefits of citizenship. A non-universal conception of citizenship has important implications both for equity outcomes and for social cohesion and stability at a broader scale than we are able to assess through this research. National and sub-national politics in Somalia have long been fraught with tensions over who is included and excluded from development and state- and nation-building processes. As noted in section 3, for example, in Gedo region the Marehan clan dominates local political institutions, at the expense of minority populations, while there are further divisions within the Marehan that can create conflicts over power and resources. ${ }^{92}$ At the same time, broader clan-based tensions in Jubbaland state and south-central Somalia can create tensions over resource distribution. Since the start of the civil war in 1988, resources have been deeply contested by clans, particularly in the Jubba regions (Menkhaus 2012: 4), with tensions emerging because of a lack of perceived fairness in the distribution of resources and service delivery, exclusion of women, and marginalisation of smaller clans (Rift Valley Institute 2017) ${ }^{93}$ In any context, though particularly such a fragile one, a nonuniversal conception of citizenship or distribution of development has the potential to further sow mistrust and inter- and intra-group tensions. ${ }^{94}$ These risks require donor engagement to

91 Survey questions: (i) in col. 1-2, 'How do you think your village has been (not) chosen to participate in this programme?', (ii) in col. 3-4, 'How happy or unhappy are you that you were (not) chosen to participate in this programme?'; (iii) in col. 5-6, 'Do you think the matching grant project created some resentment and competition among villages that were selected to participate and those that weren't?'; (iv) in col. 7-8, 'In general, how much trust or mistrust do you have towards people that do not belong to your clan'.

92 Minority populations include the Raxanweyn, Ogaden and Harti clans and Bantu populations, while there is an intraclan split between original habitants (guri) and new settlers (galti). These divisions are neither universal nor inevitable. Indeed, in Luuq district, clan leaders established a guurti in the early 2000s that included representation of both the Raxanweyn and Marehan clan families (Gundel 2006)

93 The consequence of feeling excluded in this context is significant - e.g. fuelling al-Shabaab's recruitment and support (Menkhaus 2012: 5; Mwangi 2016).

94 Of course, a non-universal allocation of resources tied to clear, public and predictable criteria - whether informal community contributions or the need of the community - may still be less likely to increase tension or negatively affect social cohesion than government-based redistribution, which is widely viewed as being characterised by patronage and clan-based interests (e.g. Ingiriis 2015). This is relevant when thinking whether CDD programmes may eventually be taken over by the state. In the meantime, however, development partners need to consider the implications and risks of incentivising informal taxing institutions as opposed to delivering aid through other more equalising modalities. 
be informed by contextual knowledge, rather than 'template-driven projects' (Menkhaus, 2014c: 154), with an emphasis on accountability, equity and inclusion.

\section{Conclusions}

Our research in Gedo region in south-central Somalia shows that CDD programmes that incorporate grants matched to informal community-level contributions can effectively incentivise contributions for public goods and improve the quality of public goods, suggesting that matching grants can both build on and build social capital and incentivise local collective action. Our findings shed new light on the causal mechanisms linking CDD programmes to more positive public goods outcomes, showing that such a programme in Somalia had an effect through both citizens' greater sense of their rights to demand answers of leaders and external pressure on leaders to be more transparent and inclusive with local revenue-raising and project management. Importantly, this programme did not crowd out other forms of informal revenue generation important to local governance and public goods provision. Instead, we find that the CDD programme increased other forms of informal contributions and strengthened the legitimacy of the local government, which played no direct role in the programme, as well as some local non-state actors. Despite the risks associated with informal taxation, especially with regard to equity and the exclusion of sub-populations, our findings indicate that co-financing of CDD through informal taxation can have a positive impact on social capital, local public goods outcomes, and state and non-state governance actors. These results are striking, contributing to our understanding of the ways in which external intervention can increase social capital and local collective action (Casey et al. 2013; Fearon et al. 2009), the causal mechanisms between community participation and public goods outcomes, and the potential complementarities between formal and informal institutions in a context of weak state institutional capacity. Exploring whether co-financing supports virtuous or adverse cycles of governance - essentially, whether it fuels or helps to overcome low-tax, low-capacity traps - has particularly important implications in a weak and fragile institutional context like Somalia. Indeed, while the international community has invested heavily in supporting the creation of formal state institutions at both the federal and sub-national level, it has, likewise, predominately delivered services outside state channels and relies on local leaders and informal institutions in order to deliver services and aid. ${ }^{95}$

While our research thus has important theoretical and policy implications, it also raises new questions for future research. First, as discussed above, given the potentially unique context of Gedo region, future research may usefully test whether our results hold in an area not dominated by a single clan, that is less stable, or where the co-financing actor had less history of engagement in the region. Likewise, given the relatively unique context of Somalia, with its long history of non-state actors and informal revenue generation being critical to local governance and service provision, future research should explore the extent to which our results persist in less extreme cases. As noted above, informal revenue generation is prevalent across weak state institutional contexts, while there are some indications that informal taxing institutions may lead to greater state legitimacy in other contexts. Our understanding of these relationships and the causal mechanisms nevertheless remains relatively limited.

Second, while we find a positive relationship between the matching grant programme and the legitimacy of the district government, we were limited in asking about support for broader ongoing statebuilding processes in the region. Future research may explore the extent to which different levels of government enjoy positive benefits from the matching grant

95 De Waal (2017) notes that only about $8 \%$ of official development assistance is delivered directly to the FGS Ministry of Finance, which is well below the $15 \%$ target that has been agreed by donors. 
programme, and the extent to which citizen support translates to broader support for ongoing statebuilding processes. As described above, research elsewhere indicates that informal revenue generation can impact broader measures of state legitimacy, focused at the national level. Given the tenuous nature of the federation in Somalia, the extent to which similar positive relationships extend to higher levels of government is uncertain. These questions have important implications for international development partners, who, as noted above, focus support to a much greater extent to the federal government and the federal member states, rather than local government institutions - many of which have not yet been formally established.

Third, future work is required to enable a more nuanced understanding of the results and causal mechanisms at play. For instance, while we observe no 'crowding-out' effects on other informal contributions, and while we speculate that this is indicative of individuals not perceiving different types of informal taxes as substitutes, it remains unclear why the CDD programme actually led to increases in some types of informal taxes. Future research could thus usefully test this unexpected finding, deepening our understanding of the relationships between CDD programmes and informal revenue generation, between different types of informal taxes, and between informal and formal taxes. Likewise, though we find positive relationships between the matching grant programme and the legitimacy and perceptions of the district government and other local actors, we do not know why these positive effects do not extend to village leaders. We may reasonably expect that individuals perceived that village leaders had a less important direct or indirect brokerage role in the CDD programme, though future research could test this speculation across diverse programmes.

Fourth, while our evidence shows that hybrid financing of public goods through community contributions and NGO funding channelled through the state can have a positive impact on perceptions of the government and formal tax morale, this positive outcome may reasonably depend on satisfaction with the outcomes, while the longevity of the positive association is uncertain. Evidence suggests that dissatisfaction with outcomes, whether in terms of quality of public goods or preference alignment, may negatively affect citizen perceptions of the state (Schmelzle and Stollenwerk 2018; Stollenwerk 2018). Thus, there is some question of how the relationship between matching grants, informal revenue generation and attitudes towards the state may vary according to the desirability of the public goods produced or in contexts with less evidence of inclusive decision-making. At the same time, given the relatively short timeframe involved, the extent to which the boosts that we observe, in terms of positive spill-overs on state and non-state actors, last over time is uncertain.

Finally, and importantly, future research should further explore the equity and distributional implications of matching grants before considering extending this model of financing and service delivery to other regions. As discussed, this impact is particularly important given the overall regressivity of informal revenue generation, and should inform development partners' and policymakers' engagement with informal taxing institutions and formal-informal hybrid financing modalities. Future research could usefully explore the benefits of matching versus equalisation grants, particularly in contexts where local informal revenue generation and contributions to public goods are already prevalent. 


\section{Appendices}

\section{Appendix A DIALOGUE programme}

\section{Figure A1 Project and data collection timeline ${ }^{96}$}

\begin{tabular}{|c|c|c|c|c|c|}
\hline $\begin{array}{l}\text { February } 2018 \\
\text { Communities } \\
\text { submit project } \\
\text { proposals to } \\
\text { DRC; DRC } \\
\text { evaluation of } \\
\text { proposals to } \\
\text { ensure they } \\
\text { meet criteria; } \\
\text { lottery selection } \\
\text { of matching } \\
\text { grant recipients }\end{array}$ & & $\begin{array}{l}\text { April- May } 2018 \\
\text { Community } \\
\text { training on how } \\
\text { to contribute; } \\
\text { community bank } \\
\text { accounts } \\
\text { opened }\end{array}$ & & $\begin{array}{c}\text { September- } \\
\text { December } 2018 \\
\text { Community } \\
\text { development } \\
\text { projects } \\
\text { constructed }\end{array}$ & \\
\hline 0 & 0 & 0 & 0 & 0 & 0 \\
\hline & $\begin{array}{c}\text { March } 2018 \\
\text { Baseline data } \\
\text { collection }\end{array}$ & & $\begin{array}{l}\text { June - } \\
\text { November } \\
\text { 2018: } \\
\text { Community } \\
\text { revenue-raising, } \\
\text { matching grants } \\
\text { released when } \\
\text { revenue-raising } \\
\text { completed }\end{array}$ & & $\begin{array}{c}\text { February } 2019 \\
\text { Endline data } \\
\text { collection }\end{array}$ \\
\hline
\end{tabular}

Figure A2 Example of a (translated) information brochure shared in treatment communities
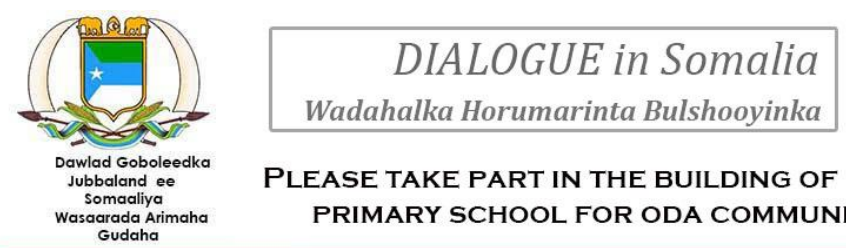

PLEASE TAKE PART IN THE BUILDING OF FIRST PRIMARY SCHOOL FOR ODA COMMUNITY

KINDLY SEND THE AMOUNT YOU CAN CONTRIBUTE TO THE FOLOWING ACCOUNT THROUGH EVC PLUS

\section{*799*32017696*MONEY\#}

FOR MORE INFORMATION, CALL 305 FOR FREE OR VISIT WWW.SOKAAB.COM

\footnotetext{
96 In each community, 4 months was allocated for local revenue-raising, though the start date of revenue-raising and the time that revenue-raising took varied across communities. Accordingly, the period of revenue-raising and project construction are noted as ranges.
} 


\section{Photo A1 Community training (Doloow)}

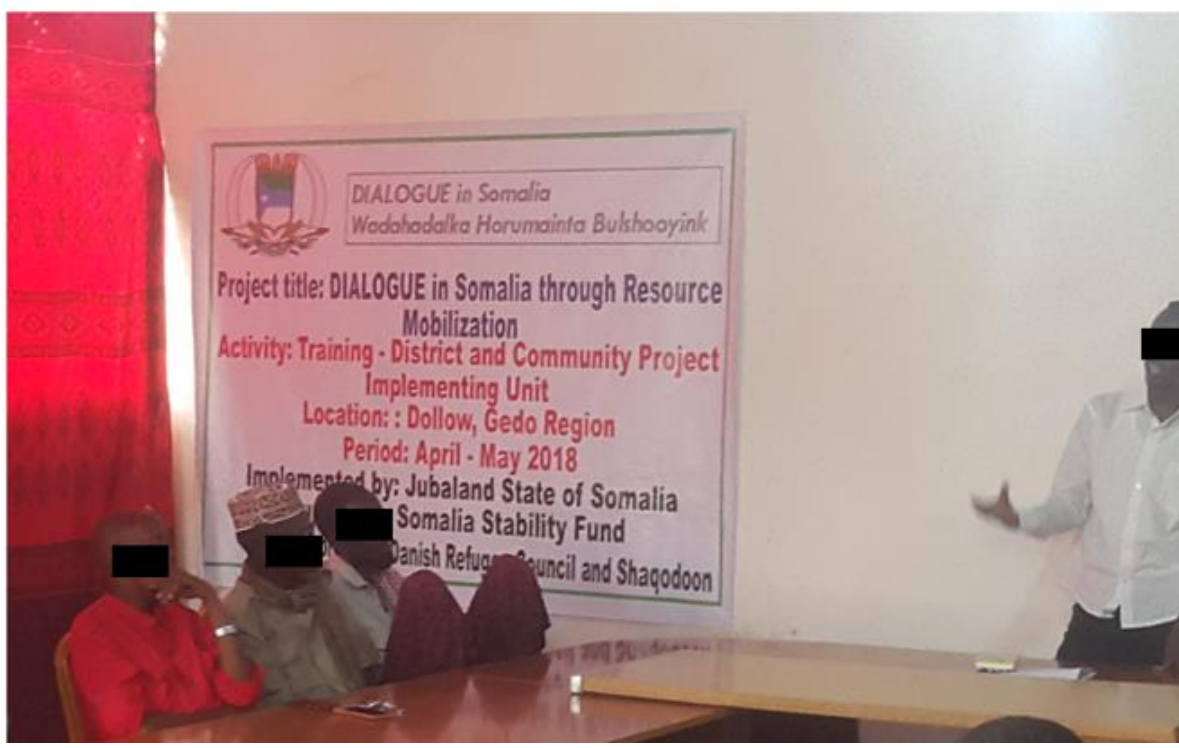

Photo source: Danish Refugee Council Somalia

\section{Note A1 Data collection}

Surveys were conducted by trained enumerators, who were divided into district-level teams, with the majority of enumerators residing in their assigned district. The security team at the DRC was essential for ensuring that the fieldwork was conducted safely. As described, case selection was shaped by the relative security of settlements. The security team provided daily security status reports, with teams of enumerators moving only with the permission of the security team, who approved areas for research and monitored the situation on the ground. When the security situation shifted in any location, data collection was cancelled. At the same time, enumerators and field supervisors were critical in interpreting complex cultural contexts, monitoring social mores, and potential threats of violence. Their embeddedness in local communities (with enumerators selected from each of the three case study districts) ensured access to information of relevance to the security of the research team and research participants through trust-based relationships.

Despite this grounding in the local context, several further precautions were taken to ensure the safety of both the research team and survey respondents. In particular, the survey does not ask questions that could be perceived to be overly political or related to the ongoing statebuilding processes in Jubbaland state and federally. Accordingly, we ask questions about the government at the district level, but not more broadly. At the same time, we do not ask questions directly about informal payments made to or relations with militias and armed groups, including al-Shabaab.

In every situation, we only engaged with research participants after acquiring informed consent, and ensuring that we were able to provide credible guarantees that the research would not cause harm to the research participants. Data security and guarantees of anonymity were central to the research process. Enumerators included both men and women, though field research supervisors in each district were male in order to facilitate the movement of research teams. Having a gender-balanced team was important to ensure the participation of women in the surveys, interviews and focus group discussions, with female enumerators often having greater access to female-headed households. 


\section{Appendix B Community contributions and matching grants}

Table B1 Community development projects supported by matching grants ${ }^{97}$

\begin{tabular}{|c|c|c|c|c|c|c|c|}
\hline $\begin{array}{l}\text { Community or } \\
\text { district level } \\
\text { project (C/D) }\end{array}$ & $\begin{array}{l}\text { Community } \\
\text { code }\end{array}$ & $\begin{array}{l}\text { Number of } \\
\text { settlements } \\
\text { involved }\end{array}$ & $\begin{array}{l}\text { Clan } \\
\text { represent- } \\
\text { ation }\end{array}$ & Project & $\begin{array}{l}\text { Est. HH } \\
\text { population }\end{array}$ & $\begin{array}{l}\text { Community } \\
\text { contributions }\end{array}$ & $\begin{array}{l}\text { Matching } \\
\text { grant }\end{array}$ \\
\hline $\mathrm{C}$ & Luuq & 1 & Same clan & Meeting hall & 155 & 3,400 & 3,400 \\
\hline $\mathrm{C}$ & Luuq & 2 & Multi-clan & $\begin{array}{l}\text { Water } \\
\text { installation }\end{array}$ & 200 & 3,900 & 7,800 \\
\hline $\mathrm{C}$ & Luuq & 1 & Same clan & $\begin{array}{l}\text { School meeting } \\
\text { hall }\end{array}$ & 250 & 3,100 & 3,100 \\
\hline $\mathrm{C}$ & Luuq & 1 & Same clan & Health post & 175 & 10,001 & 10,001 \\
\hline $\mathrm{C}$ & Luuq & 1 & Same clan & $\begin{array}{l}\text { Dam/water } \\
\text { catchment }\end{array}$ & 250 & 5,049 & 5,049 \\
\hline $\mathrm{C}$ & Luuq & 1 & Same clan & Meeting hall & 170 & 2,200 & 2,200 \\
\hline $\mathrm{C}$ & Luuq & 1 & Same clan & Health post & 150 & 2,301 & 2,301 \\
\hline $\mathrm{C}$ & Luug & 1 & Same clan & Health post & 150 & 3,300 & 3,300 \\
\hline $\mathrm{C}$ & Luuq & 1 & Same clan & Meeting hall & 160 & 2,300 & 2,300 \\
\hline $\mathrm{C}$ & Luuq & 1 & Same clan & Primary school & 162 & 1,700 & 1,700 \\
\hline $\mathrm{C}$ & Luuq & 1 & Same clan & Primary school & 150 & 2,100 & 2,100 \\
\hline $\mathrm{C}$ & Luuq & 1 & Same clan & Primary school & 165 & 1,600 & 1,600 \\
\hline $\mathrm{C}$ & Luuq & 1 & Same clan & Meeting hall & 150 & 1,800 & 1,800 \\
\hline $\mathrm{C}$ & Luuq & 2 & Multi-clan & $\begin{array}{l}\text { Meeting hall } \\
\text { with latrines } \\
\text { and fence } \\
\end{array}$ & 200 & 6,500 & 13,000 \\
\hline $\mathrm{C}$ & Dooloow & 2 & Multi-clan & $\begin{array}{l}\text { Health care } \\
(\mathrm{MCH})\end{array}$ & 165 & 6,700 & 13,400 \\
\hline $\mathrm{C}$ & Dooloow & 2 & Same clan & Water & 150 & 4,352 & 8,704 \\
\hline $\mathrm{C}$ & Dooloow & 4 & Multi-clan & $\begin{array}{l}\text { Health care } \\
(\mathrm{MCH})\end{array}$ & 150 & 6,700 & 20,100 \\
\hline $\mathrm{C}$ & Dooloow & 4 & Multi-clan & $\begin{array}{l}\text { Conference } \\
\text { hall }\end{array}$ & 150 & 6,700 & 20,100 \\
\hline $\mathrm{C}$ & Dooloow & 3 & Same clan & School & 150 & 3,400 & 10,200 \\
\hline $\mathrm{C}$ & Beled Xaawo & 4 & Multi-clan & Primary school & 180 & 6,501 & 19,500 \\
\hline $\mathrm{C}$ & Beled Xaawo & 1 & Same clan & $\begin{array}{l}\text { Health care } \\
(\mathrm{MCH})\end{array}$ & 150 & 1,903 & 1,903 \\
\hline $\mathrm{C}$ & Beled Xaawo & 1 & Same clan & Health centre & 160 & 2,433 & 2,433 \\
\hline $\mathrm{C}$ & Beled Xaawo & 1 & Same clan & Health post & 152 & 1,660 & 1,660 \\
\hline $\mathrm{C}$ & Beled Xaawo & 3 & Same clan & Primary school & 200 & 1 & 0 \\
\hline $\mathrm{C}$ & Beled Xaawo & 1 & Same clan & $\begin{array}{l}\text { Primary and } \\
\text { secondary } \\
\text { school }\end{array}$ & 165 & 1,315 & 1,315 \\
\hline $\mathrm{C}$ & Beled Xaawo & 1 & Same clan & Farming inputs & 160 & 9,900 & 9,900 \\
\hline $\mathrm{C}$ & Beled Xaawo & 5 & Multi-clan & $\begin{array}{l}\text { School and } \\
\text { water } \\
\text { installation }\end{array}$ & 190 & 1,859 & 5,577 \\
\hline $\mathrm{C}$ & Beled Xaawo & 1 & Same clan & Primary school & 155 & 3,692 & 3,692 \\
\hline $\mathrm{C}$ & Beled Xaawo & 3 & Same clan & $\begin{array}{l}\text { Water } \\
\text { installation }\end{array}$ & 216 & 6,600 & 19,800 \\
\hline C & Beled Xaawo & 3 & Same clan & $\begin{array}{l}\text { Construction of } \\
\text { primary school }\end{array}$ & 180 & 2 & 0 \\
\hline $\mathrm{D}$ & Luuq & $\mathrm{N} / \mathrm{A}$ & $\mathrm{N} / \mathrm{A}$ & $\begin{array}{l}\text { Airstrip terminal } \\
\text { hall, police } \\
\text { station at } \\
\text { airport }\end{array}$ & & 24,120 & 40,000 \\
\hline $\mathrm{D}$ & Dooloow & $\mathrm{N} / \mathrm{A}$ & $\mathrm{N} / \mathrm{A}$ & $\begin{array}{l}\text { Road } \\
\text { renovation/ } \\
\text { airport }\end{array}$ & & 10,000 & 96,480 \\
\hline $\mathrm{D}$ & Beled Xaawo & $\mathrm{N} / \mathrm{A}$ & $\mathrm{N} / \mathrm{A}$ & $\begin{array}{l}\text { Road } \\
\text { renovation }\end{array}$ & & 10,000 & 40,000 \\
\hline $\mathrm{D}$ & Garbahareey & $\mathrm{N} / \mathrm{A}$ & $\mathrm{N} / \mathrm{A}$ & $\begin{array}{l}\text { Secondary } \\
\text { school fencing }\end{array}$ & & 11,500 & 46,000 \\
\hline $\mathrm{D}$ & Elwak & $\mathrm{N} / \mathrm{A}$ & $\mathrm{N} / \mathrm{A}$ & $\begin{array}{l}\text { Road } \\
\text { renovation }\end{array}$ & & 10,507 & 42,028 \\
\hline $\mathrm{D}$ & Bardera & $\mathrm{N} / \mathrm{A}$ & $\mathrm{N} / \mathrm{A}$ & $\begin{array}{l}\text { Guesthouse } \\
\text { construction }\end{array}$ & & 10,001 & 40,000 \\
\hline $\mathrm{D}$ & Burdhubo & $\mathrm{N} / \mathrm{A}$ & $\mathrm{N} / \mathrm{A}$ & $\begin{array}{l}\text { Road } \\
\text { renovation }\end{array}$ & & 14,403 & 57,557 \\
\hline
\end{tabular}

97 As noted in Section 3, matching grants are more than community contributions in some communities, as the size of the matching grant depended on whether the project involved inter-village and inter-clan collaboration. 
Table B2 DIALOGUE impact on contributions to new projects (community leader survey data)

\begin{tabular}{|c|c|c|c|c|c|c|c|c|}
\hline & (1) & (2) & (3) & (4) & (5) & (6) & (7) & (8) \\
\hline & $\begin{array}{c}\text { Any new } \\
\text { project }\end{array}$ & $\begin{array}{c}\text { Any new } \\
\text { project }\end{array}$ & $\begin{array}{c}\text { HHs \% } \\
\text { contributing }\end{array}$ & $\begin{array}{c}\mathrm{HHs} \% \\
\text { contributing }\end{array}$ & $\begin{array}{l}\text { Log tot. } \\
\text { contribution } \\
\text { (US\$) }\end{array}$ & $\begin{array}{l}\text { Log tot. } \\
\text { contribution } \\
\text { (US\$) }\end{array}$ & $\begin{array}{l}\text { Log avg } \\
\text { contribution } \\
\text { (US\$) }\end{array}$ & $\begin{array}{l}\text { Log avg } \\
\text { contribution } \\
\text { (US\$) }\end{array}$ \\
\hline Dialogue & $0.12^{*}$ & $0.17^{\star \star}$ & $12.19^{* *}$ & $18.03^{* \star *}$ & $1.07^{*}$ & $1.45^{\star \star}$ & 0.14 & 0.16 \\
\hline & $(0.06)$ & $(0.07)$ & $(5.00)$ & $(5.60)$ & (0.61) & $(0.64)$ & $(0.32)$ & $(0.34)$ \\
\hline Controls & No & Yes & No & Yes & No & Yes & No & Yes \\
\hline $\begin{array}{l}\text { Control Y } \\
\text { endline }\end{array}$ & 0.84 & 0.84 & 25.17 & 25.17 & 5.76 & 5.76 & 3.23 & 3.23 \\
\hline R-sq. & 0.038 & 0.204 & 0.061 & 0.283 & 0.033 & 0.272 & 0.002 & 0.157 \\
\hline Obs. & 98 & 98 & 93 & 93 & 92 & 92 & 91 & 91 \\
\hline
\end{tabular}

Standard errors in parentheses. " $p<0.10,{ }^{* *} p<0.05,{ }^{* * *} p<0.01$

\section{Photo B1 Schools constructed in Beled Xaawo and Luuq}

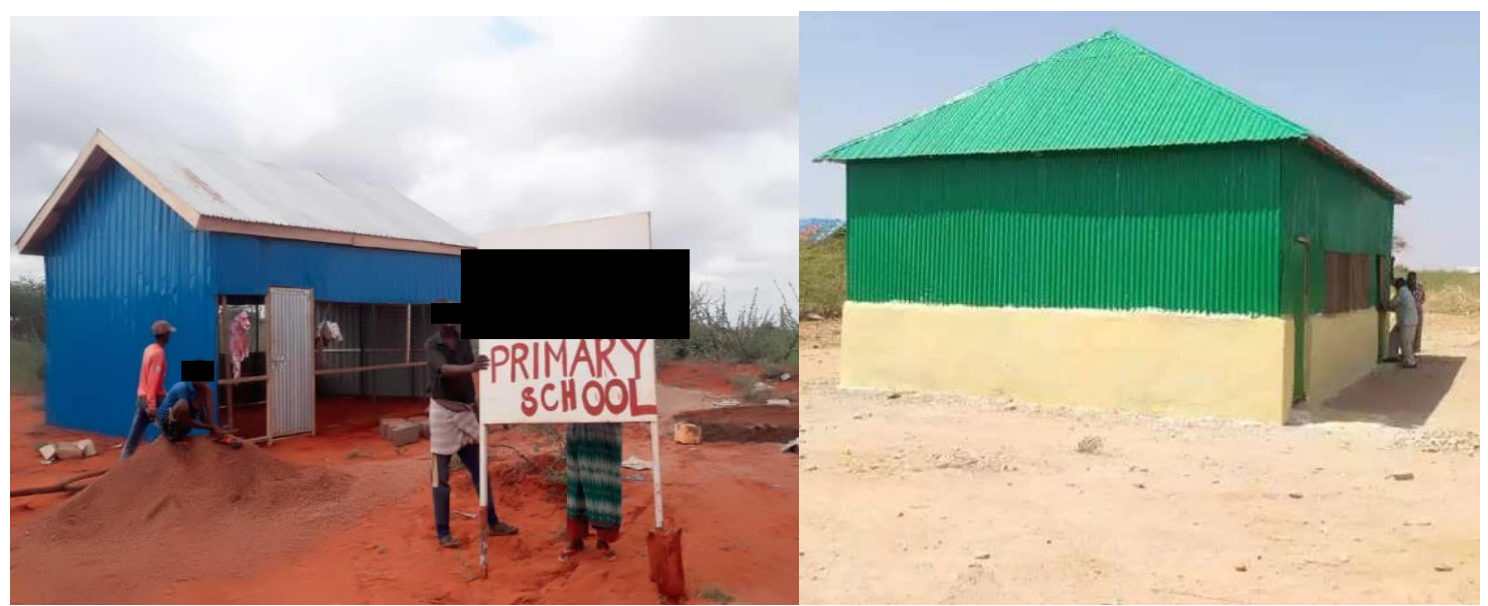

Photo source: Danish Refugee Council Somalia 


\section{Photo B2 Dooloow airport terminal before and after DIALOGUE programme}

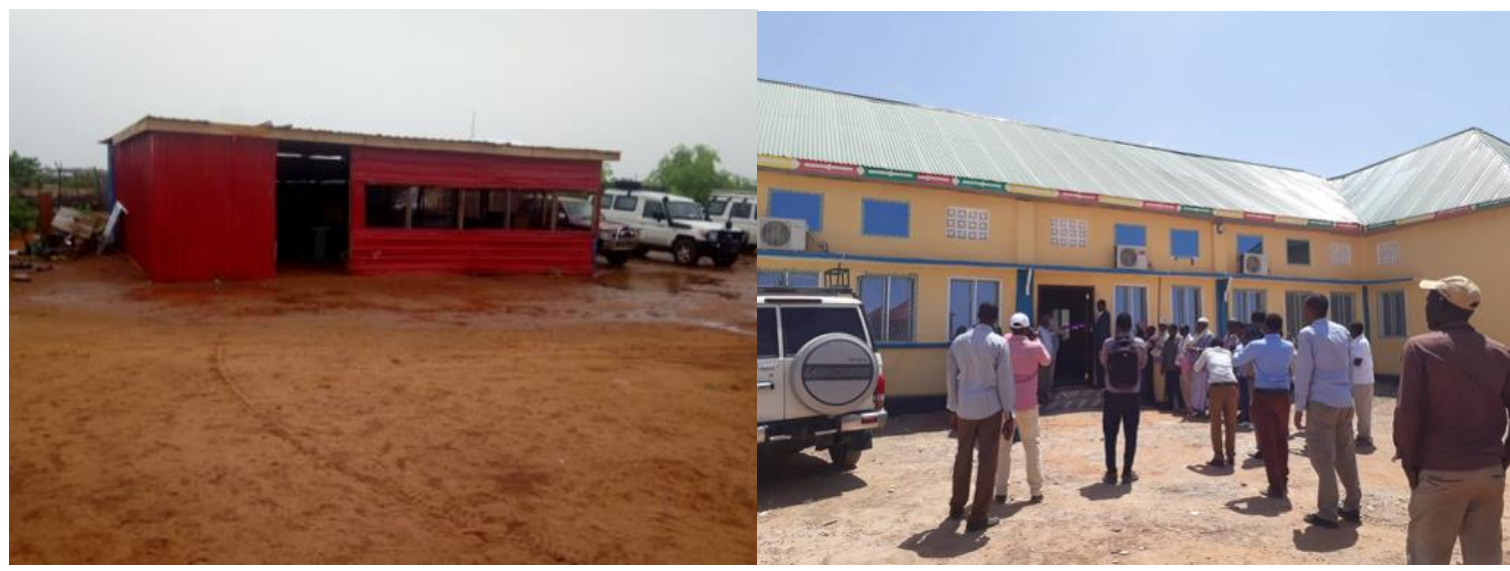

Photo source: Danish Refugee Council Somalia

\section{Appendix C Balance and attrition tables ${ }^{98}$}

\section{Table C1 Sample distribution}

\begin{tabular}{|c|c|c|c|c|c|c|}
\hline \multirow{2}{*}{} & \multicolumn{3}{|c|}{ Number of household surveys } & \multicolumn{3}{c|}{ Number of village leader surveys } \\
\cline { 2 - 7 } & Total & Treatment villages & Control villages & Total & Treatment villages & Control villages \\
\cline { 2 - 7 } & 880 & 439 & 441 & 98 & 48 & 50 \\
\hline Luuq & 159 & 68 & 91 & 25 & 10 & 15 \\
\hline Dooloow & 224 & 143 & 81 & 26 & 17 & 9 \\
\hline Beled Xaawo & 497 & 228 & 269 & 47 & 21 & 26 \\
\hline
\end{tabular}

\section{Table C2 Village characteristics from village leader surveys}

\begin{tabular}{|c|c|c|c|c|c|}
\hline & \multicolumn{2}{|c|}{ Treatment } & \multicolumn{2}{|c|}{ Control } & \multirow[b]{2}{*}{ Difference } \\
\hline & Obs & Mean & Obs & Mean & \\
\hline Daily labor wage & 52 & 133409.94 & 65 & 239114.25 & -105704.30 \\
\hline Price bag of rice & 52 & 1154334.62 & 65 & 2658376.52 & -1504041.91 \\
\hline$\%$ Agriculture & 51 & 48.65 & 64 & 47.81 & 0.83 \\
\hline$\%$ Fishing & 41 & 2.07 & 53 & 2.53 & -0.46 \\
\hline$\%$ Breeding & 47 & 39.43 & 61 & 30.85 & 8.57 \\
\hline$\%$ Small business & 41 & 6.00 & 57 & 5.56 & 0.44 \\
\hline$\%$ Manufacturing & 39 & 1.69 & 53 & 1.60 & 0.09 \\
\hline$\%$ Teacher/nurses/doctors & 38 & 1.68 & 52 & 1.85 & -0.16 \\
\hline$\%$ Services & 38 & 3.05 & 44 & 1.36 & 1.69 \\
\hline$\%$ Gov officials & 33 & 1.94 & 45 & 2.44 & -0.51 \\
\hline$\%$ Other & 35 & 10.29 & 34 & 4.26 & 6.02 \\
\hline$N$ & 117 & & & & \\
\hline
\end{tabular}

\footnotetext{
${ }^{98}$ Approximate exchange rate: US $\$ 1$ = So.Sh. 559.
} 
Table C3 Household economic situation from individual surveys

\begin{tabular}{|c|c|c|c|c|c|}
\hline & \multicolumn{2}{|c|}{ Treatment } & \multicolumn{2}{|c|}{ Control } & \multirow[b]{2}{*}{ Difference } \\
\hline & Obs & Mean & Obs & Mean & \\
\hline No job & 614 & 0.22 & 683 & 0.29 & $-0.07^{* * *}$ \\
\hline Agriculture & 614 & 0.26 & 683 & 0.26 & -0.01 \\
\hline Pastoralism & 614 & 0.26 & 683 & 0.36 & $-0.10^{* * *}$ \\
\hline Fishing & 614 & 0.01 & 683 & 0.01 & 0.00 \\
\hline Casual labor & 614 & 0.30 & 683 & 0.27 & 0.03 \\
\hline Hunting & 614 & 0.00 & 683 & 0.00 & 0.00 \\
\hline Paid housework/childcare & 614 & 0.02 & 683 & 0.02 & 0.01 \\
\hline Selling goods & 614 & 0.01 & 683 & 0.01 & -0.00 \\
\hline Own business & 614 & 0.03 & 683 & 0.03 & 0.00 \\
\hline Salaried private sector & 614 & 0.01 & 683 & 0.01 & 0.00 \\
\hline Salaried public sector & 614 & 0.00 & 683 & 0.00 & 0.00 \\
\hline Employee village council & 614 & 0.00 & 683 & 0.00 & 0.00 \\
\hline Remittances & 614 & 0.00 & 683 & 0.00 & 0.00 \\
\hline Monthly earnings cash & 554 & 2111910.57 & 603 & 1118553.27 & 993357.30 \\
\hline Monthly earnings kind & 494 & 41473.10 & 522 & 23140.86 & 18332.23 \\
\hline Looking for a job & 138 & 0.64 & 196 & 0.58 & 0.06 \\
\hline$N$ & 1297 & & & & \\
\hline
\end{tabular}

\section{Table C4 Formal taxation from individual surveys}

\begin{tabular}{lccccc}
\hline & \multicolumn{3}{c}{ Treatment } & \multicolumn{2}{c}{ Control } \\
\cline { 2 - 6 } & Obs & Mean & Obs & Mean & Difference \\
\hline Business Taxes & 614 & 0.023 & 683 & 0.018 & 0.005 \\
Income Tax & 614 & 0.020 & 683 & 0.013 & 0.006 \\
Registration of companies & 614 & 0.008 & 683 & 0.020 & $-0.012^{*}$ \\
License/registration of vehicles & 614 & 0.011 & 683 & 0.009 & 0.003 \\
Road Tax & 614 & 0.011 & 683 & 0.009 & 0.003 \\
Livestock Tax & 614 & 0.181 & 683 & 0.165 & 0.015 \\
Land Tax & 614 & 0.020 & 683 & 0.018 & 0.002 \\
Checkpoint fees & 614 & 0.007 & 683 & 0.023 & $-0.017^{* *}$ \\
Fees to private providers of services & 614 & 0.033 & 683 & 0.025 & 0.008 \\
Document/ Passport/visa charges & 614 & 0.002 & 683 & 0.010 & $-0.009^{* *}$ \\
Other & 614 & 0.002 & 683 & 0.003 & -0.001 \\
\hline$N$ & 1297 & & & & \\
\hline${ }^{*} p<0.1,{ }^{* *} p<0.05,{ }^{* * *} p<0.01$ & & & & &
\end{tabular}




\begin{tabular}{lccccc}
\hline & \multicolumn{3}{c}{ Treatment } & \multicolumn{3}{c}{ Control } \\
\cline { 2 - 6 } & Obs & Mean & Obs & Mean & Difference \\
\hline Town cleaning & 614 & 0.19 & 683 & 0.15 & $0.04^{*}$ \\
Communal labour & 614 & 0.08 & 683 & 0.06 & 0.02 \\
Religious contribution & 614 & 0.32 & 683 & 0.34 & -0.02 \\
Group labour to fix a house/roof & 614 & 0.07 & 683 & 0.07 & 0.00 \\
Labour contributions to a village leader & 614 & 0.07 & 683 & 0.07 & -0.01 \\
Contributions to schools or teachers & 611 & 0.07 & 669 & 0.06 & 0.01 \\
Community development project & 614 & 0.07 & 683 & 0.06 & 0.00 \\
Funeral contributions & 614 & 0.30 & 683 & 0.31 & -0.01 \\
Clan contribution (Qaaraan) & 614 & 0.57 & 683 & 0.53 & 0.04 \\
Blood compensation (Diyya) & 614 & 0.45 & 683 & 0.51 & $-0.05^{*}$ \\
Clan debt relief & 614 & 0.20 & 683 & 0.21 & -0.01 \\
Conflict resolution processes & 614 & 0.17 & 683 & 0.20 & -0.03 \\
Social payment & 614 & 0.21 & 683 & 0.21 & -0.00 \\
Other & 614 & 0.02 & 683 & 0.02 & -0.01 \\
\hline$N$ & 1297 & & & & \\
\hline${ }^{*} p<0.1,{ }^{* *} p<0.05,{ }^{* * *} p<0.01$ & & & & &
\end{tabular}

Table C6 Attrition: household survey

\begin{tabular}{|c|c|c|c|c|c|}
\hline & \multicolumn{2}{|c|}{ Non-attrited } & \multicolumn{2}{|c|}{ Attrited } & \multirow[b]{2}{*}{ Difference } \\
\hline & Mean & Obs. & Mean & Obs. & \\
\hline & \multicolumn{5}{|c|}{ Demographics } \\
\hline Dialogue & 391 & 0.45 & 692 & 0.48 & -0.03 \\
\hline Female & 267 & 0.42 & 457 & 0.44 & -0.01 \\
\hline Education Yes & 267 & 0.27 & 457 & 0.34 & $-0.07^{*}$ \\
\hline Darod Marehan & 267 & 0.93 & 457 & 0.94 & -0.02 \\
\hline Use M-money & 366 & 0.62 & 607 & 0.42 & $0.19^{* * *}$ \\
\hline HH size & 383 & 5.60 & 685 & 5.13 & $0.47^{* *}$ \\
\hline No job & 391 & 0.24 & 692 & 0.28 & -0.04 \\
\hline Agriculture & 391 & 0.26 & 692 & 0.29 & -0.03 \\
\hline \multirow[t]{2}{*}{ Pastoralism } & 391 & 0.28 & 692 & 0.30 & -0.02 \\
\hline & \multicolumn{5}{|c|}{ Location } \\
\hline Dollow & 391 & 0.16 & 692 & 0.28 & $-0.11^{* * *}$ \\
\hline Luuq & 391 & 0.23 & 692 & 0.25 & -0.02 \\
\hline Belet-Hawa & 391 & 0.61 & 692 & 0.48 & $0.13^{* \ldots *}$ \\
\hline \multirow[t]{2}{*}{ Rural } & 391 & 1.98 & 692 & 1.98 & 0.01 \\
\hline & \multicolumn{5}{|c|}{ Assistance received } \\
\hline Lack of food or water & 383 & 0.13 & 685 & 0.13 & -0.00 \\
\hline \multirow[t]{2}{*}{ Health emergency } & 383 & 0.09 & 685 & 0.11 & -0.02 \\
\hline & \multicolumn{5}{|c|}{ Contributions } \\
\hline Livestock Tax & 391 & 0.08 & 692 & 0.21 & $-0.13^{* * *}$ \\
\hline \multirow[t]{2}{*}{ IRG above median } & 383 & 0.28 & 685 & 0.37 & $-0.09 * *$ \\
\hline & \multicolumn{5}{|c|}{ Attitudes and perceptions } \\
\hline Satisf. Public Services & 158 & 3.30 & 265 & 2.54 & $0.76^{* * *}$ \\
\hline District legitimacy & 373 & 0.45 & 656 & 0.53 & $-0.08^{* *}$ \\
\hline Village council legitimacy & 376 & 0.69 & 683 & 0.76 & $-0.07^{* * *}$ \\
\hline Clan elders legitimacy & 377 & 0.65 & 682 & 0.75 & $-0.10^{* * *}$ \\
\hline Rel. leaders legitimacy & 374 & 0.62 & 666 & 0.74 & $-0.12^{* * *}$ \\
\hline District trust & 375 & 0.55 & 665 & 0.66 & $-0.12^{* \cdots}$ \\
\hline Village council trust & 385 & 0.96 & 684 & 0.94 & 0.02 \\
\hline Clan elders trust & 385 & 0.91 & 687 & 0.92 & -0.01 \\
\hline Rel. leaders trust & 377 & 0.87 & 653 & 0.89 & -0.02 \\
\hline$N$ & 1083 & & & & \\
\hline
\end{tabular}


Table C7 Attrition: community leader survey

\begin{tabular}{|c|c|c|c|c|c|}
\hline & \multicolumn{2}{|c|}{ Non attrited } & \multicolumn{2}{|c|}{ Attrited } & \multirow[b]{2}{*}{ Difference } \\
\hline & Obs. & Mean & Obs. & Mean & \\
\hline Treated & 98 & 0.49 & 9 & 0.67 & -0.18 \\
\hline Dollow & 98 & 0.26 & 9 & 0.00 & $0.26^{*}$ \\
\hline Luuq & 98 & 0.26 & 9 & 0.22 & 0.03 \\
\hline Belet-Hawa & 98 & 0.49 & 9 & 0.78 & $-0.29^{*}$ \\
\hline Daily labor wage & 97 & 156465.85 & 9 & 145916.67 & 10549.18 \\
\hline Price bag of rice & 97 & 1208734.54 & 9 & 635305.56 & 573428.98 \\
\hline$\%$ Agriculture & 98 & 50.47 & 8 & 40.12 & 10.34 \\
\hline$\%$ Breeding & 93 & 33.39 & 7 & 54.29 & $-20.90^{*}$ \\
\hline$\%$ Manufacturing & 79 & 1.15 & 6 & 0.00 & 1.15 \\
\hline$\%$ Small business & 83 & 3.98 & 7 & 18.86 & $-14.88^{* * *}$ \\
\hline Dist. district capital (hrs) & 97 & 1.41 & 9 & 1.36 & 0.05 \\
\hline Qaraan/Clan contribution & 98 & 0.73 & 9 & 0.78 & -0.04 \\
\hline Diyya/Blood compensation & 98 & 0.56 & 9 & 0.56 & 0.01 \\
\hline Zakaat/Religious contribution & 98 & 0.50 & 9 & 0.44 & 0.06 \\
\hline Business Tax & 98 & 0.04 & 9 & 0.22 & $-0.18^{* *}$ \\
\hline Womens' Associations Yes (\%) & 98 & 0.44 & 9 & 0.44 & -0.01 \\
\hline Youth associations Yes (\%) & 98 & 0.35 & 9 & 0.22 & 0.12 \\
\hline Farmers' associations Yes (\%) & 98 & 0.39 & 9 & 0.11 & 0.28 \\
\hline Mosque Yes (\%) & 98 & 0.40 & 9 & 0.33 & 0.06 \\
\hline \# pub. meetings & 98 & 9.01 & 9 & 7.44 & 1.57 \\
\hline$\%$ women in meetings & 83 & 30.22 & 8 & 40.12 & -9.91 \\
\hline$N$ & 107 & & & & \\
\hline
\end{tabular}

\section{Appendix D Descriptive data, settlements}

\section{Table D1 Settlement-level data}

\begin{tabular}{|l|l|l|l|l|l|l|}
\hline & $\mathbf{N}$ & Mean & St. dev & p25 & Median & p75 \\
\hline Rural village & & & & & & \\
\hline Population & 117 & .97 & 0.16 & 1 & 1 & 1 \\
\hline $\begin{array}{l}\text { Darod Marehan as } \\
\text { dominant clan }\end{array}$ & 117 & 1426.4 & 5686.4 & 240 & 476 & 900 \\
\hline Agriculture & 115 & .8 & .4 & 1 & 1 & 1 \\
\hline Fishing & 94 & 2.3 & 26.4 & 30 & 50 & 70 \\
\hline Breeding & 108 & 34.6 & 28 & 0 & 0 & 0 \\
\hline $\begin{array}{l}\text { Small business/petty } \\
\text { trading }\end{array}$ & 98 & 5.7 & 12.9 & 0 & 0 & 60 \\
\hline Has a primary school & 117 & .4 & .5 & 0 & 0 & 5 \\
\hline $\begin{array}{l}\text { Has a public } \\
\text { hospital/clinic }\end{array}$ & 117 & .1 & .3 & 0 & 0 & 1 \\
\hline $\begin{array}{c}\text { \# public meetings last } \\
\text { year }\end{array}$ & 116 & 8 & 10.4 & 2 & 3 & 0 \\
\hline $\begin{array}{l}\text { Attendance in last } \\
\text { public meeting }\end{array}$ & 97 & 899.1 & 5450.1 & 35 & 50 & 10 \\
\hline $\begin{array}{c}\text { Has a public notice } \\
\text { board visible }\end{array}$ & 117 & .1 & .3 & 0 & 0 & 150 \\
\hline Male village leader & 117 & .96 & .20 & 1 & 1 & 0 \\
\hline $\begin{array}{l}\text { Village leader tenure } \\
\text { (years) }\end{array}$ & 117 & 6.8 & 5.7 & 4 & 5 & 1 \\
\hline
\end{tabular}




\section{Appendix E Context of study}

Figure E1 Number of conflict events per year by district in Gedo region, 2010-202099

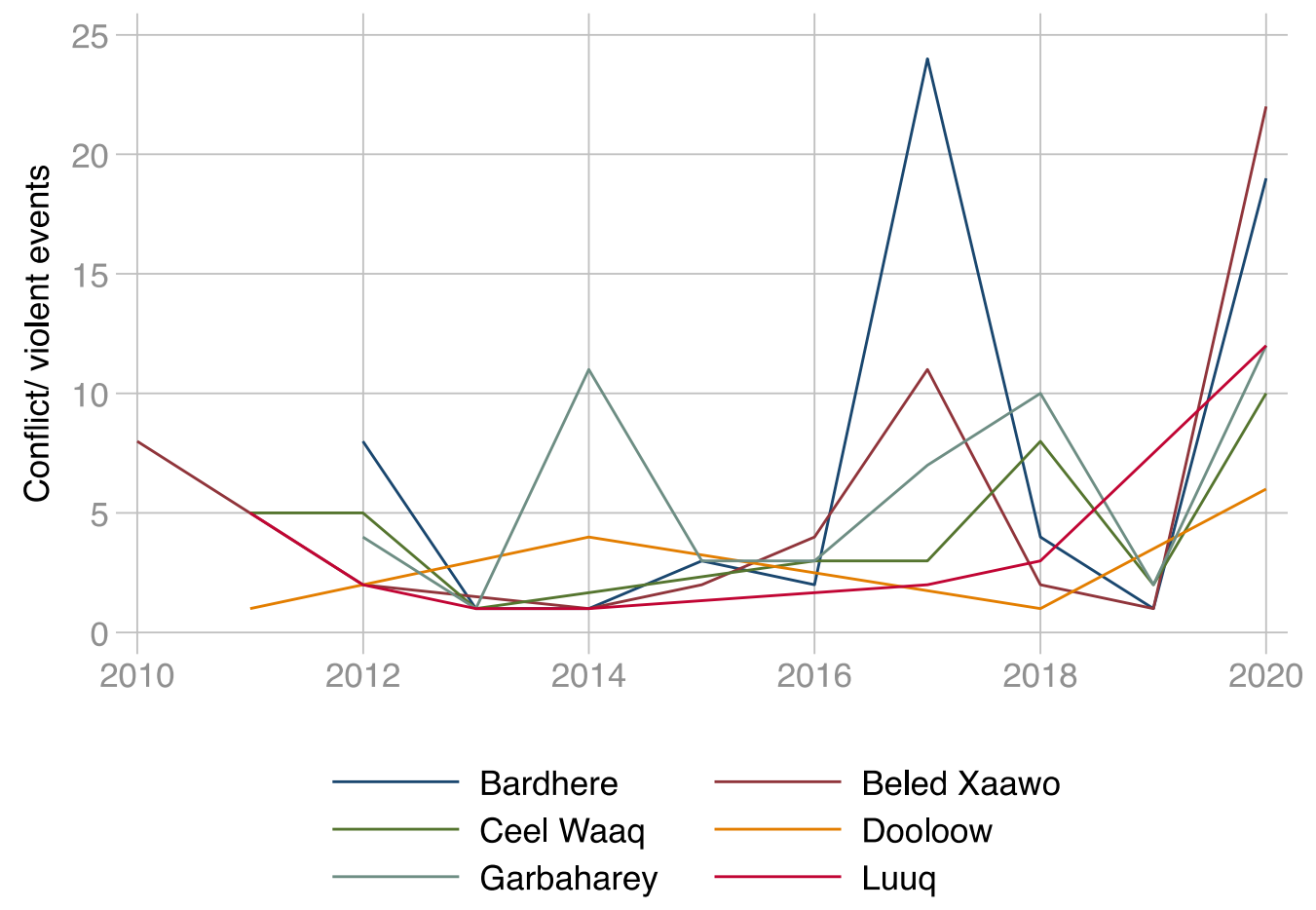

Data source: ACLED (2020).

99 Conflict events include, as classified by ACLED, battles, explosions/remote violence, riots and violence against civilians. Gedo officially comprises six districts, though Buurdhuubo is sometimes considered a separate seventh district. However, separate data was not found for Buurdhuubo district. 
Appendix F DIALOGUE impact on project outcomes

Figure F1 New community development projects

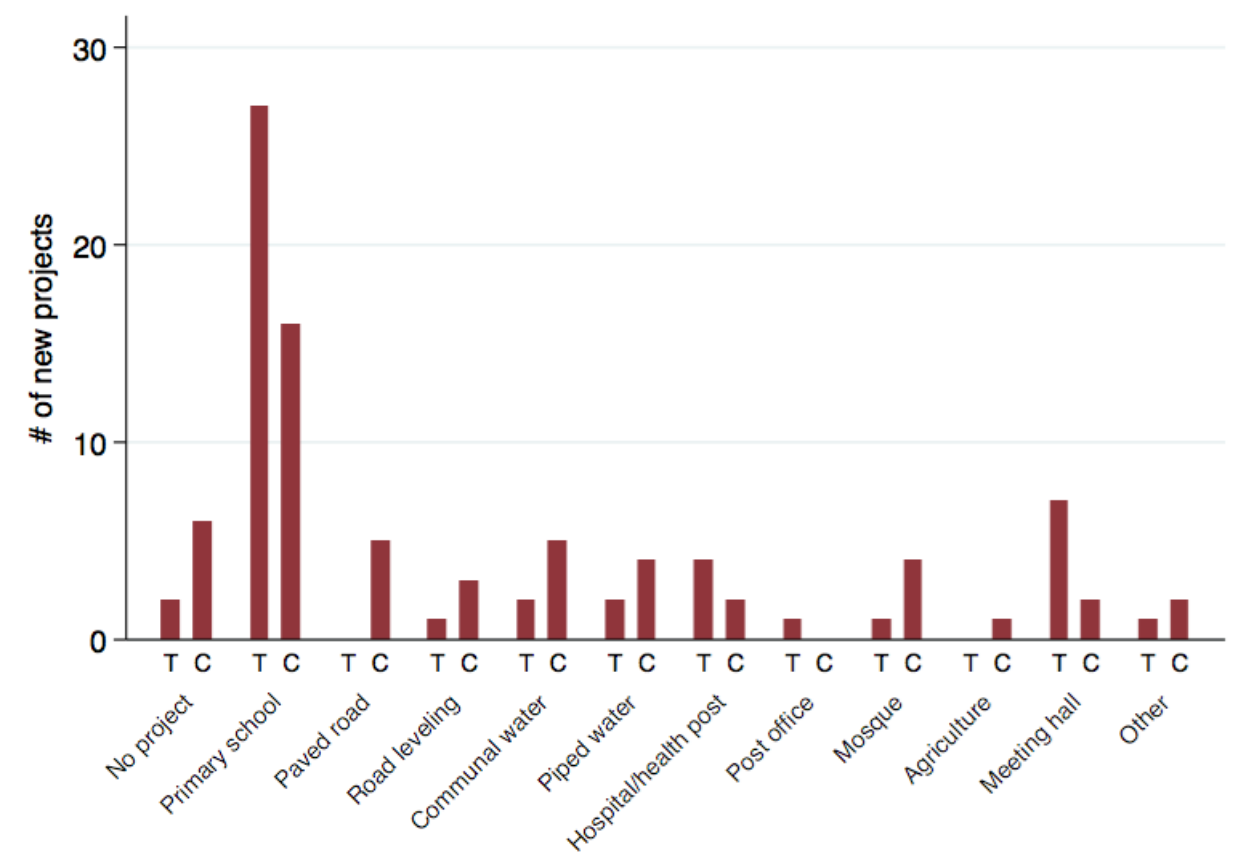

Figure F2 Preferences for community development projects at baseline

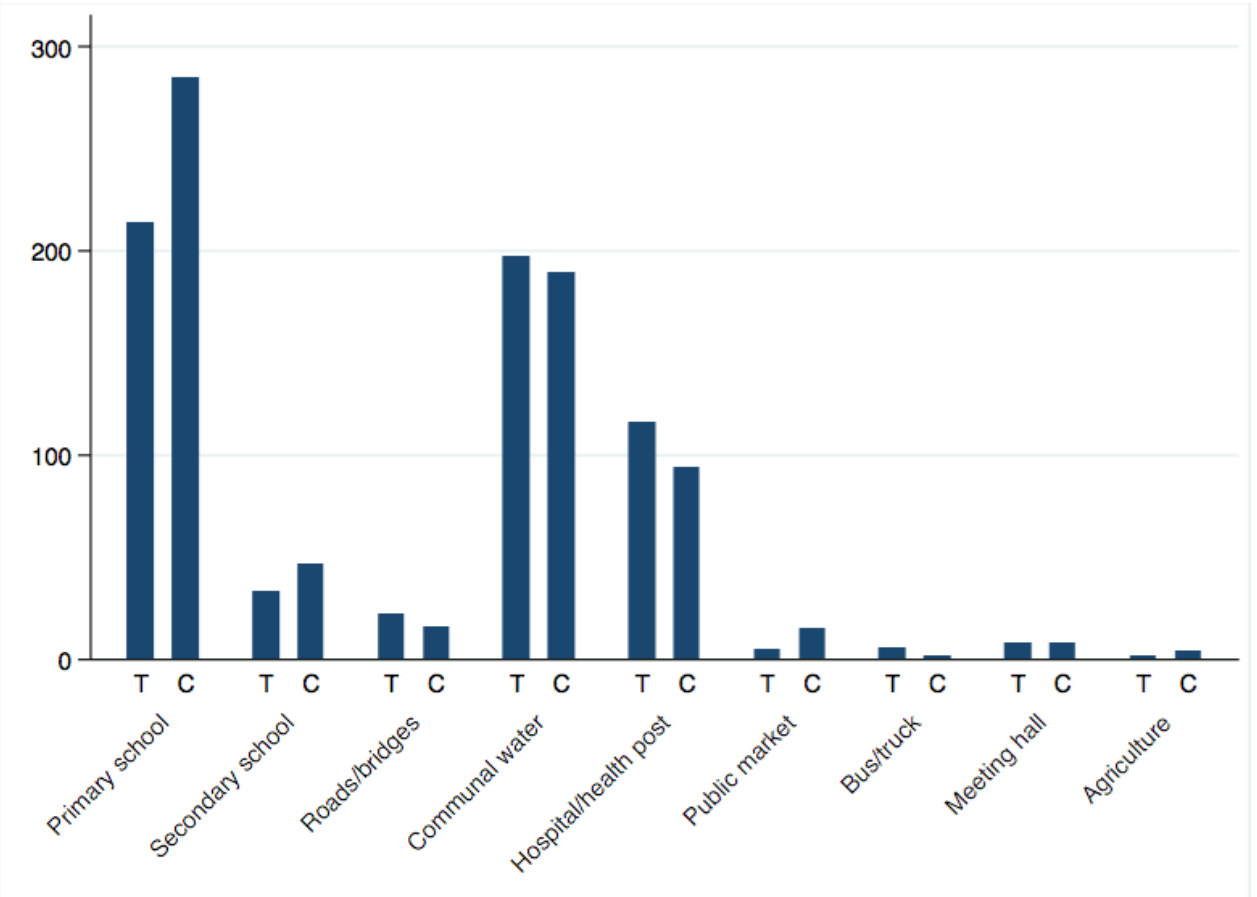




\section{Figure F3 Observational data on the quality of community projects ${ }^{100}$}

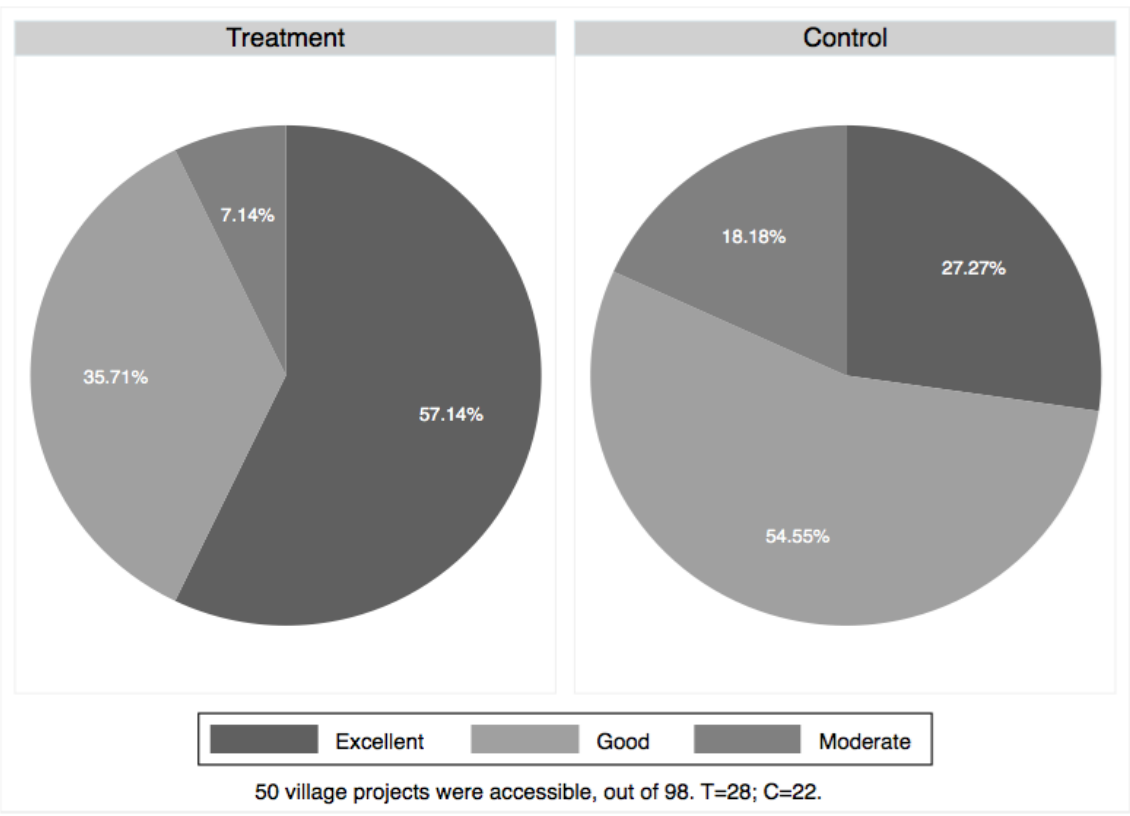

Figure F4 Household (top) versus leader (bottom) perceptions of clan decision-making

Do you agree or disagree that the following actors involve you in the decision making processes in your community?

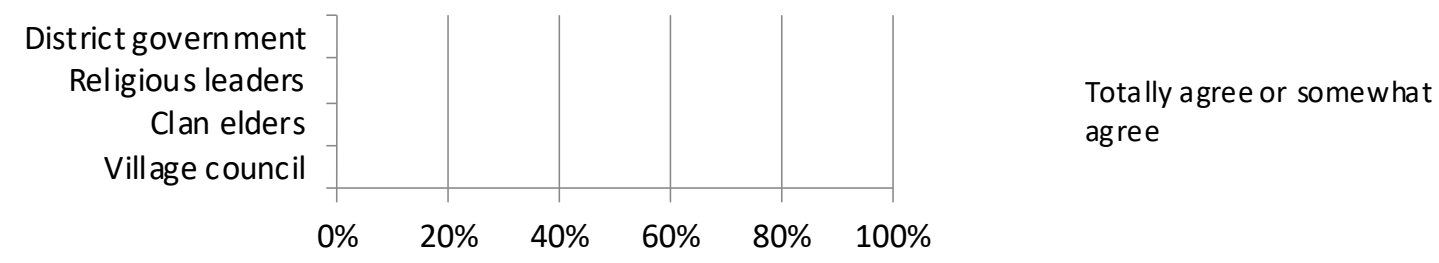

How much authority does the clan in power have to make decisions on behalf of the community?

\begin{tabular}{|c|c|c|c|c|c|c|}
\hline $10 \%$ & $20 \%$ & $30 \%$ & $40 \%$ & $50 \%$ & $60 \%$ & $70 \%$ \\
\hline
\end{tabular}

- Total authority Cannot make decisions without influence of community members

100 Observational data was only collected in those communities that remained safe enough to be accessible, where access to projects was granted by community leaders, and where projects were close enough to enumeration sites to be accessible. In treatment communities, enumerators observed $58 \%$ and $44 \%$ of community projects in treatment and control communities, respectively. The survey question is: 'Assess the overall quality/accessibility of the project'. 
Table F1 New community development project indicators

\begin{tabular}{|c|c|c|c|c|c|c|c|c|}
\hline & (1) & (2) & (3) & (4) & (5) & (6) & (7) & (8) \\
\hline & $\begin{array}{c}\text { Completed } \\
\text { (L) }\end{array}$ & $\begin{array}{c}\text { Completed } \\
\text { (L) }\end{array}$ & $\begin{array}{l}\text { Access } \\
\text { (E) }\end{array}$ & $\begin{array}{l}\text { Access } \\
\text { (E) }\end{array}$ & $\begin{array}{l}\text { Completed } \\
\text { (E) }\end{array}$ & $\begin{array}{l}\text { Completed } \\
\text { (E) }\end{array}$ & $\begin{array}{l}\text { High } \\
\text { quality } \\
\text { (E) }\end{array}$ & $\begin{array}{l}\text { High } \\
\text { quality } \\
\text { (E) }\end{array}$ \\
\hline Dialogue & -0.05 & -0.01 & 0.14 & $0.19^{*}$ & 0.00 & 0.18 & $0.30^{* *}$ & $0.47^{*+*}$ \\
\hline & $(0.09)$ & $(0.11)$ & $(0.10)$ & $(0.11)$ & $(0.11)$ & $(0.14)$ & $(0.14)$ & $(0.14)$ \\
\hline Controls & No & Yes & No & Yes & No & Yes & No & Yes \\
\hline $\begin{array}{l}\text { Control Y } \\
\text { endline }\end{array}$ & 0.76 & 0.76 & 0.44 & 0.44 & 0.82 & 0.82 & 0.27 & 0.27 \\
\hline R-sq. & 0.003 & 0.171 & 0.021 & 0.314 & 0.000 & 0.323 & 0.089 & 0.368 \\
\hline Observations & 98 & 98 & 98 & 98 & 50 & 50 & 50 & 50 \\
\hline
\end{tabular}

Standard errors in parentheses

${ }^{*} p<0.10,{ }^{* *} p<0.05,{ }^{, * *} p<0.01$

\section{Appendix G DIALOGUE impact on engagement}

\section{Table G1 DIALOGUE impact on engagement with state ${ }^{101}$}

\begin{tabular}{|c|c|c|c|c|}
\hline & (1) & (2) & (3) & (4) \\
\hline & Interactions & Interactions & Inclusivity & Inclusivity \\
\hline \multirow[t]{2}{*}{ Dialogue } & 0.01 & 0.01 & $0.10^{*}$ & 0.10 \\
\hline & $(0.04)$ & $(0.05)$ & $(0.06)$ & $(0.06)$ \\
\hline Baseline outcome & No & Yes & No & Yes \\
\hline Controls & $\mathrm{No}$ & Yes & No & Yes \\
\hline & & & & \\
\hline Village FE & Yes & Yes & Yes & Yes \\
\hline Control Y endline & 0.10 & 0.10 & 0.59 & 0.59 \\
\hline Control $\mathrm{Y}$ baseline & 0.07 & 0.07 & 0.00 & 0.39 \\
\hline R-sq. & 0.331 & 0.346 & 0.438 & 0.446 \\
\hline Observations & 856 & 856 & 878 & 878 \\
\hline
\end{tabular}

Standard errors in parentheses. ${ }^{*} p<0.10,{ }^{* *} p<0.05,{ }^{* * *} p<0.01$

Table G2 DIALOGUE impact on engagement with non-state actors ${ }^{102}$

\begin{tabular}{|c|c|c|c|c|c|c|c|c|c|c|}
\hline & (1) & (2) & (3) & (4) & (5) & (6) & (7) & (8) & (9) & (10) \\
\hline & $\begin{array}{c}\text { Village } \\
\text { council } \\
- \text { interactions }\end{array}$ & $\begin{array}{c}\text { Village } \\
\text { council - } \\
\text { interactions }\end{array}$ & $\begin{array}{c}\text { Village } \\
\text { council - } \\
\text { inclusivity }\end{array}$ & $\begin{array}{c}\text { Village } \\
\text { council - } \\
\text { inclusivity }\end{array}$ & $\begin{array}{c}\text { Clan elders } \\
- \\
\text { interactions }\end{array}$ & $\begin{array}{c}\text { Clan elders } \\
- \\
\text { interactions }\end{array}$ & $\begin{array}{c}\text { Clan } \\
\text { elders - } \\
\text { inclusivity }\end{array}$ & $\begin{array}{c}\text { Clan } \\
\text { elders - } \\
\text { inclusivity }\end{array}$ & $\begin{array}{l}\text { Religious } \\
\text { leaders - } \\
\text { inclusivity }\end{array}$ & $\begin{array}{l}\text { Religious } \\
\text { leaders - } \\
\text { inclusivity }\end{array}$ \\
\hline & $(0.05)$ & $(0.05)$ & $(0.06)$ & $(0.06)$ & $(0.05)$ & $(0.05)$ & $(0.07)$ & $(0.07)$ & $(0.06)$ & $(0.06)$ \\
\hline & $\mathrm{No}$ & & & & & & & & & Ya \\
\hline $\begin{array}{l}\text { Basellne } \\
\text { outcome }\end{array}$ & No & No & No & Yes & No & Yes & No & Yes & No & Yes \\
\hline Controls & No & Yes & No & Yes & No & Yes & No & Yes & No & Yes \\
\hline Village FE & Yes & Yes & Yes & Yes & Yes & Yes & Yes & Yes & Yes & Yes \\
\hline $\begin{array}{l}\text { Control } \\
\text { endline }\end{array}$ & 0.26 & 0.26 & 0.75 & 0.75 & 0.30 & 0.30 & 0.71 & 0.71 & 0.67 & 0.67 \\
\hline $\begin{array}{l}\text { Control } \\
\text { baseline }\end{array}$ & & & 0.72 & 0.72 & 0.71 & 0.67 & 0.68 & 0.68 & 0.70 & 0.70 \\
\hline R-sq. & 0.392 & 0.402 & 0.219 & 0.240 & 0.374 & 0.381 & 0.273 & 0.286 & 0.355 & 0.366 \\
\hline Observations & 867 & 867 & 874 & 874 & 867 & 867 & 876 & 876 & 847 & 847 \\
\hline
\end{tabular}

Standard errors in parentheses. ${ }^{*} p<0.10,{ }^{* *} p<0.05,{ }^{* * *} p<0.01$

\footnotetext{
101 Survey questions: (i) in col. 1-2, 'Please tell me whether you, personally, have done any of these things during the past year: Had any interaction with a district council official or tax collector?'; (ii) in col. 3-4, 'Please tell me whether you, personally, have done any of these things during the past year. Had any interaction with a central government official or tax collector?'; (iii) in col. 5-6, 'The district government involves me in the decision-making process in my community' (likert-type question on agreement with the statement).

102 Survey questions on interactions and inclusivity mirror those for state actors described in the previous footnote.
} 


\section{Appendix H DIALOGUE impact on performance}

Table H1 DIALOGUE impact on perceptions of the district government ${ }^{103}$

\begin{tabular}{|l|c|c|c|c|c|c|}
\hline & $(\mathbf{1}$ & $\mathbf{( 2 )}$ & $\mathbf{( 3 )}$ & $\mathbf{( 4 )}$ & $\mathbf{( 5 )}$ & $\mathbf{( 6 )}$ \\
\hline & Transparency & Transparency & Trust & Trust & Performance & Performance \\
\hline Dialogue & $0.14^{* *}$ & $0.13^{* *}$ & $0.15^{* *}$ & $0.15^{* *}$ & $0.12^{* *}$ & $0.11^{* *}$ \\
\hline & $(0.06)$ & $(0.06)$ & $(0.07)$ & $(0.07)$ & $(0.05)$ & Yes \\
\hline $\begin{array}{l}\text { Baseline } \\
\text { outcome }\end{array}$ & No & Yes & No & Yes & No & Yes \\
\hline Controls & No & Yes & No & Yes & No & Yes \\
\hline Village FE & Yes & Yes & Yes & Yes & Yes & 0.35 \\
\hline $\begin{array}{l}\text { Control Y } \\
\text { endline }\end{array}$ & 0.35 & 0.35 & 0.76 & 0.76 & 0.35 & 0.33 \\
\hline $\begin{array}{l}\text { Control Y } \\
\text { baseline }\end{array}$ & 0.08 & 0.08 & 0.55 & 0.55 & 0.33 & 833 \\
\hline R-sq. & 0.405 & 0.410 & 0.384 & 0.395 & 0.500 & 0.513 \\
\hline Observations & 804 & 804 & 859 & 859 & 833 & 83 \\
\hline
\end{tabular}

Standard errors in parentheses. " $p<0.10,{ }^{* *} p<0.05,{ }^{* * *} p<0.01$

Table H2 DIALOGUE impact on perceptions of the village council

\begin{tabular}{|l|c|c|c|c|c|c|}
\hline & $(\mathbf{1}$ & $\mathbf{( 2 )}$ & $\mathbf{( 3 )}$ & $\mathbf{( 4 )}$ & $\mathbf{( 5 )}$ & $\mathbf{( 6 )}$ \\
\hline & Transparency & Transparency & Trust & Trust & Performance & Performance \\
\hline Dialogue & -0.09 & -0.08 & -0.03 & -0.03 & $-0.16^{* *}$ & $-0.17^{* *}$ \\
\hline & $(0.07)$ & $(0.06)$ & $(0.03)$ & $(0.03)$ & $(0.07)$ & $(0.07)$ \\
\hline Baseline outcome & & & & & & \\
\hline & No & Yes & No & Yes & No & Yes \\
\hline Controls & & & & & & \\
\hline & No & Yes & No & Yes & No & Yes \\
\hline Village FE & Yes & & & & & \\
\hline Control Y endline & 0.47 & 0.47 & 0.96 & 0.96 & 0.57 & 0.57 \\
\hline Control Y baseline & 0.20 & 0.20 & 0.95 & 0.95 & 0.71 & 0.71 \\
\hline R-sq. & 0.315 & 0.570 & 0.194 & 0.198 & 0.330 & 0.341 \\
\hline Observations & 819 & 819 & 877 & 877 & 857 & 857 \\
\hline
\end{tabular}

Standard errors in parentheses. " $p<0.10,{ }^{* *} p<0.05,{ }^{* * *} p<0.01$

Table H3 DIALOGUE impact on perceptions of religious leaders

\begin{tabular}{|l|c|c|c|c|c|c|}
\hline & $(\mathbf{1})$ & $(\mathbf{2})$ & $\mathbf{( 3 )}$ & $\mathbf{( 4 )}$ & $\mathbf{( 5 )}$ & $\mathbf{( 6 )}$ \\
\hline & Transparency & Transparency & Trust & Trust & Performance & Performance \\
\hline Dialogue & 0.08 & 0.08 & $0.12^{* *}$ & $0.13^{* *}$ & $0.12^{*}$ & $0.13^{*}$ \\
\hline & $(0.06)$ & $(0.06)$ & $(0.05)$ & $(0.05)$ & $(0.06)$ & $(0.06)$ \\
\hline Baseline outcome & No & Yes & No & Yes & No & Yes \\
\hline & & & & & & \\
\hline Controls & No & Yes & No & Yes & No & Yes \\
\hline & & & & & & \\
\hline Village FE & Yes & Yes & Yes & Yes & Yes & Yes \\
\hline Control Y endline & 0.48 & 0.48 & 0.85 & 0.85 & 0.48 & 0.48 \\
\hline Control Y baseline & 0.34 & 0.34 & 0.87 & 0.87 & 0.52 & 0.52 \\
\hline R-sq. & 0.333 & 0.346 & 0.338 & 0.351 & 0.358 & 0.363 \\
\hline Observations & 812 & 812 & 846 & 846 & 834 & 834 \\
\hline
\end{tabular}

Standard errors in parentheses. " $p<0.10,{ }^{* *} p<0.05,{ }^{* * *} p<0.01$

103 Survey questions: (i) in col. 1-2, 'Based on your experience, how easy or difficult is it to do each of the following: To find out how the district government uses the revenues from people's taxes and fees?'; (ii) in col. 3-4, 'How much trust or mistrust do you have that the following groups/individuals act in the interest of ordinary people like you? The district government'; (iii) in col. 5-6, 'During the past 12 months, do you think the following actor's performance has got better, stayed the same, or got worse? The district government'. 
Table H4 DIALOGUE impact on perceptions of clan elders

\begin{tabular}{|l|c|c|c|c|c|c|}
\hline & $(\mathbf{1})$ & $\mathbf{( 2 )}$ & $\mathbf{( 3 )}$ & $\mathbf{( 4 )}$ & $\mathbf{( 5 )}$ & $\mathbf{( 6 )}$ \\
\hline & Transparency & Transparency & Trust & Trust & Performance & Performance \\
\hline Dialogue & 0.00 & 0.01 & 0.04 & 0.03 & 0.04 & 0.05 \\
\hline & $(0.06)$ & $(0.06)$ & $(0.05)$ & $(0.05)$ & $(0.06)$ & $(0.06)$ \\
\hline Baseline outcome & & & & & & No \\
\hline & No & Yes & No & Yes & Yes \\
\hline Controls & No & Yes & No & Yes & No & Yes \\
\hline & & & & & & \\
\hline Village FE & Yes & Yes & Yes & Yes & Yes & Yes \\
\hline Control Y endline & 0.51 & 0.51 & 0.87 & 0.87 & 0.44 & 0.44 \\
\hline Control Y baseline & 0.36 & 0.36 & 0.93 & 0.93 & 0.57 & 0.57 \\
\hline R-sq. & 0.304 & 0.312 & 0.287 & 0.302 & 0.340 & 0.348 \\
\hline Observations & 816 & 816 & 874 & 874 & 860 & 860 \\
\hline
\end{tabular}

Standard errors in parentheses. " $p<0.10,{ }^{* *} p<0.05,{ }^{* * *} p<0.01$

\section{Appendix I Informal tax payment and accountability actions}

Table I1 Contributors versus non-contributors to DIALOGUE programme in treatment communities
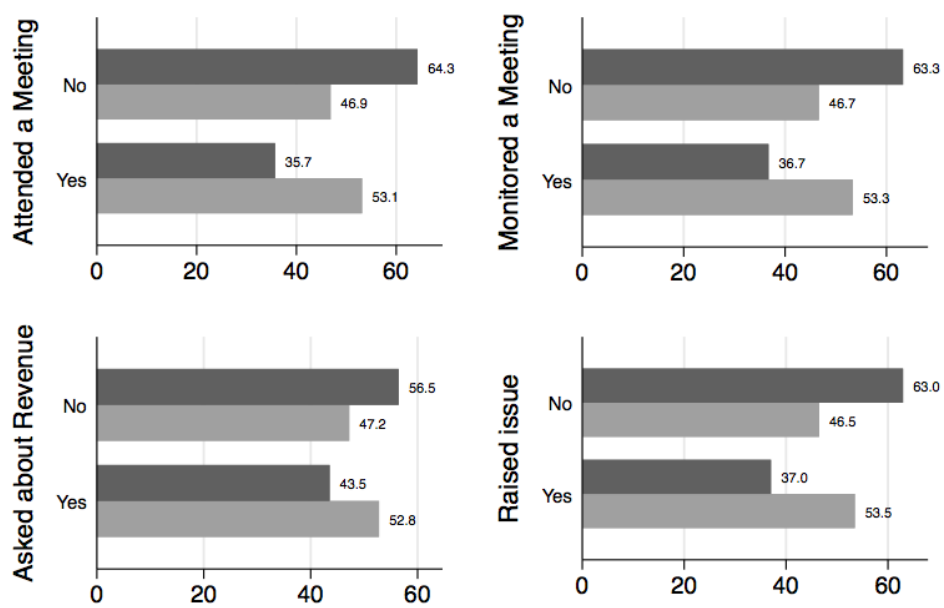

Non-contributors to Dialogue

Contributors to Dialogue 


\section{References}

3ie (2018) Does community-driven development build social cohesion or infrastructure?, Working Paper Brief, International Initiative for Impact Evaluation

Abdi, R. (2020, 20 March) Tweet by @RAbdiCG [Personal communication]

Abshir, S., Abdirahman, K. and Stogdon, H. (2020) Tax and the state in Somalia: Understanding domestic revenue mobilization, RVI Briefing Paper, RIft Valley Institute

Acemoglu, D., Cheema, A., Khwaja, A. and Robinson, J. (2020) 'Trust in State and Nonstate Actors: Evidence from Dispute Resolution in Pakistan', Journal of Political Economy 128(8): 3090-3147

ACLED (2020) Armed Conflict Location and Event Data Project (ACLED) dataset, https://www.acleddata.com/data/

Aga, D., Noorderhaven, N. and Vallejo, B. (2018) 'Project beneficiary participation and behavioural intentions promoting project sustainability: The mediating role of psychological ownership', Development Policy Review 36(5): 527-546, https://doi.org/10.1111/dpr.12241

Akramov, K. and Asante, F. (2008) Decentralization and Local Public Services in Ghana: Do Geography and Ethnic Diversity Matter?, GSSP Background Paper No. 16, International Food Policy Research Institute

Alatas, V., Banerjee, A., Hanna, R., Olken, B., Purnamasari, R. and Wai-Poi, M. (2019) 'Does Elite Capture Matter? Local Elites and Targeted Welfare Programs in Indonesia', AEA Papers and Proceedings 109: 334-339, https://doi.org/10.1257/pandp.20191047

Ali, M., Fjeldstad, O-H. and Sjursen, I. (2014) 'To Pay or Not to Pay? Citizens' Attitudes Toward Taxation in Kenya, Tanzania, Uganda, and South Africa', World Development 64: 828-842

Allen, S. and Gundel, J. (2017) Enhancing district-level governance and accountability in Somalia: A case study on the citizen-directed negotiated accountability project, KATUNI Consult

Angrist, J. and Pischke, J-S. (2009) Mostly Harmless Econometrics: An Empircist's Companion, Princeton University Press, https://press.princeton.edu/books/paperback/9780691120355/mostly-harmlesseconometrics

Arjona, A., Kasfir, N. and Mampilly, Z. (eds) (2015) Rebel Governance in Civil War, Cambridge University Press, https://doi.org/10.1017/CBO9781316182468

Armstrong, K. (2014) Community-Driven Recovery and Development (CDRD) Somalia Project-Phase III: Impact assessment and case study results: Districts of North Galkayo, South Galkayo, Abudwaq, Sheikh and Odweyne, Danish Refugee Council

Bak, A. (2019) When the fiscal social contract is not about tax: Understanding the limited role of taxation in social accountability in Senegal, PhD dissertation, Forlaget Politica 
Baker, R., Walker, J. and Williams, A. (2009) 'Matching contributions and the voluntary provision of a pure public good: Experimental evidence', Journal of Economic Behavior and Organization 70(1-2): 122-134, https://doi.org/10.1016/j.jebo.2008.12.005

Bakonyi, J., Cohen, G. and Bedard, P-O. (2015) An evaluation of Hogaan iyo Nabad: A community driven governance programme in Somalia/Somaliland, Durham University

Balán, P., Bergeron, A., Tourek, G. and Weigel, J. (2020) Local elites as state capacity: How city chiefs use local information to increase tax compliance in the D.R. Congo, CEPR Discussion Paper No. DP15138, Centre for Economic Policy Research

Baldwin, K. (2019) 'Elected MPs, Traditional Chiefs, and Local Public Goods: Evidence on the Role of Leaders in Co-Production From Rural Zambia', Comparative Political Studies 52(12): 1925-1956, https://doi.org/10.1177/0010414018774372

- (2015) The paradox of traditional chiefs in democratic Africa, Cambridge University Press

(2013) Why Vote with the Chief? Political Connections and Public Goods Provision in Zambia, American Journal of Political Science 57(4): 794-809

and Holzinger, K. (2019) 'Traditional political institutions and democracy: Reassessing their compatibility and accountability', Comparative Political Studies 52(12): 17471774

and Winters, M. (2020) How Do Different Forms of Foreign Aid Affect Government Legitimacy? Evidence from an Informational Experiment in Uganda, Studies in Comparative International Development 55(2): 160-183, https://doi.org/10.1007/s12116-020-09303-8

(2018) Bypass aid and perceptions of local government performance and legitimacy, AidData Working Paper No. 56, AidData

Bandula-Irwin, T. (2021) Sool DIALOGUE project: Endline research report, Danish Refugee Council

Basurto, M., Dupas, P. and Robinson, J. (2020) Decentralization and efficiency of subsidy targeting: Evidence from chiefs in rural Malawi, Journal of Public Economics 185, https://doi.org/10.1016/j.jpubeco.2019.07.006

Baynes, K. (2001) 'Legitimacy', in J. Krieger (ed), The Oxford Companion to Politics of the World (2nd ed.), Oxford University Press

Beetham, D. (1991) The Legitimation of Power, Palgrave MacMillan

Blair, R. and Winters, M. (2020) 'Foreign Aid and State-Society Relations: Theory, Evidence, and New Directions for Research', Studies in Comparative International Development, 55(2): 123-142, https://doi.org/10.1007/s12116-020-09301-w

Bodea, C. and LeBas, A. (2016) 'The Origins of Voluntary Compliance: Attitudes toward Taxation in Urban Nigeria', British Journal of Political Science 46(1): 215-238, https://doi.org/10.1017/S000712341400026X 
Boesten, J., Mdee, A. and Cleaver, F. (2011) 'Service delivery on the cheap? Communitybased workers in development interventions', Development in Practice 21(1): 41-58

Bowles, S. and Gintis, H. (2004) 'Persistent parochialism: Trust and exclusion in ethnic networks', Journal of Economic Behavior and Organization 55(1): 1-23, https://doi.org/10.1016/j.jebo.2003.06.005

Braithwaite, V. and Levi, M. (1998) Trust and Governance, Russell Sage Foundation

Brett, E. (2003) 'Participation and accountability in development management', The Journal of Development Studies 40(2): 1-29, https://doi.org/10.1080/00220380412331293747

Bryld, E. and Kamau, C. (2013) Community-Driven Recovery and Development Project: Political Economy Analysis in Dollow, Danish Refugee Council and Tana

and Sinigallia (2013) Gatekeepers in Mogadishu, The Somalia Cash Consortium, https://www.calpnetwork.org/wp-content/uploads/2020/01/1376766704.pdf

Cammett, M. and MacLean, L. (2014) The politics of non-state social welfare, Cornell University Press

Carrick-Hagenbarth, J. (2016) Elite capture, free riding, and project design: A case study of a community-driven development project in Ceara, Brazil, Doctoral Dissertation, University of Massachusetts

Carvalho, S. and White, H. (2004) 'Theory-Based Evaluation: The Case of Social Funds', American Journal of Evaluation 25(2): 141-160

Casey, K. (2018) 'Radical decentralization: Does community-driven development work?', Annual Review of Economics 10: 139-163, https://doi.org/10.1146/annureveconomics- 080217-053339

_ Glennerster, R. and Miguel, E. (2013) The GoBifo project evaluation report: Assessing the impacts of community-driven development in Sierra Leone, International Initiative for Impact Evaluation

— - (2011) Reshaping Institutions: Evidence on Aid Impacts using a pre-analysis plan, IGC Working Paper S-1002-SLE-1, International Growth Centre

Catterson, J. and Lindahl, C. (1998) The sustainability enigma: Aid dependency and phasing out of projects, the case of Swedish aid to Tanzania, Management Perspective International for SIDA

Centeno, M., Kohli, A. and Yashar, D. (2017) 'Unpacking states in the developing world', in M. Centeno, A. Kohli, and D. Yashar (eds), States in the developing world, Cambridge University Press

Chandler, D. (2007) 'The state-building dilemma: Good governance or democratic government', in A. Hehir and N. Robinson (eds) State-building: Theory and practice, Routledge

Chase, R. (2002) 'Supporting Communities in Transition: The Impact of the Armenian Social Investment Fund', The World Bank Economic Review 16(2): 219-240 
Chlouba, V. (2020) 'Traditional Authority and State Legitimacy: Evidence From Namibia', The Journal of the Middle East and Africa 11(3): 251-272, https://doi.org/10.1080/21520844.2020.1791558

Ciorciari, J. and Krasner, S. (2018) 'Contracting out, legitimacy, and state building', Journal of Intervention and Statebuilding 12(4): 484-505

Cleaver, F., Franks, T., Maganga, F. and Hall, K. (2013) 'Institutions, Security, and Pastoralism: Exploring the Limits of Hybridity', African Studies Review 56(3): 165-189

Cramer, C. (2006) Civil war is not a stupid thing, Hurst

Crouch, J. and Chevreau, O. (2016) Forging Jubaland: Community perspectives on federalism, governance and reconciliation, Saferworld

Cruz, C. and Schneider, C. (2017) 'Foreign Aid and Undeserved Credit Claiming', American Journal of Political Science 61(2): 396-408, https://doi.org/10.1111/ajps.12285

D'Arcy, M. (2011) Why Do Citizens Assent to Pay Tax? Legitimacy, Taxation and the African State, Afrobarometer Working Paper No. 126, Afrobarometer

De Herdt, T. and Olivier de Sardan, J.-P. (eds) (2015) Real governance and pratical norms in Sub-Saharan Africa: The game of the rules, Routledge

_ and Titeca, K. (2019) Negotiating Public Services in the Congo: State, Society and Governance, Zed Books

de Waal, A. (2017) Somalia synthesis paper, 2017, CRP Working Paper, Conflict Research Programme, http://eprints.Ise.ac.uk/100162/4/De_Waal_somalia_synthesis_paper_published.pdf

Dias, P. (2011) The CDRD project, Beletweyne: An assessment of the degree to which recommendations from a 2010 stakeholder analysis were implemented, Danish Refugee Council

Dietrich, S., Mahmud, M. and Winters, M. (2018) 'Foreign Aid, Foreign Policy, and Domestic Government Legitimacy: Experimental Evidence from Bangladesh', Journal of Politics 80(1): 133-148

_ and Winters, M. (2015) 'Foreign Aid and Government Legitimacy', Journal of Experimental Political Science 2: 164-171

Dongier, P., Van Domelen, J., Ostrom, E., Rizvi, A., Wakeman, W., Bebbington, A., Alkire, S., Esmail, T. and Polski, M. (2002) 'Community-Driven Development', in J. Klugman (ed), A Sourcebook for Poverty Reduction Strategies: Vol. 1: Core techniques and cross-cutting issues, World Bank

DRC (2014) Impact Assessment and Case Study Results: Community-Driven Recovery and Development (CDRD) Somalia Project, Phase III, Danish Refugee Council

and Justice Studio (2015) Community-Driven Recovery and Development (CDRD) and Develop Informed and Accountable Local Governance through User Empowerment (DIALOGUE) Project Evaluation, Danish Refugee Council and Justice Studio 
and Shaqodoon (2017) Proposal to SSF for the DIALOGUE project in Gedo region, Danish Refugee Council and Shaqodoon

Dreier, S. and Lake, M. (2019) 'Institutional legitimacy in Sub-Saharan Africa', Democratization, 26(7): 1194-1215, https://doi.org/10.1080/13510347.2019.1613377

Eckel, C. and Grossman, P. (2003) 'Rebate versus matching: Does how we subsidize charitable contributions matter?', Journal of Public Economics 87(3-4): 681-701, https://doi.org/10.1016/S0047-2727(01)00094-9

Edwards, M. and Hulme, D. (1996) 'Too close for comfort? The impact of official aid on NGOs', World Development 24: 96-973

Englebert, P. (2002) State legitimacy and development in Africa, Lynne Rienner

Ensminger, J. (2017) Corruption in community-driven development: A Kenyan case study with insights from Indonesia, U4 Issue 2017:9, Chr. Michelsen Institute

Eubank, N. (2012) 'Taxation, Political Accountability and Foreign Aid: Lessons from Somaliland', The Journal of Development Studies 48(4): 465-480

Evans, M., Harkness, S. and Salomon, H. (2020) Informal taxes and transfers in subSaharan Africa, ODI Working Paper No. 598, Overseas Development Institute

Farrell, H. (2009) The Political Economy of Trust: Institutions, Interests and Inter-Firm Cooperation in Italy and Germany, Cambridge University Press

Fearon, J., Humphreys, M. and Weinstein, J. (2009) 'Can development aid contribute to social cohesion after civil war? Evidence from a field experiment in post-conflict Liberia', American Economic Review: Papers and Proceedings 99(2): 287-291

Fehr, E. and Gächter, S. (2000) 'Fairness and Retaliation: The Economics of Reciprocity', Journal of Economic Perspectives 14(3): 159-81

Fine, B. (2015) Theories of Social Capital: Researchers Behaving Badly, Pluto Press, https://doi.org/10.2307/j.ctt183pdrp

Fisk, K. and Cherney, A. (2017) 'Pathways to Institutional Legitimacy in Postconflict Societies: Perceptions of Process and Performance in Nepal', Governance 30(2): 263-281, https://doi.org/10.1111/gove.12208

Fjeldstad, O-H. (2001) 'Taxation, Coercion and Donors: Local Government Tax Enforcement in Tanzania', Journal of Modern African Studies 39(2): 289-306

Fox, J. (2007) 'The uncertain relationship between transparency and accountability', Development in Practice 17(4-5): 663-671, https://doi.org/10.1080/09614520701469955

FRS (2013) The Somali Compact, Federal Republic of Somalia, https://reliefweb.int/sites/reliefweb.int/files/resources/20130916_communique.pdf

Fukuyama, F. (2013) 'What is Governance?', Governance: An International Journal of Policy, Administration, and Institutions 26(3): 347-368

— (1995) Trust: The social virtues and the creation of prosperity, Free Press 
Gadenne, L. (2017) 'Tax Me, But Spend Wisely: The Political Economy of Taxes, Evidence from Brazilian Local Governments', American Economic Journal: Applied Economics 9(1): 274-314

Gallien, M. (2021) 'Researching the Politics of Illegal Activities', PS: Political Science and Politics 1-5, https://doi.org/10.1017/S1049096521000317

Ganev, V. (2007) Preying on the state: The transformation of Bulgaria after 1989, Cornell University Press

Getu, M. and Devereux, S. (2013) Informal and Formal Social Protection Systems in SubSaharan Africa, African Books Collective

Guerrero, A. (2011) Rebuilding Trust in Government via Service Delivery: The Case of Medellin, Colombia, World Bank

Gundel, J. (2006) The predicament of the "Oday": The role of traditional structures in security, rights, law and development in Somalia, Danish Refugee Council and Novib/Oxfam,

https://logcluster.org/sites/default/files/documents/Gundel_The\%2520role\%2520of\%2 520traditional\%2520structures.pdf

Hagmann, T. (2016) Stabilization, extraversion and political settlements in Somalia, Rift Valley Institute

and Hoehne, M. (2009) 'Failures of the state failure debate: Evidence from the Somali territories', Journal of International Development 21: 42-57

Hamming, T. (2011) 'Stabilizing Somalia through integrating community-driven safety with socio-economic development', Community Development Journal 46(4): 579-584

Hammond, L., Awad, M., Dagane, A. I., Hansen, P., Horst, C., Menkhaus, K. and Obare, L. (2011) Cash and Compassion: The role of the Somali diaspora in relief, development and peace-building, (Volume I), UNDP

Handley, A. (2020) Business and social crisis in Africa, Cambridge University Press

Hart, K. (2005) Formal Bureaucracy and the Emergent Forms of the Informal Economy, UNU-WIDER Research Paper No 2005/11, UNU-WIDER

Hartkorn, S. (2011) Community-led stabilisation in Somalia, No. FMR37, Danish Demining Group

Hearn, S. and Zimmerman, T. (2014) A New Deal for Somalia? : The Somali Compact and its Implications for Peacebuilding, New York University Center on International Cooperation.

Hedlund, K., Majid, N., Maxwell, D. and Nicholson, N. (2013) Final evaluation of the unconditional cash and voucher response to the 2011-12 crisis in Southern and Central Somalia, UNICEF, https://www.unicef.org/evaldatabase/files/Somalia_2013002_Humanitarian_Outcomes_Somalia_Cash_and_Voucher_Evaluation_Full_Report .pdf

Helmke, G. and Levitsky, S. (2004) 'Informal Institutions and Comparative Politics: A Research Agenda', Perspectives on Politics 2(4): 725-740 
Henn, S. (2018) Complements or substitutes: How institutional choices shape the interaction between traditional leaders and the state in Africa, Working Paper, http://soerenhenn.com/files/Henn_JMP.pdf

Hertog, S. (2010) Princes, brokers, and bureaucrats: Oil and the state in Saudi Arabia, Cornell University Press

Hickey, S. (2012) 'Beyond "poverty reduction through good governance": The new political economy of development in Africa', New Political Economy 17(5): 683-690

Hill, M. (2010) No redress: Somalia's forgotten minorities, Minority Rights Group International

Hinds, R. (2013) Somali networks: Structures of clan and society, GSDRC Helpdesk Research Report 949, GSDRC, University of Birmingham

Hiraal Institute (2020) Semi-annual Somalia Security Report, Hiraal Institute

Hoehne, M. (2011) No easy way out: Traditional authorities in Somaliland and the limits of hybrid political orders, DIIS Working Paper 2011:18, Danish Institute for International Studies

_ (2010) 'Political representation in Somalia: Citizenship, clanism, and territoriality', in Conciliation Resources, Whose peace it is anyway? Connecting Somali and international peacemaking

Holzinger, K., Kern, F. and Kromrey, D. (2016) 'The Dualism of Contemporary Traditional Governance and the State: Institutional Setups and Political Consequences', Political Research Quarterly 69(3): 469-481, https://doi.org/10.1177/1065912916648013

Holzner, C. (2010) Poverty of democracy: The institutional roots of political participation in Mexico, University of Pittsburgh Press

Hudson, V. Bowen, D. and Nielsen, P. (2015) 'Clan governance and state stability: The relationship between female subordination and political order', American Political Science Review 109(3): 535-555

Humphreys, M., Sanchez de la Sierra, R. and van der Windt, P. (2012) Social and economic impacts of Tuungane: Final report on the effects of a community driven reconstruction program in Eastern Democratic Republic of Congo

Huq, L. (2020) 'Does community-driven development (CDD) empower the powerless: The case of urban Bangladesh' in Theorizing Cohesive Development: An Alternative Paradigm, Routledge

Hussein, S. (2018) The impact of the role of traditional leaders on politico-governance in Somalia: Present realities and past reflections, Somali Institute for Development Research and Analysis (SIDRA), https://www.africaportal.org/publications/impactrole-traditional-leaders-politico-governance-somalia-present-realities-and-pastreflections/

ICG (2020) Ending the dangerous standoff in southern Somalia, Africa Briefing No. 158, International Crisis Group 
(2013, 21 May) 'Jubaland in Jeopardy: The Uneasy Path to Statebuilding in Somalia', ICG Commentary, https://www.crisisgroup.org/africa/horn-africa/somalia/jubalandjeopardy-uneasy-path-state-building-somalia

IMF (2017) Second and final review under the staff-monitored program and request for a new staff-monitored program, IMF Country Report No. 17/204, International Monetary Fund

Ingiriis, M. (2018) 'From pre-colonial past to the post-colonial present: The contemporary clan-based configurations of statebuilding in Somalia', African Studies Review 61(2): 55-77

- (2015) 'Politics as a profitable business: Patronage, patrimony, predatation, and primordial power in contemporary Somalia', Journal of Somali Studies 2(1-2): 67-97, https://doi.org/10.10520/EJC181269

Isham, J. and Kähkönen, S. (2002) 'Institutional Determinants of the Impact of CommunityBased Water Services: Evidence from Sri Lanka and India', Economic Development and Cultural Change 50(3): 667-691, https://doi.org/10.1086/342357

Jimenez, E. and Paqueo, V. (1996) 'Do local contributions affect the efficiency of public primary schools?', Economics of Education Review 15(4): 377-386, https://doi.org/10.1016/S0272-7757(96)00029-5

Jordan, K. (2016) Community-based and customary taxation in south-central Somalia: Possibilities for hybrid governance and DIALOGUE programming, Danish Refugee Council, Somalia

Juul, K. (2006) 'Decentralization, Local Taxation and Citizenship in Senegal', Development and Change 37(4): 821-846

Karim, S. (2020) 'Relational State Building in Areas of Limited Statehood: Experimental Evidence on the Attitudes of the Police', American Political Science Review 114(2): 536-551, https://doi.org/10.1017/S0003055419000716

Karlan, D. and List, J. (2021) Does Price Matter in Charitable Giving? Evidence from a Large-Scale Natural Field Experiment

Kim, J., Sheely, R. and Schmidt, C. (2020) Social capital and social cohesion measurement toolkit for community-driven development operations, Mercy Ciros and The World Bank

Kleemeier, E. (2000) 'The Impact of Participation on Sustainability: An Analysis of the Malawi Rural Piped Scheme Program', World Development 28(5): 929-944, https://doi.org/10.1016/S0305-750X(99)00155-2

Kumar, S. and Corbridge, S. (2002) 'Programmed to Fail? Development Projects and the Politics of Participation', Journal of Development Studies 39(2): 73-103, https://doi.org/10.1080/00220380412331322761

Levi, M. (1988) Of Rule and Revenue, University of California Press

and Sacks, A. (2009) 'Legitimating beliefs: Sources and indicators', Regulation and Governance 3(4): 311-333 
and Tyler, T. (2009) 'Conceptualizing Legitimacy, Measuring Legitimating Beliefs', American Behavioral Scientist 53(3): 354-375

Lewis, I. (1988) A modern history of Somalia: Nation and state in the Horn of Africa, 3rd ed., Westview Press

Lieberman, E. (2002) 'Taxation Data as Indicators of State-Society Relations: Possibilities and Pitfalls in Cross-National Research', Studies in Comparative International Development 36(4): 89-115

Logan, C. (2009) 'Selected chiefs, elected councilors and hybrid democrats: Popular perspectives on the co-existence of democracy and traditional authority', The Journal of Modern African Studies 47: 101-128

Lund, C. (2006) 'Twilight Institutions: Public Authority and Local Politics in Africa', Development and Change 37(4): 685-705

Majid, N. and McDowell, S. (2012) 'Hidden dimensions of the Somalia famine', Global Food Security 1(1): $36-42$

Mansuri, G. and Rao, V. (2004) 'Community-based and -driven development: A critical review', The World Bank Research Observer 19(1): 1-39

Martin, L. (2016) Tax, loss aversion, and accountability: Theory and Experimental Evidence for Taxation's Effect on Citizen Behavior, Working paper, https://docs.google.com/viewer?a=v\&pid=sites\&srcid=ZGVmYXVsdGRvbWFpbnxsd WN5bWFydGlufGd4OjFkMzImNGE0MGNhMTc3Mg

Mathie, A. and Cunningham, G. (2003) 'From clients to citizens: Asset-based Community Development as a strategy for community-driven development', Development in Practice 13(5): 474-486, https://doi.org/10.1080/0961452032000125857

Matthews, J. (1997) 'Power shift', Foreign Affairs 76: 50-66

Maxwell, D. and Majid, N. (2016) Famine in Somalia: Competing Imperatives, Collective Failures, 2011-12, Oxford University Press, https://oxford.universitypressscholarship.com/view/10.1093/acprof:oso/97801904993 89.001.0001/acprof-9780190499389

McCarthy, G. (2019) 'Democratic Deservingness and Self-Reliance in Contemporary Myanmar', Sojourn: Journal of Social Issues in Southeast Asia 34(2): 327-365

(2018) Regressive democracy: Explaining distributive politics in Myanmar's political transition, PhD thesis, The Australian National University

(2016) Building on What's There: Insights on social protection and public goods provision from central-east Myanmar, IGC Working Paper S-53308-MYA-2, International Growth Centre

and Farrelly, N. (2020) 'Peri-conflict peace: Brokerage, development and illiberal ceasefires in Myanmar's borderlands', Conflict, Security and Development 20(1): 141163, https://doi.org/10.1080/14678802.2019.1705072

Steenbergen, D., Warren, C., Acciaioli, G., Baker, G., Lucas, A. and Rambe, V. (2016) 'Community driven development and structural disadvantage: Interrogating the social 
turn in development programming in Indonesia', The Journal of Development Studies 53(12): 1988-2004

McKenzie, D. (2012) 'Beyond baseline and follow-up: The case for more T in experiments', Journal of Development Economics 99(2): 210-221, https://doi.org/10.1016/j.jdeveco.2012.01.002

McLoughlin, C. (2015) 'When does service delivery improve the legitimacy of a fragile or conflict-affected state?', Governance: An International Journal of Policy, Administration, and Institutions 28(3): 341-356

Meagher, K. (2012) 'The strength of weak states? Non-state security forces and hybrid governance in Africa', Development and Change 43(5): 1073-1101

_ (2005) 'Social capital or analytical liability? Social networks and African informal economies', Global Networks 5(3): 217-238

— (1990) The Hidden Economy: Informal and Parallel Trade in Northwestern Uganda, Review of African Political Economy 47: 64-83

— De Herdt, T. and Titeca, K. (2014) Unravelling public authority: Paths of hybrid governance in Africa, 10 Research Brief, London School of Economics

Meier, S. (2007) 'Do Subsidies Increase Charitable Giving in the Long Run? Matching Donations in a Field Experiment', Journal of the European Economic Association 5(6): 1203-1222, https://doi.org/10.1162/JEEA.2007.5.6.1203

Menkhaus, K. (2014a) Aid and institution-building in fragile states: The case of Somaliinhabited eastern Horn of Africa, WIDER Working Paper No. 2014/002, UNU-WIDER

(2014b) 'State collapse and local response in Somalia', in Trauschweizer, Ingo and S. Miner (eds), Failed States and Fragile Societies: A new world disorder?, Ohio University Press

- (2014c) 'State failure, state-building, and prospects for a "Functional Failed State" in Somalia', The ANNALS of the American Academy of Political and Social Science 656(1): 154-172

— (2012) After the Kenyan Intervention in Somalia, Enough Project

- (2011) Somalia and the Horn of Africa, World Development Report 2011 Background Case Study No. 63204, World Bank, https://doi.org/10.1596/27342

_ (2007) 'The Crisis in Somalia: Tragedy in Five Acts', African Affairs 106(424): 357-390, JSTOR

(2006) 'Governance without Government in Somalia: Spoilers, State Building, and the Politics of Coping', International Security 31(3): 74-106, http://www.mitpressjournals.org/doi/pdf/10.1162/isec.2007.31.3.74

_ (1998) 'Somalia: Political Order in a Stateless Society', Current History 97(619): 220

Migdal, J. (1994) 'The State in Society: An Approach to Struggles for Domination', in J. Migdal, A. Kohli, and V. Shue (eds), State power and social forces: Domination and transformation in the Third World, Cambridge University Press 
Miguel, E. and Gugerty, M. (2005) 'Ethnic Diversity, Social Sanctions and Public Goods in Kenya', Journal of Public Economics 89: 2325-2368

Milner, H., Nielson, D. and Findley, M. (2016) 'Citizen preferences and public goods: Comparing preferences for foreign aid and government programs in Uganda', The Review of International Organizations 11(2): 219-245, https://doi.org/10.1007/s11558016-9243-2

Montinola, G., Taylor, T. and Largoza, G. (2020) 'Foreign aid, government spending, and contributions toward public goods: Experimental evidence from the Philippines', Studies in Comparative International Development 55: 201-227

Moore, M. (2004) 'Revenues, State Formation and the Quality of Governance in Developing Countries', International Political Science Review 25(3): 297-319

_ (1998) 'Death Without Taxes: Democracy, State Capacity and Aid Dependence in the Fourth World', in M. Robinson and G. White (eds), The Democratic Development State: Politics and Institutional Reform, Oxford University Press

Moskowitz, K. (2017) 'Sweating to Help Themselves: Self-Help and the Contradictions of Citizenship and Development in Decolonizing Kenya', International Journal of African Historical Studies 50(1): 35-58

Mosley, J. (2015) Somalia's federal future: Layered agendas, risks and opportunities, Chatham House Research Paper, Chatham House, https://www.chathamhouse.org/sites/default/files/field/field_document/20150902Soma liaFederalFutureMosley.pdf

Moss, T., Pettersson, G. and van de Walle, N. (2006) An Aid-Institutions Paradox? A Review Essay on Aid Dependency and State Building in Sub-Saharan Africa, Center for Global Development Working Paper Number 74, Center for Global Development

Mosse, D. (2005) Cultivating Development: An Ethnography of Aid Policy and Practice, Pluto Press

Musau, S. (2013) 'Clans' and Clannism's Control over Weak Political Institutions', ITPCM International Commentary 9 (34)

Mvukiyehe, E. and van der Windt, P. (2020) Assessing the longer term impact of communitydriven development programs: Evidence from a field experiment in the Democratic Republic of Congo, Policy Research Working Papers, The World Bank

Mwangi, O. (2016) 'Jubaland: Somalia's new security dilemma and state-building efforts', Africa Review 8(2): 120-132, https://doi.org/10.1080/09744053.2016.1186867

Nkonya, E., Phillip, D., Mogues, T., Pender, J., Yahaya, M. K., Adebowale, G. and Arokoyo, T. (2008) Impacts of a Pro-Poor Community-Driven Development Project in Nigeria, IFPRI Discussion Paper No. 00756, International Food Policy Research Institute

Nunn, N. (2008) 'The Long-term Effects of Africa's Slave Trades', The Quarterly Journal of Economics 123(1): 139-176

Nussbaum, M. and Sen, A. (eds) (1993) The Quality of Life, Oxford University Press, https://doi.org/10.1093/0198287976.001.0001 
Obiyan, A. (2005) 'A critical examination of the state versus non-governmental organizations (NGOs) in the policy sphere in the global south: Will the state die as NGOs thrive in Sub-Saharan Africa and Asia?', African and Asian Studies 4(3): 301-327

OECD (2011) Supporting statebuilding in situations of conflict and fragility: Police guidance, DAC, OECD

(2008) Reaching our development goals: Why does aid effectiveness matter?, OECD Development Co-Operation Directorate

Olken, B. and Singhal, M. (2011) 'Informal Taxation', American Economic Journal: Applied Economics 3: 1-28

Ostrom, E. (1994)'Constituting Social Capital and Collective Action', Journal of Theoretical Politics 6(4): 527-562, https://doi.org/10.1177/0951692894006004006

Paler, L., Prichard, W., Sanchez de la Sierra, R. and Samii, C. (2017) Survey on total tax burden in the DRC, Department for International Development

Parker, A. and Serrano, R. (2000) Promoting Good Local Governance through Social Funds and Decentralization, World Bank

Pavanello, S., Watson, C., Onyango-Ouma, W. and Bukuluki, P. (2016) 'Effects of cash transfers on community interactions: Emerging evidence', The Journal of Development Studies 52(8): 1147-1161

Peters, B. (2014) 'Is governance for everybody?', Policy and Society 33(4): 301-306

Peters, J., Langbein, J. and Roberts, G. (2018) 'Generalization in the Tropics - Development Policy, Randomized Controlled Trials, and External Validity', The World Bank Research Observer 33(1): 34-64, https://doi.org/10.1093/wbro/lkx005

Prichard, W. (forthcoming) Rethinking tax morale: What is it? How to measure it? Why is it important?, ICTD Working Paper, Brighton: Institute of Development Studies

— (2015) Taxation, Responsiveness and Accountability in Sub-Saharan Africa: The Dynamics of Tax Bargaining, Cambridge University Press

— Brun, J.-F. and Morrisey, O. (2012) Donors, Aid and Taxation in Developing Countries: An Overview, ICTD Working Paper, Brighton: Institute of Development Studies

Raballand, G. and Knebelmann, J. (2020) Domestic resource mobilization in Somalia, World Bank,

http://documents1.worldbank.org/curated/en/644541596773094934/pdf/DomesticResource-Mobilization-in-Somalia.pdf

Radnitz, S. (2011) 'Review: Informal politics and the state', Comparative Politics 43(3): 351 371

Ramalingam, B., Laric, M. and Primrose, J. (2014) From best practice to best fit: Understanding and navigating wicked problems in international development, Working Paper, Overseas Development Institute 
Ranganathan, M. (2014) 'Paying for Pipes, Claiming Citizenship: Political Agency and Water Reforms at the Urban Periphery: Political agency and water reforms in Bangalore', International Journal of Urban and Regional Research 38(2): 590-608, https://doi.org/10.1111/1468-2427.12028

Rawlings, L., Sherburne-Benz, L. D. and VanDomelen, J. (2004) Evaluating social funds: A cross-country analysis of community investments. World Bank.

Renders, M. and Terlinden, U. (2010) 'Negotiating Statehood in a Hybrid Political Order: The Case of Somaliland', Development and Change 41(4): 723-746

Rift Valley Institute (2017) Forging Jubaland: Community perspectives on federalism, governance and reconciliation, Rlft Valley Institute, https://www.refworld.org/pdfid/58c6bf654.pdf

Risse, T. (2011) Governance without a state? Policies and politics in areas of limited statehood, Columbia University Press

and Stollenwerk, E. (2018) 'Legitimacy in Areas of Limited Statehood', Annual Review of Political Science 21(1): 403-418, https://doi.org/10.1146/annurev-polisci-041916023610

Robinson, M. (2008) 'Hybrid states: Globalisation and the politics of state capacity', Political Studies 56(3): 566-583

Roitman, J. (2005) Fiscal disobedience: An anthropology of economic regulation in Central Africa, Princeton University Press

(1990) 'The Politics of the Informal Markets in Sub-Saharan Africa', Journal of Modern African Studies 28(4): 671-696

Rondeau, D. and List, J. (2008) 'Matching and challenge gifts to charity: Evidence from laboratory and natural field experiments', Experimental Economics 11(3): 253267, https://doi.org/10.1007/s10683-007-9190-0

Sacks, A. (2012) Can Donors and Non-State Actors Undermine Citizens' Legitimating Beliefs, No. 6158 Policy Research Working Paper, World Bank

and Larizza, M. (2012) Why Quality Matters: Rebuilding Trustworthy Local Government in Post-Conflict Sierra Leone, Policy Research Working Paper No. 6021, World Bank, https://doi.org/10.1596/1813-9450-6021

Saggiomo, V. (2011) 'From Charity to Governance: Islamic NGOs and Education in Somalia', The Open Area Studies Journal 4(1): 53-61, https://doi.org/10.2174/1874914301104010053

Saguin, K. (2018) 'Why the poor do not benefit from community-driven development: Lessons from particpatory budgeting', World Development 112: 220-232

Samuels, F., Jones, N. and Malachowska, A. (2013) Holding cash transfers to account: Beneficiary and community perspectives, Overseas Development Institute

Schaar, J. (1984) 'Legitimacy in the modern state, in W. Connolly (ed), Legitimacy and the State, Basil Blackwell 
Schäferhoff, M. (2014) 'External Actors and the Provision of Public Health Services in Somalia', Governance 27(4): 675-695, https://doi.org/10.1111/gove.12071

Schedler, A. (1999) 'Conceptualizing Accountability' in A. Schedler, L. Diamond and M. Plattner (eds), The Self-Restraining State: Power and Accountability in New Democracies, Lynne Rienner Publishers

Schmelzle, C. and Stollenwerk, E. (2018) 'Virtuous or vicious circle? Governance effectiveness and legitimacy in areas of limited statehood', Journal of Intervention and Statebuilding 12(4): 449-467

Shah, A. (2014, 11 December) Principles and the practice of fiscal equalization transfers with special emphasis on solidarity or Robin Hood programs, The Ministry of Finance , Poland and the World Bank Workshop on 'Fiscal Equalization Transfers International Practices : Lessons for Poland'

- (2010) Sponsoring A Race To The Top: The Case For Results-Based Intergovernmental Finance For Merit Goods, The World Bank, https://doi.org/10.1596/1813-9450-5172

Smart Vision (2019) Report of the final evaluation of DIALOGUE project DRC Somalia country programme, Smart Vision for Consultancy and Development

Ssereo, F. (2003) 'Clan politics, clan-democracy, and conflict regulation in Africa: The experience of Somalia', The Global Review of Ethnopolitics 2(3-4): 25-40

SSF (2019, 22 May) The Dialogue Project: Building Peace and increasing citizen government trust - Somalia Stability Fund, Somalia Stability Fund, http://stabilityfund.so/2019/05/22/the-dialogue-project-building-peace-and-increasingcitizen-government-trust/

Stel, N. (2017) 'Mediated stateness as a continuum: Exploring the changing governance relations between the PLO and the Lebanese state', Civil Wars 19(3): 348-376

Stollenwerk, E. (2018) 'Securing Legitimacy? Perceptions of Security and ISAF's Legitimacy in Northeast Afghanistan', Journal of Intervention and Statebuilding 12(4): 506-526, https://doi.org/10.1080/17502977.2018.1504855

Strand, A., Toje, H., Jerve, A. M. and Samset, I. (2003) Community-driven development in contexts of conflict, CMI Report No. 11, Chr. Michelsen Institute

Stremlau, N. (2016) 'Constitution-making, media, and the politics of participation in Somalia', African Affairs 115: 225-245

Sun, Y., Asante, F. and Birner, R. (2010) Opportunities and Challenges of Community-Based Rural Drinking Water Supplies, IFPRI Discussion Paper No. 01026, International Food Policy Research Institute

Tendler, J. (2000) 'Why are social funds so popular?', in S. Yusuf, W. Wu and S. J. Evenett (eds), Local dynamics in an era of globalization: 21st century catalysts for development, Oxford University Press

and Serrano, R. (1999) The Rise of Social Funds: What Are They A Model Of?, UNDP 
Tiebout, C. (1956) 'A pure theory of local expenditures', Journal of Political Economy 64(5): 415-424

Titeca, K. (2012) 'Tycoons and Contraband: Informal Cross-Border Trade in North-Western Uganda', Journal of Eastern African Studies 6(1): 47-63

and De Herdt, T. (2011) 'Real Governance Beyond the "Failed State": Negotiating Education in the Democratic Republic of the Congo', African Affairs 110(439): 213231

and Flynn, R. (2014) '"Hybrid Governance," Legitimacy, and (II)legality in the Informal Cross-Border Trade in Panyimur, Northwest Uganda', African Studies Review 57(1): 71-91

Torpey-Saboe, N. (2015) 'Does NGO presence decrease government spending? A look at municipal spending on social services in Brazil', World Development 74: 479-488

Tsai, L. (2011) 'Friends or Foes? Nonstate Public Goods Providers and Local State Authorities in Nondemocratic and Transitional Systems', Studies in Comparative International Development 46: 46-69

- (2007) Accountability without democracy: How solidarity groups provide public goods in rural China, Cambridge University Press

UN Habitat (2018) Land and conflict in Jubaland: Root cause analysis and recommendations, UN Habitat

UNFPA (2014) Population estimation survey 2014 for the 18 pre-war regions of Somalia, UNFPA, http://www.dns.org.so/docs/PESS_Somal_population.pdf

UNOSOM (2014) United Nations Somalia Integrated Strategic Framework: 2014-2016, United Nations Assistance Mission in Somalia, https://unsom.unmissions.org/sites/default/files/old_dnn/docs/Somalia\%20ISF\%2020 14-2016\%20FINAL\%20signed.pdf

UNSC (2018) Letter dated 2 October 2018 from the Monitoring Group on Somalia and Eritrea addressed to the Chair of the Security Council Committee pursuant to resolutions 751 (1992) and 1907 (2009) concerning Somalia and Eritrea (S/2018/1002), United Nations Security Council

Usmani, F., Jeuland, M. and Pattanayak, S. (2018) NGOs and the effectiveness of interventions, WIDER Working Paper No. 59, UNU-WIDER

Vajja, A. and White, H. (2008) 'Can the World Bank Build Social Capital? The Experience of Social Funds in Malawi and Zambia', The Journal of Development Studies 44(8): 1145-1168, https://doi.org/10.1080/00220380802242404

van den Boogaard, V. (2020a) 'Equity implications of the co-provision of public education in Sierra Leone', NORRAG Special Issue: Domestic Financing: Tax and Education: 5

(2020b) Informal revenue generation and the state: Evidence from Sierra Leone, PhD thesis, University of Toronto, https://tspace.library.utoronto.ca/handle/1807/103437?mode=full 
Prichard, W., Beach, R. and Mohiuddin, F. (2020) Strengthening Tax-Accountability Links: Fiscal Transparency and Taxpayer Engagement in Ghana and Sierra Leone, ICTD Working Paper 114, Brighton: Institute of Development Studies, https://doi.org/10.19088/ICTD.2020.002

and Jibao, S. (2019) 'Informal taxation in Sierra Leone: Magnitudes, perceptions and implications', African Affairs 118(471): 259-284

and Santoro, F. (2021) Explaining informal taxation and revenue generation: Evidence from south-central Somalia, ICTD Working Paper, Brighton: Institute of Development Studies

Van der Windt, P., Humphreys, M., Medina, L., Timmons, J. and Voors, M. (2018) 'Citizen attitudes toward traditional and state authorities: Substitutes or complements?', Comparative Political Studies 52(12): 1810-1840

Van Domelen, J. (2003) Social capital in the operations and impacts of social investment funds, World Bank, https://cpb-us-

e1.wpmucdn.com/sites.northwestern.edu/dist/6/2076/files/2020/03/How_Political_Insi ders_Lose_Out_When_International_Aid_Underperforms_WorkingPaper.pdf

Varming, K. S. (2019) 'Ideological Taxation: Hybridity and Images of State in Puntland, Somalia', Bildhaan: An International Journal of Somali Studies 19(5)

Vivalt, E. (2020) 'How Much Can We Generalize From Impact Evaluations?', Journal of the European Economic Association 18(6): 3045-3089, https://doi.org/10.1093/jeea/jvaa019

Walker, M. (2018) Informal taxation and cash transfers: Experimental evidence from Kenya, Working Paper C-89334-KEN-1), International Growth Center

- (2017) Informal Taxation and Cash Transfers: Experimental Evidence from Kenya [Working Paper — need permission to cite]

Walker, T. (2011) Community Involvement in Public Goods Provision: Evidence From a Field Experiment in Ghana, Working Paper No. 11/0069, International Growth Centre

Wang, S. and Angang, H. (2001) The Chinese economy in crisis: State capacity and tax reform, M.E. Sharpe

Weber, M. (1962) Basic Concepts in Sociology_Max Weber_Google Books, Citadel Press, https://books.google.ca/books?id=G_QNAQAAIAAJ\&source=gbs_book_other_versio ns

White, H. (2002) 'Social funds: A review of the issues', Journal of International Development 14: $605-610$

(1999) 'Politicising development? The role of participation in the activities of aid agencies' in K. Gupta (ed), Foreign aid: New perspectives 68: 109-126, Springer

Menon, R. and Weddington, H. (2018) Community-driven development: Does it build social cohesion or infrastructure? A mixed-method evidence synthesis, Technical Report Working Paper 30, International Initiative for Impact Evaluation (3ie) 
Winters, M. S., Dietrich, S. and Mahmud, M. (2018) 'Aiding the Virtuous Circle? International Development Assistance and Citizen Confidence in Government in Bangladesh', Journal of Intervention and Statebuilding 12(4): 468-483, https://doi.org/10.1080/17502977.2018.1520954

Wong, S. (2012) What have been the impacts of World Bank community-driven development programs? CDD impact evaluation review and operational and research implications, Working Paper No. 69541, The World Bank

and Guggenheim, S. (2018) Community-driven development: Myths and realities, Policy Research Working Paper No. WPS8435, The World Bank

World Bank (2020) Somalia urbanization review: Fostering cities as anchors of development, World Bank

(2017) Mobilizing Domestic Revenue to Rebuild Somalia, Somali Economic Update, World Bank

(2015) In Africa, community-driven development tackles fragility from the ground up, World Bank, https://www.worldbank.org/en/news/feature/2015/06/11/in-africacommunity-driven-development-tackles-fragility-from-the-ground-up

(2010) Somalia-Community driven recovery and development project: Restructuring, Project Paper No. 55282, World Bank

(2009) Piloting community driven development in Somalia: Rebuilding communities after a legacy of conflict, News and Press Release, World Bank, https://reliefweb.int/report/somalia/piloting-community-driven-development-somaliarebuilding-communities-after-legacy

(2001) Dynamic risk management and the poor: Developing a social protection strategy for Africa, World Bank, http://documents1.worldbank.org/curated/en/914511468740187757/pdf/multiOpage.p df

Zartman, I. (ed) (1995) Collapsed States: The Disintegration and Restoration of Legitimate Authority, Lynne Rienner

Ziblatt, D. (2008) 'Why Some Cities Provide More Public Goods than Others: A Subnational Comparison of the Provision of Public Goods in German Cities in 1912', Studies in Comparative International Development 43(3-4): 273-289, https://doi.org/10.1007/s12116-008-9031-y

Zoppi, M. (2017) 'Somalia: Federating citizens or clans? Dilemmas in the quest for stability', Journal of Contemporary African Studies 36(1): 54-70 